\title{
Titanium dioxide nanoparticles: a review of current toxicological data
}

\author{
Hongbo Shi ${ }^{1 \dagger}$, Ruth Magaye ${ }^{1 \dagger}$, Vincent Castranova ${ }^{2}$ and Jinshun Zhao ${ }^{1 *}$
}

\begin{abstract}
Titanium dioxide $\left(\mathrm{TiO}_{2}\right)$ nanoparticles (NPs) are manufactured worldwide in large quantities for use in a wide range of applications. $\mathrm{TiO}_{2}$ NPs possess different physicochemical properties compared to their fine particle (FP) analogs, which might alter their bioactivity. Most of the literature cited here has focused on the respiratory system, showing the importance of inhalation as the primary route for $\mathrm{TiO}_{2} \mathrm{NP}$ exposure in the workplace. $\mathrm{TiO}_{2} \mathrm{NPs}$ may translocate to systemic organs from the lung and gastrointestinal tract (GIT) although the rate of translocation appears low. There have also been studies focusing on other potential routes of human exposure. Oral exposure mainly occurs through food products containing $\mathrm{TiO}_{2} \mathrm{NP}$-additives. Most dermal exposure studies, whether in vivo or in vitro, report that $\mathrm{TiO}_{2} \mathrm{NPs}$ do not penetrate the stratum corneum (SC). In the field of nanomedicine, intravenous injection can deliver $\mathrm{TiO}_{2}$ nanoparticulate carriers directly into the human body. Upon intravenous exposure, $\mathrm{TiO}_{2} \mathrm{NPs}$ can induce pathological lesions of the liver, spleen, kidneys, and brain. We have also shown here that most of these effects may be due to the use of very high doses of $\mathrm{TiO}_{2} \mathrm{NPs}$. There is also an enormous lack of epidemiological data regarding $\mathrm{TiO}_{2} \mathrm{NPs}$ in spite of its increased production and use. However, long-term inhalation studies in rats have reported lung tumors. This review summarizes the current knowledge on the toxicology of $\mathrm{TiO}_{2} \mathrm{NPs}_{\mathrm{s}}$ and points out areas where further information is needed.
\end{abstract}

Keywords: Titanium dioxide, Nanoparticle, Toxicology, Toxicokinetics, Acute toxicity, Chronic toxicity, Genotoxicity, Reproductive toxicity, Carcinogenicity

\section{Introduction}

With the development of nanotechnology, there has been a tremendous growth in the application of NPs for drug delivery systems, antibacterial materials, cosmetics, sunscreens, and electronics [1,2]. In October 2011 the European Union defined nanomaterials as a natural, incidental or manufactured material containing particles, in an unbound state or as an aggregate or agglomerate; where $50 \%$ or more of the particles exhibited, one or more external dimensions in the size range 1-100 nm [3]. Others have defined NPs as objects with at least one of their three dimensions in the range of $1-100 \mathrm{~nm}$ $[4,5]$. NPs generally possess dramatically different physicochemical properties compared to fine particles (FPs) of the same composition. The smaller size of NPs

\footnotetext{
* Correspondence: zhaojinshun@nbu.edu.cn

${ }^{\dagger}$ Equal contributors

'Public Health Department of Medical School, Zhejiang Provincial Key Laboratory of Pathological and Physiological Technology, Ningbo University, Ningbo, Zhejiang Province 315211, P. R. China

Full list of author information is available at the end of the article
}

ensures that a large portion of atoms will be on the particle surface. Since surface properties, such as energy level, electronic structure, and reactivity are quite different from interior states, the bioactivity of NPs will likely differ from that of the fine size analogue.

Traditionally, $\mathrm{TiO}_{2}$ FPs have been considered as poorly soluble, low toxicity particles [6,7]. Due to this reason, they have been traditionally used as a "negative control" in many in vitro and in vivo particle toxicological studies [8]. However, this view was challenged after lung tumors developed in rats after two years of exposure to high concentrations of fine $\mathrm{TiO}_{2}$ particles [9]. The International Agency for Research on Cancer (IARC), therefore, has classified $\mathrm{TiO}_{2}$ as a Group 2B carcinogen (possibly carcinogenic to humans) [10]. However, the tumorigenic effect of fine $\mathrm{TiO}_{2}$ has been questioned and attributed to lung overload rather than specific carcinogenicity of fine $\mathrm{TiO}_{2}$ [7]. In recent years, $\mathrm{TiO}_{2}$ NPs have been widely used in industrial and consumer products due to their stronger catalytic activity when compared to 
$\mathrm{TiO}_{2}$ FPs. This increase in catalytic activity has been attributed to their smaller sizes, which has allowed for larger surface area per unit mass. Concerns have been raised that these same properties of $\mathrm{TiO}_{2}$ NPs may present unique bioactivity and challenges to human health $[11,12]$. The rapid growth in the number of published studies confirms that there is a high level of interest concerning the safety of $\mathrm{TiO}_{2}$ NPs. Different animal models employing multiple exposure routes of administration, including inhalation, dermal exposure, intratracheal instillation, oral gavage, intragastric, intraperitoneal or intravenous injection have been intensively used in these studies. Studies have revealed that $\mathrm{TiO}_{2} \mathrm{NPs}$ are more toxic than FPs $[8,13,14]$. Oberdorster et al. [15] reported that $\mathrm{TiO}_{2}$ NPs $(21 \mathrm{~nm})$ caused a greater pulmonary inflammatory response than $\mathrm{TiO}_{2}$ at same mass burden, with greater amounts of $\mathrm{TiO}_{2}$ NPs entering the alveolar interstitium in the lungs. Sager et al. [16] have reported similar results after intra-tracheal instillation of well-dispersed suspensions of $\mathrm{TiO}_{2}$ NPs (80/20 anatase/ rutile; $21 \mathrm{~nm}, \mathrm{P}-25)$ and $\mathrm{TiO}_{2}$ FPs (100\% rutile; $\left.1 \mu \mathrm{m}\right)$ in rats. On an equal mass burden, nano $\mathrm{TiO}_{2}$ was 40 fold more potent in inducing lung inflammation and damage at 1 and 42 days post-exposure than fine $\mathrm{TiO}_{2}$. However, respective potencies were not significantly different when dose was expressed on the basis of total surface area of particles delivered to the lung.

Wide application of $\mathrm{TiO}_{2}$ NPs confers substantial potential for human exposure and environmental release, which inevitably allows for a potential health risk to humans, livestock, and the eco-system [17]. This paper will focus mainly on current knowledge concerning the toxicology of $\mathrm{TiO}_{2}$ NPs. Studies done with mixtures of $\mathrm{TiO}_{2}$ NPs with other compounds and studies that have focused on aquatic ecosystems and the environment will not be discussed in this review. Even though the nanoparticle (NP) size has recently been defined as $<100 \mathrm{~nm}$, we have also included some studies that have defined particle sizes that are $>100 \mathrm{~nm}$ as NPs. The molecular mechanisms of carcinogenesis will also be reviewed, to address health concerns regarding carcinogenesis due to particle exposure.

\section{Chemical and physical properties}

Titanium (Ti), the ninth most abundant element in the earth's crust, is widely distributed. The average concentration of $\mathrm{Ti}$ in the earth's crust is $4400 \mathrm{mg} / \mathrm{kg}$. Owing to its great affinity for oxygen and other elements, $\mathrm{Ti}$ does not exist in the metallic state in nature. The most common oxidation state of $\mathrm{Ti}$ is ${ }^{+} 4$, but ${ }^{+} 3$ and ${ }^{+} 2$ states also exist. Metallic $\mathrm{Ti}, \mathrm{TiO}_{2}$, and $\mathrm{TiCl}_{4}$ are the compounds most widely used in industry. $\mathrm{TiO}_{2}$ (CAS-No. 13463-67-7), also known as titanium (IV) oxide, titanic acid anhydride, titania, titanic anhydride, or Ti white, is the naturally occurring oxide of $\mathrm{Ti} . \mathrm{TiO}_{2}$ is a white noncombustible and odorless powder with a molecular weight of $79.9 \mathrm{~g} / \mathrm{mol}$, boiling point of $2972^{\circ} \mathrm{C}$, melting point of $1843^{\circ} \mathrm{C}$, and relative density of $4.26 \mathrm{~g} / \mathrm{cm}^{3}$ at $25^{\circ} \mathrm{C}$. $\mathrm{TiO}_{2}$ is a poorly soluble particulate that has been widely used as a white pigment. Anatase and rutile are two crystal structures of $\mathrm{TiO}_{2}$, with anatase being more chemically reactive $[18,19]$. For example, Sayes et al. [19] reported that NPs (80/20; anatase/rutile, 3-5 nm; $100 \mu \mathrm{g} / \mathrm{ml}$ ) generated 6 fold more reactive oxygen species (ROS) than rutile after UV irradiation. Indeed, anatase generates ROS when irradiated by UV light [19]. It has been suggested that $\mathrm{TiO}_{2}$ anatase has a greater toxic potential than $\mathrm{TiO}_{2}$ rutile $[20,21]$. However, anatasegenerated ROS does not occur under ambient light conditions. $\mathrm{TiO}_{2}$ NPs are normally a mixture of anatase and rutile crystal forms. The principal parameters of particles affecting their physicochemical properties include shape, size, surface characteristics and inner structure. $\mathrm{TiO}_{2}$ FPs (the rutile form) are believed to be chemically inert. However, when the particles become progressively smaller, their surface areas, in turn, become progressively larger, and researchers have also expressed concerns about the harmful effects of $\mathrm{TiO}_{2}$ NPs on human health associated with the decreased size [22,23]. Surface modification such as coating, influences the activity of $\mathrm{TiO}_{2}$ NPs. For example, diminished cytotoxicity was observed when the surface of $\mathrm{TiO}_{2}$ NPs was modified by a grafting-to polymer technique combining catalytic chain transfer and thiol-ene click chemistry [24]. Another study confirmed the effect of surface coating on biological response endpoints of $\mathrm{TiO}_{2}$ NPs [25].

In conclusion, $\mathrm{TiO}_{2}$ NPs possess different physicochemical properties compared to $\mathrm{TiO}_{2}$ FPs. These properties likely influence bioactivity. Based on this fact, adverse health effects and environmental bio-safety of $\mathrm{TiO}_{2}$ NPs should be carefully evaluated even if $\mathrm{TiO}_{2}$ FPs have been demonstrated to have low toxicity. It is recommended that researchers carefully characterize the physicochemical properties of $\mathrm{TiO}_{2}$ NPs not only in the bulk form but also as delivered to the test system.

\section{Uses}

$\mathrm{TiO}_{2}$ is a white pigment and because of its brightness and very high refractive index it is most widely used. Approximately four million tons of this pigment are consumed annually worldwide [26]. In addition, $\mathrm{TiO}_{2}$ accounts for $70 \%$ of the total production volume of pigments worldwide [27], and is in the top five NPs used in consumer products [28]. $\mathrm{TiO}_{2}$ can be used in paints, coatings, plastics, papers, inks, medicines, pharmaceuticals, food products, cosmetics, and toothpaste [29-31]. It can even be used as a pigment to whiten skim milk. $\mathrm{TiO}_{2}$ NPs are also used in sunscreens [32]. In addition, 
$\mathrm{TiO}_{2}$ has long been used as a component for articulating prosthetic implants, especially for the hip and knee $[33,34]$. These implants occasionally fail due to degradation of the materials in the implant or a chronic inflammatory response to the implant material [35].

Currently, $\mathrm{TiO}_{2}$ NPs are produced abundantly and used widely because of their high stability, anticorrosive and photocatalytic properties [4]. Some have attributed this increased catalytic activity to $\mathrm{TiO}_{2} \mathrm{NPs}$ to their high surface area, while others attribute it to $\mathrm{TiO}_{2} \mathrm{NPs}$ being predominantly anatase rather than rutile $[18,19] . \mathrm{TiO}_{2}$ NPs can be used in catalytic reactions, such as semiconductor photocatalysis, in the treatment of water contaminated with hazardous industrial by-products [36], and in nanocrystalline solar cells as a photoactive material [37]. Industrial utilization of the photocatalytic effect of $\mathrm{TiO}_{2}$ NPs has also found its way into other applications, especially for self-cleaning and anti-fogging purposes such as self-cleaning tiles, self-cleaning windows, selfcleaning textiles, and anti-fogging car mirrors [38]. In the field of nanomedicine, $\mathrm{TiO}_{2} \mathrm{NPs}$ are under investigation as useful tools in advanced imaging and nanotherapeutics [37]. For example, $\mathrm{TiO}_{2} \mathrm{NPs}$ are being evaluated as potential photosensitizers for use in photodynamic therapy (PDT) [39]. In addition, unique physical properties make $\mathrm{TiO}_{2}$ NPs ideal for use in various skin care products. Nano-preparations with $\mathrm{TiO}_{2}$ NPs are currently under investigation as novel treatments for acne vulgaris, recurrent condyloma accuminata, atopic dermatitis, hyperpigmented skin lesions, and other nondermatologic diseases [40]. $\mathrm{TiO}_{2}$ NPs also show antibacterial properties under UV light irradiation $[37,41]$.

\section{Exposure routes and limits}

Ti occurs in tissues of normal animals but only in trace amounts [42]. There is no evidence of Ti being an essential element for human beings or animals. The Ti compound concentration in drinking water is generally low. A typical diet may contribute $300-400 \mu \mathrm{g} /$ day. $\mathrm{TiO}_{2}$ particles are produced and used in varying particle size fractions including fine (approximately 0.1-2.5 $\mu \mathrm{m}$ ) and nanosize $(<0.1 \mu \mathrm{m}$, primary particles $)$ [43]. Human exposure to $\mathrm{TiO}_{2}$ NPs may occur during both manufacturing and use. $\mathrm{TiO}_{2}$ NPs can be encountered as aerosols, suspensions or emulsions. The major routes of $\mathrm{TiO}_{2}$ $\mathrm{NP}$ exposure that have toxicological relevance in the workplace are inhalation and dermal exposure. It is reported that more than 150 items of "manufactureridentified nanotechnology-based consumer products would have long term dermal contact. The most common nanomaterials found in consumer products for dermal application are $\mathrm{TiO}_{2}$ NPs [2]. $\mathrm{TiO}_{2}$ NPs are also widely used for toothpaste, food colorants and nutritional supplements. Therefore, oral exposure may occur during use of such products. In a recent study by Weir et al. [44] found that candies, sweets and chewing gums contained the highest amount of $\mathrm{TiO}_{2}$ in the scale of $<100 \mathrm{~nm}$. In nanomedicine, intravenous or subcutaneous injection of $\mathrm{TiO}_{2}$ nano particulate carriers is a unique way to deliver $\mathrm{TiO}_{2}$ NPs into the human body [45]. In cases where $\mathrm{TiO}_{2}$ NPs were embedded into products such as household paint, they have been shown to be less harmful, unless liberated by sanding [46].

The United States Food and Drug Administration (FDA) approved $\mathrm{TiO}_{2}$ as a food color additive with the stipulation that the additive was "not to exceed $1 \%$ by body weight (BW) ". $\mathrm{TiO}_{2}$ was also approved by the United States FDA as a "food contact substance" in food packaging [47]. Due to the differences in the physicochemical properties of $\mathrm{TiO}_{2}$ FPs and NPs exposure and toxicity information for $\mathrm{TiO}_{2} \mathrm{NPs}$ is needed to develop exposure limits specific for $\mathrm{TiO}_{2}$ NPs.

The American Conference of Governmental Industrial Hygienists (ACGIH) has assigned $\mathrm{TiO}_{2}$ FPs (total dust) a threshold limit value (TLV) of $10 \mathrm{mg} / \mathrm{m}^{3}$ as a time weighted average (TWA) for a normal $8 \mathrm{~h}$ workday and a $40 \mathrm{~h}$ workweek [48]. Permissible exposure limit (PEL)TWA of the Occupational Safety \& Health Administration (OSHA) for $\mathrm{TiO}_{2}$ FPs is $15 \mathrm{mg} / \mathrm{m}^{3}$ [49]. In November 2005, the United States National Institute for Occupational Safety and Health (NIOSH) proposed a recommended exposure limit (REL) for $\mathrm{TiO}_{2} \mathrm{NPs}$ at $0.3 \mathrm{mg} / \mathrm{m}^{3}$, which was 10 times lower than the REL for $\mathrm{TiO}_{2}$ FPs [50]. In the "Risk Assessment of Manufactured Nanomaterials $\mathrm{TiO}_{2}$ Executive Summary" compiled by the New Energy and Industrial Technology Development Organization (NEDO) in Japan, the acceptable exposure concentration of $\mathrm{TiO}_{2}$ NPs was estimated to be $1.2 \mathrm{mg} / \mathrm{m}^{3}$ as a TWA for a $8 \mathrm{~h}$ workday and a $40 \mathrm{~h}$ workweek [51]. The no observed adverse effect level (NOAEL) for P25 $\mathrm{TiO}_{2}$ was extrapolated to be around $1.2 \mathrm{mg} / \mathrm{m}^{3}$ respirable dust as TWA in the case of a hypothetical 8-hour day, 5-day working week.

Worker exposure is possible during the handling process. However, a study showed that exposure during handling, transferring, bagging, mixing, and oven cleaning was well below the currently established limits [52]. Lee et al. [53] monitored the occupational exposure at workplaces in Korea that manufacture $\mathrm{TiO}_{2}$ NPs. Personal sampling, area monitoring, real-time monitoring, and dust monitoring were conducted at workplaces where the workers handled $\mathrm{TiO}_{2}$ NPs. The gravimetric concentrations of $\mathrm{TiO}_{2}$ NPs ranged from 0.10 to $4.99 \mathrm{mg} / \mathrm{m}^{3}$. The particle numbers concentration at the $\mathrm{TiO}_{2}$ NPs manufacturing workplaces ranged from 11,418 to 45,889 particles $/ \mathrm{cm}^{3}$ with a size range of $15-710 \mathrm{~nm}$. Occupational exposure to engineered nanomaterial oxides could be effectively reduced by proper local exhaust 
ventilation (LEV), filtration, containment, and good work practices [54].

In conclusion, the primary route of occupational exposure for $\mathrm{TiO}_{2}$ NPs is inhalation. Consumer inhalation is also possible during application of antimicrobial spray containing $\mathrm{TiO}_{2}$ NPs. Oral exposure may occur through food products which contain $\mathrm{TiO}_{2} \mathrm{NP}$-additives. Dermal contact may occur through applications of cosmetics and sunscreens. Intravenous injection of $\mathrm{TiO}_{2}$ NPs could occur in medical application. Further information is needed regarding airborne exposure levels of $\mathrm{TiO}_{2}$ NPs in the workplace and what processes are associated with high NP releases. It is recommended that workplace exposure assessment evaluate airborne mass particle concentrations, particle counts, and size distribution of $\mathrm{TiO}_{2}$ NPs. To date, the consumer or environmental exposure data for $\mathrm{TiO}_{2}$ NPs is inadequate. Therefore, it is recommended that exposure assessment be made throughout the life cycle of products containing $\mathrm{TiO}_{2}$ NPs.

\section{Toxicokinetics}

Toxicokinetics is the description of the rate at which a substance $\left(\mathrm{TiO}_{2} \mathrm{NPs}\right)$ enters the body through different exposure routes and its fate after entering the body. The level or concentration of $\mathrm{TiO}_{2} \mathrm{NPs}$ in the body system depends on the rate (or kinetic) of absorption, distribution, metabolism, and excretion of $\mathrm{TiO}_{2}$ NPs. These processes may occur after exposure through inhalation, ingestion, dermal contact, and intraperitioneal or intravenous injection. The toxicokinetics of $\mathrm{TiO}_{2} \mathrm{NPs}$ will be discussed in terms of the different kinetics.

\section{Absorption}

Following deposition of NPs at the initial site of exposure, absorption and translocation to systemic sites is a critical step in toxicokinetics. It is often defined as migration of the NP to distal organs. For instance, at what rate are $\mathrm{TiO}_{2}$ NPs absorbed through the GIT, the skin (dermal), pulmonary system, or other exposure sites, as with intravenous exposure, intra-peritoneal exposure, or subcutaneous exposure.

\section{Gastrointestinal absorption}

GIT may be an important absorption route for $\mathrm{TiO}_{2}$ NPs since drug carriers, food products, water and liquid beverages may contain $\mathrm{TiO}_{2}$ NPs $[55,56]$. In the field of nanomedicine, the GIT uptake of NPs has been the subject of recent efforts to develop effective carriers that enhance the oral uptake of drugs and vaccines [57]. $\mathrm{TiO}_{2}$ FPs (rutile; $500 \mathrm{~nm} ; 12.5 \mathrm{mg} / \mathrm{kg}$ ) have been shown to systemically translocate to other tissues from the rat GIT [58]. $\mathrm{TiO}_{2}$ particle uptake in GIT was proposed to take place via the peyers patches, due to the high presence of $\mathrm{TiO}_{2}$ FPs in the lymphoid tissues. $\mathrm{TiO}_{2} \mathrm{NPs}$ have also been shown to be absorbed from the GIT (25, 80, and $155 \mathrm{~nm} ; 5 \mathrm{~g} / \mathrm{kg} \mathrm{BW;} \mathrm{single} \mathrm{oral} \mathrm{dose;} \mathrm{mice)} \mathrm{[59].}$ $\mathrm{TiO}_{2}$ NPs may be absorbed through the GIT through the lymphoid tissues surrounding it. However, since the dose used in this study was high, the extent of absorption under relevant human exposures is in question.

\section{Dermal absorption}

Dermal absorption of $\mathrm{TiO}_{2}$ NPs is of interest because many consumer products, such as cosmetics and sunscreens may contain $\mathrm{TiO}_{2}$ NPs. The outer skin of human beings consists of a tough layer of SC that is difficult for inorganic particles to penetrate. Theoretically, only those materials with an appropriate octanol/water partition coefficient and low molecular weight $(<\mathrm{ca}$. 500) should penetrate the intact human skin through the SC. Therefore, it is unlikely that inorganic particles would penetrate the intact skin under normal conditions [60]. It is worth noting that although cosmetics and sunscreens containing $\mathrm{TiO}_{2}$ are normally used on intact skin. Slight injuries to skin can occur under certain circumstances, such as physical force or sunburn. Thus, skin penetration studies of $\mathrm{TiO}_{2}$ particles are usually investigated in vivo and in vitro with both intact skin and stripped skin which mimics an injured skin [60]. Several studies have investigated dermal penetration by $\mathrm{TiO}_{2} \mathrm{NPs}$. Some of these studies [61-65] concluded that $\mathrm{TiO}_{2}$ NPs did not penetrate the intact human skin. Senzui et al. [60] investigated the skin penetration of four types of rutile $\mathrm{TiO}_{2}$ particles (35 nm non-coated, $35 \mathrm{~nm}$ coated, 100 $\mathrm{nm}$ almina and silicon coated, and $250 \mathrm{~nm}$ non-coated) in intact or stripped skin of Yucatan micropigs in vitro (2 $\mu$ l suspension, $1 \mathrm{~cm}^{2}$ skin area). Results demonstrated that $\mathrm{TiO}_{2}$ particles did not penetrate viable skin, even though the particle size was less than $100 \mathrm{~nm}$ and the SC was damaged. Further observation with scanning electron microscopy (SEM) showed that although some $\mathrm{TiO}_{2}$ particles had lodged into vacant hair follicles, it did not penetrate the dermis or viable epidermis. Similar results were obtained previously by Lademann et al. [66], showing no penetration into live tissue. Tape stripping with adhesive tape is a widely accepted method to examine the localization and distribution of substances within the SC [67]. Tan et al. [68] investigated a sunscreen containing $8 \% \mathrm{TiO}_{2}$ NPs $(10-50 \mathrm{~nm})$ applied twice a day for 2-6 weeks on the skin of human volunteers (age range 59-82 yr) and evaluated the epidermal penetration of $\mathrm{TiO}_{2}$ NPs into the epidermis using tape stripping. They found that levels of $\mathrm{TiO}_{2}$ NPs in the epidermis and dermis of subjects who applied $\mathrm{TiO}_{2}$ NPs to their skin were higher than the levels of $\mathrm{TiO}_{2} \mathrm{NPs}$ found in controls. However, they pointed out that a larger sample size would be necessary to establish if this difference was 
significant. It is also worth noting that the morphology of the SC differs among different age groups, which also influences the results. Bennat and Müller-Goymann [69] showed that $\mathrm{TiO}_{2}$ NPs penetrated hairy skin when applied as an oil-in-water emulsion. They evaluated skin penetration of $\mathrm{TiO}_{2}$ NPs $(20 \mathrm{~nm}$, formulations with $5 \%$ $\mathrm{TiO}_{2} \mathrm{NPs}$ ) applied to human skin either as an aqueous suspension or as oil-in-water emulsion using the tape stripping method. The results suggest that $\mathrm{TiO}_{2}$ NPs maybe able to penetrate the surface through hair follicles or pores. However, no details were given regarding the fate of the particles that did penetrate. $\mathrm{TiO}_{2} \mathrm{NPs}$ were also found to have no skin carcinogenesis promoting effects due to lack of penetration through the epidermis [70,71] (details given in the section on carcinogenecity). Another study utilizing the time of flight secondary ion mass spectrometry (TOF-SIMS) showed the presence of silica coated $\mathrm{TiO}_{2} \mathrm{NPs}$ (rutile; 14-16 nm) within epidermis and superficial dermis [72]. They concluded that ultraviolet-B (UVB) damaged skin (pigs; UVB sunburn; $250 \mu \mathrm{l}$ of each sunscreen formulation) slightly enhanced $\mathrm{TiO}_{2}$ NPs penetration in sunscreen formulations but they did not detect transdermal absorption.

Similar results were obtained in an in vitro study [73]. In this study the cutaneous penetration and localization of $\mathrm{TiO}_{2} \mathrm{NPs}(\geq 20 \mathrm{~nm}$ primary size; $24 \mathrm{~h}$ sunscreen application), included in a sunscreen was evaluated in intact, damaged, irradiated, and damaged/irradiated pig skin. Quantitative analysis was done using an inductively coupled plasma-mass spectrometry, qualitative analysis done using transmission electron microscopy (TEM) and elemental identity of the NPs was evaluated by TEM-coupled Energy Dispersive X-ray (TEM-EDX) analysis. In intact and damaged/irradiated skins, $102.35 \pm 4.20 \%$ and $102.84 \pm 5.67 \%$ of the $\mathrm{Ti}$ was deposited, respectively, at the surface and SC, whereas only $0.19 \pm 0.15 \%$ and $0.39 \pm 0.39 \%$ were found in the viable epidermis and dermis. No $\mathrm{Ti}$ was detected in the receptor fluid. TEM-EDX analysis confirmed the presence of $\mathrm{TiO}_{2} \mathrm{NPs}$ at the SC surface, as already characterized in the sunscreen formulation. They concluded that $\mathrm{TiO}_{2} \mathrm{NPs}$ included in a sunscreen remain in the uppermost layers of the SC, in intact skin, compromised skin, or skin exposed to simulated solar radiation. Filipe et al. [74] also noted that in normal human skin $\mathrm{TiO}_{2} \mathrm{NPs}$ were unlikely to penetrate the $\mathrm{SC}$ towards the underlying keratinocytes (coated $20 \mathrm{~nm} ; 2$ and $48 \mathrm{~h}$ ).

One study found that $\mathrm{TiO}_{2}$ NPs could possibly penetrate the SC depending on the particle coating and skin with or without hair. However, their claims may be questioned, due to lack of data on systemic evaluation of the NPs that did penetrate the SC. Apart from this, it should be noted that most other studies reported that $\mathrm{TiO}_{2}$ NPs did not penetrate into live tissue from the deposition sites. Therefore, it can be concluded that $\mathrm{TiO}_{2}$ NPs are not systemically available to a significant extant after dermal exposure.

\section{Pulmonary absorption}

The pulmonary system consists of the upper respiratory tract (nose and nasal passages, paranasal sinuses and pharynx) and the lower respiratory tract (larynx, trachea, bronchi and lungs). Here we include studies done through inhalation, intratracheal instillation and intranasal (oro-pharyngeal) exposure.

Inhalation exposure Inhalation is one of the major routes for $\mathrm{TiO}_{2}$ NPs to gain entry into the human body especially in occupational settings. Numerous studies have used inhalation as the exposure route to determine the toxicokinetics and cyto- or genotoxicity of $\mathrm{TiO}_{2}$ NPs. The limit for FPs in the air is $50 \mu \mathrm{g} / \mathrm{m}^{3}$ for an average human of $70 \mathrm{~kg}$ [75].

Figure 1 shows the particulate distribution of $\mathrm{TiO}_{2}$ particles by size through the different regions of the respiratory tract after inhalation.

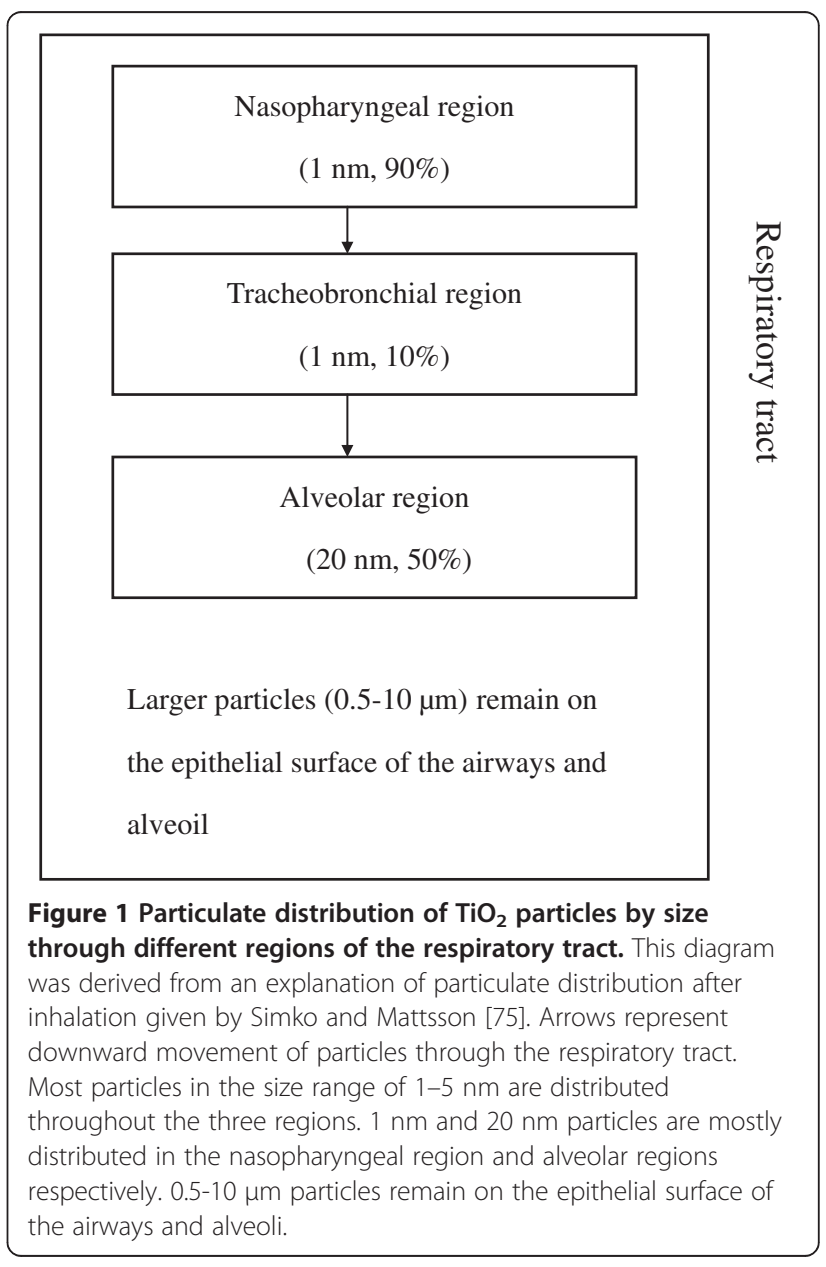


Human data related to absorption through inhalation of $\mathrm{TiO}_{2}$ NPs are currently not available. However, there are quantitative data available from rodent studies [76]. Muhlfeld et al.[77] suggested that a small fraction of $\mathrm{TiO}_{2}$ NPs (20 nm; 1 and $24 \mathrm{~h}$; dose ranges differed according to compartment size) are transported from the airway lumen of adult male $\mathrm{WKY} / \mathrm{NCrl} \mathrm{BR}$ rats to the interstitial tissue and subsequently released into the systemic circulation.

Intratracheal instillation Intratracheal instillation is a technique where single or repeated doses of precise volumes of particulate suspensions are administered directly to the lungs. It should be noted that there may be significant differences in distribution, clearance, and retention of materials administered by intratracheal instillation, especially at high bolus doses, compared to low dose rate inhalation. Although, inhalation studies are considered to be the gold standard, data from intratracheal instillation studies can be used for hazard assessment [78]. Sager et al. [16] reported that a significant portion of deposited $\mathrm{TiO}_{2}$ NPs $(21 \mathrm{~nm})$ migrated to the interstitial space by 42 days after intratracheal instillation in rats. $\mathrm{TiO}_{2}$ NPs migrated to the alveolar interstitium to a significantly greater extent than $\mathrm{TiO}_{2}$ FPs after either inhalation exposure [15] or intratracheal instillation [16]. Another study found that at 28 days after instillation, a small fraction of pulmonary $\mathrm{TiO}_{2}$ NPs were able to access the blood circulation and reach extrapulmonary tissues such as liver and kidneys [79].

Intranasal exposure Breathing is mostly done through the nose, and is termed nasal breathing. The nasal cavity has two segments, the respiratory segment and the olfactory segment. The respiratory segment is lined with ciliated pseudostratified columnar epithelium, it has a very vascularized lamina propria allowing the venous plexuses of the conchal mucosa to engorge with blood, restricting airflow and causing air to be directed to the other side of the nose. The olfactory segment is lined with the olfactory epithelium, which contains receptors for the sense of smell. Olfactory mucosal cell types include bipolar neurons, supporting (sustentacular) cells, basal cells, and Bowman's glands. The axons of the bipolar neurons form the olfactory nerve (cranial nerve I) and enter the brain through the cribiform plate. Studies by Wang et al. [80,81] on murine brain reported that intra-nasally instilled $\mathrm{TiO}_{2}$ NPs (80 nm rutile, 155 $\mathrm{nm}$ anatase; $500 \mu \mathrm{g} / \mathrm{ml} ; 2,10,20$, and 30 days) can be taken up by sensory nerves and translocate to the brain.

Even though the inhalation, intratracheal instillation and intranasal studies in regards to pulmonary absorption are few they suggest that $\mathrm{TiO}_{2}$ NPs can translocate from the lung into the circulatory system to systemic tissue and from the nasal cavity into sensory nerves to the nervous system. Available data suggest that the rate of NP migration to the circulatory system is low.

\section{Distribution}

After the initial absorption of $\mathrm{TiO}_{2} \mathrm{NPs}$, the systemic circulation can distribute the particles to all organs and tissues in the body. After $\mathrm{TiO}_{2}$ NPs reach the systemic circulation, these particles potentially interact with plasma-proteins [82], coagulation factors, platelets and red or white blood cells. The binding to plasma components may have a substantial effect on the distribution, metabolism, and excretion of the NPs [55]. Binding to plasma components might neutralize or mask the adverse effects of $\mathrm{TiO}_{2}$ NPs in the systemic circulation. Therefore the biokinetics of the engineered NPs is also dependent on the local corona environment [83]. They might also contribute to disturbances in the corona environment as noted by Mikkelsen et al. [84]. In this study repeated exposure to $\mathrm{TiO}_{2}$ NPs (12-21.6 nm; 0.5 $\mathrm{mg} / \mathrm{kg} \mathrm{BW}$ ) was associated with modest plaque progression in ApoE (-/-) mice. $\mathrm{TiO}_{2}$ NPs (20-30 nm, anatase 99.9\%; $5 \mu \mathrm{g} / \mathrm{ml}$ ) were also able to penetrate human red blood cells [85]. This cellular uptake of $\mathrm{TiO}_{2}$ NPs might not involve endocytosis, since erythrocytes do not have phagocytic receptors. These results imply that $\mathrm{TiO}_{2}$ NPs might be able to cross the cell membrane by processes other than phagocytosis and endocytosis. Diffusion or adhesive interactions may also play certain roles in this cellular uptake of $\mathrm{TiO}_{2}$ NPs [55,86]. Wick et al. [87] used the ex vivo human placental perfusion model to determine whether NPs can cross the blood-placenta barrier and whether this process is size dependent. Fluroescent polystyrene particles were used as a model NP. They found that fluorescent polystyrene particles with diameter up to $240 \mathrm{~nm}$ were taken up by the placenta. Earlier studies by Shimizu et al. [88] and Takeda et al. [89] had shown that subcutaneous exposure of pregnant mice to $\mathrm{TiO}_{2}$ NPs affected gene expression and genital and cranial nerve systems of the offspring. In addition, a study using inhalation exposure has shown that $\mathrm{TiO}_{2}$ NPs can also penetrate the blood placenta barrier [88-90].

Translocation refers to the way particles move from the site of absorption to other parts of the body. In humans it may occur in the alveolar region where the air-blood-barrier is approximately $2 \mu \mathrm{m}$ thick. Geiser and Kreyling [91] in their review reported that NPs including $\mathrm{TiO}_{2}$ NPs in the size range of 5-100 nm could be translocated across the air-blood-barrier. When $\mathrm{TiO}_{2}$ NPs are translocated into the blood, generally they may be retained in the liver and lymphatic system, distributed to other organs and tissues, or eliminated out of the 
body. A 3-week inhalation study using nano- and fine $\mathrm{TiO}_{2}$ particles with 3, 28, and 90 days recovery time was performed in female Wistar rats [92]. This study observed that particles were mainly found in alveolar macrophages and, to a lesser extent, in type-I pneumocytes, and this was quantified using the relative deposition index (RDI). Particle-laden cells were rarely observed inside capillaries. They concluded that there was minimal translocation of particles into the blood stream.

The interactions between $\mathrm{TiO}_{2}$ NPs and alveolar macrophages and their associated pro-inflammatory effects in relation to particle size and physico-chemical properties was investigated in vitro by Scherbart et al. [93]. NR8383 rat lung alveolar macrophages were treated (10, 20, 40, and $80 \mu \mathrm{g} / \mathrm{cm}^{2} ; 1,4$, and $24 \mathrm{~h}$ ) with $\mathrm{TiO}_{2}$ NPs (25 nm; 80/20; anatase/rutile), and FPs (250 nm). Alveolar macrophages rapidly took up both $\mathrm{TiO}_{2}$ NPs and FPs. Uptake inhibition experiments with cytochalasin D, chlorpromazine and a Fcy receptor II (FcyRII) antibody revealed that the endocytosis of $\mathrm{TiO}_{2}$ FPs by the macrophages involved actin-dependent phagocytosis and macropinocytosis as well as clathrin-coated pit formation, whereas the uptake of $\mathrm{TiO}_{2}$ NPs was dominated by FcyIIR antibody. They suggested that the contrasting alveolar macrophage responses to $\mathrm{TiO}_{2}$ NPs and FPs relate to differences in the involvement of specific uptake mechanisms.

Ferin et al. [94] monitored pulmonary retention of $\mathrm{TiO}_{2}$ FPs and NPs in rats after a single intratracheal instillation or 12 week inhalation of different sizes of $\mathrm{TiO}_{2}$ particles $(12,21,230$, and $250 \mathrm{~nm})$. They found that migration of particles to the interstitium appeared to be related to the particle size, the delivered dose, and the delivered dose rate. In addition, both acute instillation and sub-chronic inhalation studies showed that $\mathrm{TiO}_{2}$ NPs $(20 \mathrm{~nm})$ at equivalent masses access the pulmonary interstitium to a larger extent than $\mathrm{TiO}_{2}$ FPs $(250 \mathrm{~nm})$. A tracheal explants system study reported that $\mathrm{TiO}_{2}$ NPs $(21 \mathrm{~nm} ; 5 \mathrm{mg} / \mathrm{ml} ; 1 \mathrm{~h})$ enter the epithelium faster and are translocated in greater proportion to the subepithelial space compared with $\mathrm{TiO}_{2}$ FPs $(0.12 \mu \mathrm{m})$ [95]. Li et al. [79] investigated the distribution and effects of $\mathrm{TiO}_{2}$ NPs (3 nm; $13.2 \mathrm{mg} / \mathrm{kg}$; once a week for 4 weeks) in mice. They suggested that $\mathrm{TiO}_{2}$ NPs might pass through the blood-brain barrier.

Others have found that intra-nasally instilled $\mathrm{TiO}_{2}$ NPs could be translocated into the central nervous system via the olfactory nerves and cause potential brain lesions with the hippocampus being the main target [80]. These effects were mainly caused by the $155 \mathrm{~nm}$ anatase $\mathrm{TiO}_{2}$ particle, which they also defined as a NP. The same research group reported similar findings in another study (intranasal instillation; $80 \mathrm{~nm}$ rutile, 155 $\mathrm{nm}$ anatase; 30 days) [81]. The influence of intra-nasally instilled $\mathrm{TiO}_{2}$ NPs (25 nm, $80 \mathrm{~nm}$ and $155 \mathrm{~nm}$; every other day in a dose of $50 \mathrm{mg} / \mathrm{kg} \mathrm{BW}$ ) on monoaminergic neurotransmitters (norepinephrine (NE), dopamine (DA), 5hydroxytryptamine (5-HT), 5-hydroxyindole acetic acid (5-HIAA), 3, 4-dihydroxyphenylacetic acid (DOPAC), and homovanillic (HVA)) were investigated in CD female mice at 2,10,20, and 30 days post-exposure [62]. Due to the accumulation of $\mathrm{TiO}_{2} \mathrm{NPs}$ in the brain, the contents of NE and 5-HT were significantly increased after exposure to 80 $\mathrm{nm}$ and $155 \mathrm{~nm} \mathrm{TiO}_{2}$, while the concentrations of DA, DOPAC, HVA and 5-HIAA were decreased. They concluded that intranasally instilled $\mathrm{TiO}_{2}$ NPs could be translocated to and deposited in murine brain after absorption by nasal mucosa, and further influence the release and metabolism of monoaminergic neurotransmitters in the brain. Although these findings are intriguing, other studies are necessary to confirm these results.

Fabian et al. [13] investigated the tissue distribution of intravenously administered $\mathrm{TiO}_{2}$ NPs (70/30 anatase/ rutile; $20-30 \mathrm{~nm}$ ). Rats were treated with a single intravenous injection of a suspension of $\mathrm{TiO}_{2}$ NPs in serum (5 mg/kg BW), and the tissue content of $\mathrm{TiO}_{2} \mathrm{NPs}$ was determined 1,14 , and 28 days later. The $\mathrm{TiO}_{2} \mathrm{NP}$ levels were highest in the liver, followed in decreasing order by the levels in the spleen, lung, and kidneys, and the highest organ burdens were on day 1 postexposure. $\mathrm{TiO}_{2}$ NP levels were retained in the liver for 28 days which was the duration of the experiment. There was a slight decrease in $\mathrm{TiO}_{2}$ NP levels from day 1 to days 14 and 28 in the spleen, and a return to control levels by day 14 in the lung and kidneys. In this study, there were no detectable levels of $\mathrm{TiO}_{2} \mathrm{NPs}$ in blood cells, plasma, brain, or lymph nodes at 1,14 , and 28 days post-exposure, suggesting a rapid clearance of the $\mathrm{TiO}_{2}$ NPs from the blood into the lung, spleen, kidneys, and liver. $\mathrm{TiO}_{2} \mathrm{NPs}$ had not been entirely cleared from the liver and spleen within the observation period, indicating that $\mathrm{TiO}_{2}$ NPs can accumulate in these organs after continuous intravenous exposure. It should be noted that these intravenous exposure levels were high, which may have influenced organ distribution by damaging the integrity of the endothelial barrier.

In a two week acute toxicity study [96], mice were intraperitoneally injected with different doses of $\mathrm{TiO}_{2} \mathrm{NPs}$ (0, 324, 648, 972, 1296, 1944 or $2592 \mathrm{mg} / \mathrm{kg} \mathrm{BW})$. Examination of particle distribution demonstrated that at 1,2 , 7 , and 14 days post-exposure accumulation of $\mathrm{TiO}_{2} \mathrm{NPs}$ (80 nm, $100 \mathrm{~nm}$, anatase) was highest in spleen, followed by liver, kidneys and lung in a decreasing order. Accumulation of $\mathrm{TiO}_{2} \mathrm{NPs}$ in the spleen was the highest throughout the experimental period. Some of the particles were excreted from the kidneys (urine). These results indicated that $\mathrm{TiO}_{2}$ NPs could be transported to 
and deposited in other tissues or organs after intraperitoneal injection, although the use of extremely high intraperitoneal injection exposure doses may have affected the results. Liu et al. [97] investigated distribution of $\mathrm{TiO}_{2}$ anatase NPs (5 nm; 5, 10, 50, 100, and $150 \mathrm{mg} / \mathrm{kg}$ $\mathrm{BW}$ ) after intraperitoneal injection in mice daily for 14 days. They found the order of the accumulation of $\mathrm{TiO}_{2}$ NPs in the organs was liver $>$ kidneys $>$ spleen $>$ lung $>$ brain $>$ heart. The content of $\mathrm{TiO}_{2}$ NPs in the liver at the dose of $50 \mathrm{mg} / \mathrm{kg}$ was higher than that of $\mathrm{TiO}_{2}$ FPs at the same dose. A study by Ma et al. [98] found that $\mathrm{TiO}_{2}$ NPs (anatase, $5 \mathrm{~nm} ; 5,10,50,100$, and $150 \mathrm{mg} / \mathrm{kg}$ BW; daily for 14 days) translocated from the site of injection, the abdominal cavity, to the brain causing oxidative stress and brain injury in ICR mice. Again, relevance of such injury is an issue due to the high exposure doses used.

These studies have shown that $\mathrm{TiO}_{2}$ NPs distributed to other organs after intravenous or intraperitoneal administration. Most of the NPs accumulated in the liver. $\mathrm{TiO}_{2}$ NPs were found in the brain after intranasal administration. However, these studies used high doses, which greatly exceed levels likely after anticipated exposures (occupational, medical, consumer use, etc.). Therefore, further investigation is necessary.

\section{Metabolism}

So far we have not found specific literature regarding the metabolism of $\mathrm{TiO}_{2}$ NPs.

\section{Excretion}

Similar to other inorganic NPs, $\mathrm{TiO}_{2}$ NPs in the systemic circulation has two potential pathways for clearance, i.e., kidneys/urine and bile/feces. The International Program on Chemical Safety for $\mathrm{TiO}_{2}$ shows that most ingested $\mathrm{TiO}_{2}$ is excreted with urine [99]. Clearance of particles from the liver via the bile into the feces is well known in pharmaceutics and is also postulated for $\mathrm{TiO}_{2}$ NPs [100]. Furthermore, every NP not absorbed by the gut epithelium will presumably be eliminated from the body via this pathway. Similarly, inhaled $\mathrm{TiO}_{2}$ NPs which are deposited in the airways of the respiratory tract and phagocytized by alveolar macrophages may be transported by mucociliary action to the larynx from where they can be cleared via expiration of sputum or be swallowed entering the GIT. Although NPs deposited in the alveoli can either be translocated to the interstitium, lymph nodes, or pulmonary capillaries, the majority are cleared by macrophage-mediated transport to the distal end of the mucociliary escalator. A study found that alveolar clearance for $\mathrm{TiO}_{2}$ FPs $(5.35,10.7$, and $21.41 \mathrm{mg} / \mathrm{rat}$; Ti IV 100\% rutile; $1 \mu \mathrm{m} ; 7$ and 42 days post-exposure) via macrophage phagocytosis was greater than $\mathrm{TiO}_{2}$ NPs $(0.26,0.52$, and $1.04 \mathrm{mg} / \mathrm{kg}$; P-25, 80/20 anatase/rutile; $21 \mathrm{~nm}$ ) [16]. This was attributed to the higher rate of interstitialization of $\mathrm{TiO}_{2} \mathrm{NPs}$. An in vivo inhalation study reported similar results. They found that clearance of $\mathrm{TiO}_{2} \mathrm{NPs}\left(20 \mathrm{~nm} ; 7.2 \times 10^{6}\right.$ particles $/ \mathrm{ml} ; 1 \mathrm{~h}$ and $24 \mathrm{~h}$ post-exposure) from the lung by lung surface macrophages is relatively low [101]. This was based on data analysis which revealed an uptake of 0.06 to $0.12 \%$ $\mathrm{TiO}_{2} \mathrm{NPs}$ by lung-surface macrophages within $24 \mathrm{~h}$. Ineffective macrophage clearance of inhaled NPs from the peripheral lung would lead to bio-persistence of $\mathrm{TiO}_{2}$ NPs and/or favors their translocation into the lung interstitium and then to the vasculature, potentially enhancing adverse systemic effects [101]. Hydrogen-1 nuclear magnetic resonance spectroscopy (1H-NMR) was used to analyze urine metabolites of rats exposed by intratracheal instillation to low $(0.8 \mathrm{mg} / \mathrm{kg})$, medium $(4 \mathrm{mg} / \mathrm{kg})$ and high $(20 \mathrm{mg} / \mathrm{kg})$ doses of $\mathrm{TiO}_{2}$ NPs [102]. Significant metabolite (acetate, valine, dimethylamine, taurine, hippurate, and 2-oxoglutarate) changes were only observed in the low dose group. These compensatory changes resolve within seven days, and the results of serum biochemical assays also implied no parenchymal damages in the liver or kidney. They concluded that low dose instillation of $\mathrm{TiO}_{2}$ NPs resulted in a transient impact on metabolic function because the scattered NPs can migrate from the lung to liver or kidney. In contrast, $\mathrm{TiO}_{2}$ NPs form agglomerates at higher doses which decreases migration to systemic organs.

In summary, absorption, distribution, metabolism, and excretion of $\mathrm{TiO}_{2}$ NPs may be affected by various factors including routes of exposures and particle size, particle agglomeration and surface coating. The most frequently investigated exposure routes in the toxicokinetics studies of $\mathrm{TiO}_{2}$ NPs were pulmonary, lung inhalation, dermal and oral administrations. $\mathrm{TiO}_{2} \mathrm{NPs}$ can be absorbed into the body through the lung and GIT. Further studies are needed to quantify the magnitude of such transport so that systemic risk can be assessed. There is no sufficient evidence available to indicate that $\mathrm{TiO}_{2}$ NPs have the ability to penetrate through the intact skin into the human body under normal conditions. $\mathrm{TiO}_{2} \mathrm{NPs}$ injected intravenously or intra-peritoneally were found in different organs, such as liver, spleen, kidneys, lung, lymph nodes, and brain. $\mathrm{TiO}_{2}$ NPs may have the potential to penetrate the blood-brain barriers (BBB) and bloodplacenta barriers. However, these studies employed very high doses of $\mathrm{TiO}_{2}$ NPs. Elimination of $\mathrm{TiO}_{2}$ NPs may be through kidneys/urine, and bile/feces. Though a large fraction of absorbed $\mathrm{TiO}_{2}$ NPs could be excreted rapidly, it is possible that not all of these particles will be eliminated from the body. As a result, accumulation of $\mathrm{TiO}_{2}$ NPs in some organs may take place in the human body after continuous exposure. A major site of accumulation seems to be the liver. However, there is a possibility that 
the accumulated $\mathrm{TiO}_{2}$ NPs can be completely cleared from these sites if the study time frame is increased. Therefore, further biokinetic studies are needed. Additionally, translocation of $\mathrm{TiO}_{2} \mathrm{NPs}$, at relevant lower doses, should be conducted to determine if the presence of $\mathrm{TiO}_{2}$ NPs at systemic sites alters their normal biological function and anatomical morphology. For example, pulmonary exposures of NPs did not cause extensive damage to the air/blood barrier, NP translocation was slow, representing less than $1 \%$ of the initial pulmonary burden at 1 week post-exposure [91]. The possible toxicokinetics of $\mathrm{TiO}_{2} \mathrm{NPs}$ and accumulation sites are summarized in Figure 2.

\section{Toxicity of $\mathrm{TiO}_{2} \mathrm{NPs}$}

The toxic effects of test substances are usually measured in terms of acute, sub-acute, sub-chronic or chronic exposure conditions. Studies with a maximum of 2 weeks (14 days) study duration are normally referred to as acute toxicity studies. Sub-acute toxicity studies last for a maximum of 4 weeks (28 days), sub-chronic toxicity studies for a maximum of 13 weeks (90 days) and chronic toxicity studies last longer than 4 months. The toxicity of $\mathrm{TiO}_{2}$ NPs will be discussed in terms of these types of studies.

\section{Acute toxicity}

Acute toxicity information for $\mathrm{TiO}_{2}$ NPs in humans is currently lacking. A value often given in animal toxicity studies is the median lethal dose $\left(\mathrm{LD}_{50}\right) /$ median lethal concentration $\left(\mathrm{LC}_{50}\right)$, which is defined as the dosage/ concentration resulting in the death of $50 \%$ of the experimental animals. However, due to ethical reasons, this method of acute toxicity testing was abolished in 2002 from the Organization for Economic Co-operation and Development (OECD) acute toxicity guideline (TG 401) and is not recommended. However, there are other alternative methods such as fixed dose procedure (TG 420), up and down procedure (TG 423) and dose response method (TG 425) that can be used to determine the $\mathrm{LD}_{50}$. The acute toxicity studies are mentioned in the order; inhalation, intra-tracheal instillation, dermal, oral, intraperitoneal, and in vitro.

In an inhalation study, rats were exposed to aerosols of 0,2 , 10 , or $50 \mathrm{mg} / \mathrm{m}^{3} \mathrm{TiO}_{2} \mathrm{NPs}$ by inhalation for $6 \mathrm{~h} /$ day for 5 days [103]. Necropsies were performed either immediately after the last exposure or after 3 and 16 days post-exposure. Lung inflammation was associated with dose-dependent increases in bronchoalveolar lavage fluid (BALF) total cell and neutrophil counts, total protein content, enzyme activities and levels of a number of cell mediators. No indications of systemic effects were

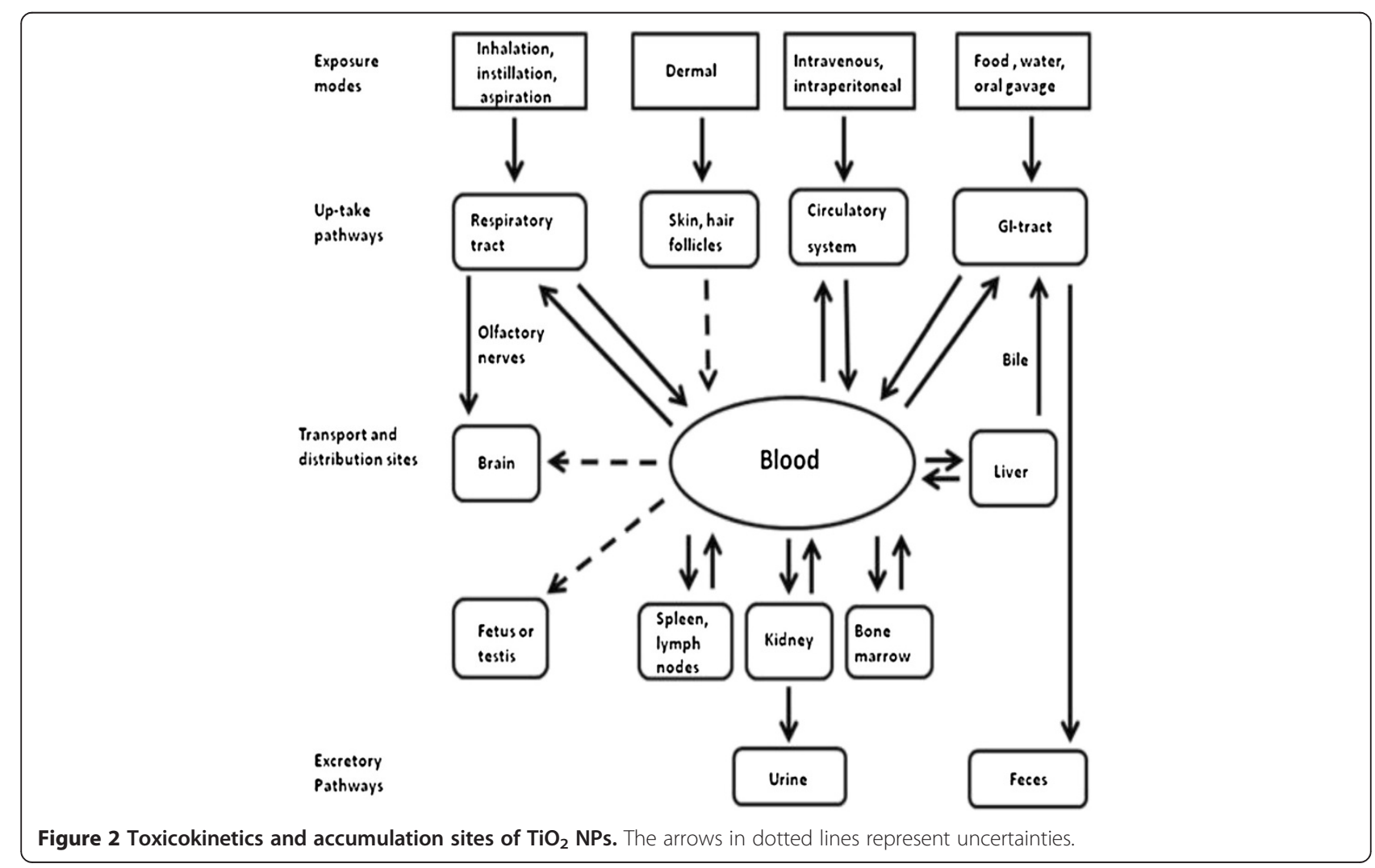


found by measurement of appropriate clinical pathological parameters. An inhalation study on mice [104], exposed to $\mathrm{TiO}_{2}$ NPs $\left(2-5 \mathrm{~nm} ; 8.88 \mathrm{mg} / \mathrm{m}^{3}\right.$; $4 \mathrm{~h} /$ day for 10 days) showed higher counts of total cells and alveolar macrophages in the BALF. However, mice recovered by week 3 post-exposure. These inhalation studies showed that at sufficient lung burdens in both rats and mice $\mathrm{TiO}_{2}$ NPs can cause pulmonary inflammation. Nurkiewicz et al. [105] reported that inhalation of nano- or fine $\mathrm{TiO}_{2}$ ( $21 \mathrm{~nm}$ or $1 \mu \mathrm{m} ; 1.5$ or $20 \mathrm{mg} / \mathrm{m}^{3} ; 24 \mathrm{~h}$ post-exposure) caused microvascular dysfunction in arterioles of the shoulder muscle, i.e., a failure to respond to dilators. On a mass basis, nano $\mathrm{TiO}_{2}$ was 6-7 times more potent than fine $\mathrm{TiO}_{2}$. However, the difference in potency was not present when dose was normalized to particle surface area delivered to the lungs. A recent study by the same research group found that the peripheral vascular effects associated with particulate matter (PM) exposure $\left(\mathrm{TiO}_{2} \mathrm{FP} 710 \mathrm{~nm}\right.$ and NP $100 \mathrm{~nm}$; inhalation $1.5-16 \mathrm{mg} / \mathrm{m}^{3}$ for $4-12 \mathrm{~h}$ ) are due to the activation of inflammatory and/or neurogenic mechanisms [106]. In addition, an increase in basal tone and a decreased responsiveness of coronary arterioles to dilators was noted 1 day after inhalation of nano $\mathrm{TiO}_{2}$ (21 nm; P-25:80/20 anatase/rutile; $6 \mathrm{mg} / \mathrm{m}^{3}$; at $24 \mathrm{~h}$ post-exposure) in another study [107]. It should be noted that microvascular dysfunction was reported at low lung burdens which did not significantly alter BALF measures of lung inflammation or damage. These findings are of interest because there are known associations between PM and cardiovascular diseases. PM exposure can result in significant changes in many cardiovascular indices, such as heart rate, heart rate variability, blood pressure, and blood coagulability [108].

Liu et al. [109] treated rats by intra-tracheal instillation with a single dose of $0.5,5$, or $50 \mathrm{mg} / \mathrm{kg}$ BW of $\mathrm{TiO}_{2}$ NPs $(5,21$, or $50 \mathrm{~nm}$, respectively). Rats were sacrificed one week post-exposure. Histopathological examinations of lung tissue indicated that exposure to $\mathrm{TiO}_{2}$ NPs induced dose-dependent inflammatory lesions in rats. In addition, on an equal mass basis, pulmonary toxicity induced by $5 \mathrm{~nm} \mathrm{TiO}_{2}$ NPs was more severe than those induced by 21 and $50 \mathrm{~nm} \mathrm{TiO}_{2}$ particles. The time course of pulmonary responses was reported in a study by Kobayashi et al. [110] at 1 and 7 days after rats were intra-tracheal instilled (19 and $28 \mathrm{~nm} ; 5 \mathrm{mg} / \mathrm{ml}$ ) with $\mathrm{TiO}_{2}$ NPs. The $\mathrm{TiO}_{2}$ NPs showed greater pulmonary inflammatory effect $24 \mathrm{~h}$ after exposure then 1 week after exposure. In these studies, the inflammatory effects of $\mathrm{TiO}_{2}$ NPs were locally distributed, dose dependent and recovery was probable. The effects of $\mathrm{TiO}_{2} \mathrm{NPs}$ on the immune function were investigated by Liu et al. [111]. They evaluated immune function of rat alveolar macrophages (AM) exposed to $\mathrm{TiO}_{2}$ NPs (intratracheal instillation) and reported damage to the cell structure and AM dysfunction, leading to a reduction in both non-specific and specific immune responses in individuals exposed to $\mathrm{TiO}_{2}$ NPs (5 and $200 \mathrm{~nm}$; 0.5, 5, or 50 $\mathrm{mg} / \mathrm{kg}$ ). The phagocytic ability of the macrophages increased when exposed to a low dose of $\mathrm{TiO}_{2}$ NPs and decreased when exposed to a high dose of $\mathrm{TiO}_{2}$ NPs. Exposure to $\mathrm{TiO}_{2}$ NPs also decreased the chemotactic ability of the macrophages and the expression of Fc receptors and MHC-class II on the cell surface. The mechanism responsible for these changes was mediated via altering nitric oxide (NO) and tumor necrosis factor- $\alpha$ (TNF- $\alpha$ ) expression by the AM. The amount of NO and TNF- $\alpha$ secreted by macrophages was gradually increased when the dosage of $\mathrm{TiO}_{2}$ NPs increased. $\mathrm{TiO}_{2}$ NPs elicited greater NO and TNF- $\alpha$ production than FPs. This research group attributed the potency of $\mathrm{TiO}_{2}$ NPs to surface area and crystal structure [112]. The involvement of TNF- $\alpha$ in late airway hyper responsiveness (AHR) has recently been investigated. In a study, low pulmonary doses of $\mathrm{TiO}_{2}$ NPs were shown to aggravate pulmonary inflammation and AHR in a mouse model of toluene diisocyanate (TDI)-induced asthma [113]. To investigate the modulation of an asthmatic response by $\mathrm{TiO}_{2}$ NPs (99.9\% anatase; $15 \mathrm{~nm}$ ) in a murine model of diisocyanate-induced asthma, the investigators in this study treated mice on days 1 and 8 with $0.3 \%$ TDI or the vehicle acetone-olive oil (AOO) on the dorsum of both ears $(20 \mu \mathrm{l})$. On day 14 , the mice were oropharyngeally dosed with $40 \mu \mathrm{l}$ of $\mathrm{TiO}_{2} \mathrm{NP}$ suspension $(0.8 \mathrm{mg} / \mathrm{kg} \mathrm{BW})$. One day later (day 15$)$, the mice received an oropharyngeal challenge with $0.01 \%$ TDI $(20 \mu \mathrm{l})$. On day 16, airway hyper-reactivity (AHR), BAL cell and cytokine levels, lung histology, and total serum immunoglobulin $\mathrm{E}$ were assessed. $\mathrm{TiO}_{2} \mathrm{NP}$ exposure in sensitized mice led to a 2 fold increase in AHR, and a 3 fold increase in BAL total cell count, mainly comprising neutrophils and macrophages. Histological analysis revealed increased edema, epithelial damage and inflammation. These studies suggest $\mathrm{TiO}_{2} \mathrm{NPs}$ can act as an airway irritant. Thus, if the compromised hosts are exposed to $\mathrm{TiO}_{2}$ NPs it may aggravate their condition.

Using acute dermal irritation studies in rabbits and the local lymph node assay in mice (CBA/JHsd mice), Warheit et al. [114] concluded that $\mathrm{TiO}_{2} \mathrm{NPs}(129.4 \mathrm{~nm}$ in $\mathrm{H}_{2} \mathrm{O} ; 80 / 20$ anatase/rutile; $0 \%, 5 \%, 25 \%, 50 \%$, or $100 \%$ $\mathrm{TiO}_{2}$ NPs, 3 consecutive days) were not a skin irritant or dermal sensitizer. Another study reported that acute dermal, eye and vaginal mucous membrane irritation tests revealed no significant irritation in $\mathrm{TiO}_{2} \mathrm{NP}$ (size not given; 1000, 2,150, 4,640, and 10,000 mg/kg BW) treated mice at 1,24 , or $48 \mathrm{~h}$ post-exposure [115]. In a 14 days toxicity study, $\mathrm{TiO}_{2}$ NPs (20 nm; 14, 28, 42, 
and $56 \mathrm{mg} / \mathrm{kg}$ ) applied topically on Wistar rat skin induced short term toxicity at the biochemical level [116]. Depletion in the levels of catalase and glutathione S-transferase (GST) activity were observed. In addition, there was an increase in the activity of lactate dehydrogenase $(\mathrm{LDH})$ and lipid peroxidation (LPO). The levels of serum glutamic pyruvic transaminase (SGPT), serum glutamic oxaloacetic transaminase (SGOT), blood urea nitrogen (BUN), and creatinine were also increased. However, the histopathological studies did not show any observable effects at the tissue level. They concluded that short term dermal exposure to $\mathrm{TiO}_{2} \mathrm{NPs}(42 \mathrm{mg} / \mathrm{kg} \mathrm{BW})$ can cause hepatic, as well as renal, toxicity in rats. The two studies cited here, in regards to dermal exposure, agree with a study mentioned earlier in the section on toxicokinetics. However, the findings of the latter study suggest that the hair follicles may be a way for $\mathrm{TiO}_{2}$ NPs to penetrate into live skin. It should be noted that the doses used in these studies are high and do not mimic likely human exposures.

Warheit et al. [114] reported in acute oral toxicity studies that $\mathrm{TiO}_{2}$ NPs $\left(129.4 \mathrm{~nm}\right.$ in $\mathrm{H}_{2} \mathrm{O} ; 175,550,1750$ or $5000 \mathrm{mg} / \mathrm{kg} ; 80 / 20$ anatase/rutile; $48 \mathrm{~h}$ intervals for 14 days) were very low in toxicity and produced shortterm and reversible ocular conjunctiva redness in rabbits. In another study, the acute toxicity in mice was investigated after a single oral administration of $\mathrm{TiO}_{2}$ particles (25, 80, and $155 \mathrm{~nm} ; 5 \mathrm{~g} / \mathrm{kg} \mathrm{BW)} \mathrm{[59].} \mathrm{Over}$ two weeks post-exposure, $\mathrm{TiO}_{2}$ particles showed no obvious acute toxicity. However, the female mice showed high hepatic coefficients in the 25 and $80 \mathrm{~nm}$ groups. The changes of serum biochemical parameters (alanine aminotransferase (ALT), aspartate aminotransferase (AST), LDH, and BUN), and pathology of the liver and kidney indicated that hepatic renal injury was induced after exposure. Even though there were significant changes of serum LDH in $\mathrm{TiO}_{2} \mathrm{NP}$ (25 and $80 \mathrm{~nm}$ ) treated animals, indicating the presence of myocardial damage, the pathology results for the heart, lung, testicles (ovary), or spleen showed no abnormal changes. These oral exposure studies showed biochemical changes, but systemic toxicity was not demonstrated.

Intraperitoneal studies may be done to address the effects of possible $\mathrm{TiO}_{2} \mathrm{NP}$ use in nanomedicine. At the higher doses of an intraperitoneal exposure study done on mice, $\mathrm{TiO}_{2}$ NPs (anatase, $5 \mathrm{~nm} ; 5,10,50,100$, and $150 \mathrm{mg} / \mathrm{kg} \mathrm{BW}$; everyday for 14 days) caused serious damage to the liver, kidneys, and myocardium and disturbed the balance of blood sugar and lipid [97]. Furthermore, with increasing doses of $\mathrm{TiO}_{2}$ NPs, indicators of liver function, such as ALT, leucine acid peptide, pseudocholinesterase, total protein, and albumin levels, were enhanced significantly; the indicators of kidney function, such as uric acid and BUN, were decreased; and the activities of AST, creatine kinase (CK), LDH, and alpha-hydroxybutyrate dehydrogenase, indicators of the myocardium function, were increased. The contents of triglycerides, glucose, and high-density lipoprotein cholesterol were significantly elevated. The authors concluded that the accumulation of $\mathrm{TiO}_{2} \mathrm{NPs}$ in the organs might be closely related to the differences in the coefficients of organs and the inflammatory responses of mice. In addition, they reported that the $\mathrm{LD}_{50}$ value of $\mathrm{TiO}_{2}$ NPs through intraperitoneal injection in mice was 150 $\mathrm{mg} / \mathrm{kg}$ BW. Mice intraperitoneally injected with $\mathrm{TiO}_{2}$ NP (50 nm; 0, 324, 648, 972, 1296, 1944 or $2592 \mathrm{mg} / \mathrm{kg}$; 24 h, 48 h, 7 days, and 14 days) showed signs of acute toxicity, such as passive behavior, loss of appetite, tremor, and lethargy. Slightly elevated levels of ALT and AST were observed. Histopathological examinations showed that some $\mathrm{TiO}_{2}$ NPs entered the spleen and caused lesions. Thrombosis was found in the pulmonary vascular system. In addition, hepatocellular necrosis and apoptosis, hepatic fibrosis, renal glomerular swelling and interstitial pneumonia associated with alveolar septal thickening were also observed in the high dose group. Ma et al. [117] stated that inflammatory responses and liver injury may be involved in $\mathrm{TiO}_{2} \mathrm{NP}(5 \mathrm{~nm} ; 5,10,50$, 100 , and $150 \mathrm{mg} / \mathrm{kg} \mathrm{BW}$; everyday for 14 days) induced liver toxicity. The real-time quantitative PCR (RT-PCR) and enzyme-linked immunosorbent assay (ELISA) analyses showed that $\mathrm{TiO}_{2}$ NPs can significantly alter the mRNA and protein expression of several inflammatory pathways, including nuclear factor kappa-light-chainenhancer of activated B cells (NF- $\mathrm{k}$ ), macrophage migration inhibitory factor (MMIF), TNF- $\alpha$, interleukin (IL)-6 (IL-6), IL-1 $\beta$, cross-reaction protein, IL-4, and IL-10. In addition to this, we have already mentioned some studies $[19,25,118]$ that have also reported the inflammatory effects of $\mathrm{TiO}_{2} \mathrm{NPs}$. $\mathrm{TiO}_{2}$ NPs also induce some neurons to turn into filamentous shapes and others into inflammatory cells after translocating from the abdominal cavity [98]. Oxidative stress and injury of the brain triggered a cascade of reactions, such as LPO, decreases of the total anti-oxidation capacity and activities of antioxidative enzymes, the excessive release of $\mathrm{NO}$, the reduction of glutamic acid, and the down-regulated level of acetylcholinesterase activity. The acute toxicity of intraperitoneally injected $\mathrm{TiO}_{2}$ NPs is systemic, it involves pathological and biochemical effects on the liver, kidney, heart and brain.

Since in vitro studies can be used as predictive indicators of acute toxicity, some are mentioned here. The influence $\mathrm{TiO}_{2}$ NPs on erythrocytes was systematically investigated by Li et al. [119]. Their results indicate that erythrocytes treated with $\mathrm{TiO}_{2}$ NPs underwent abnormal sedimentation, hemagglutination and dose dependent hemolysis, which totally differed from cells treated with 
$\mathrm{TiO}_{2}$ FPs. Another study reported that hemolysis (washed human erythrocytes, $37^{\circ} \mathrm{C}$ incubation for $1 \mathrm{~h}$ ) caused by $\mathrm{TiO}_{2}$ FPs was 73 times greater than $\mathrm{TiO}_{2}$ NPs [120]. However, the hemolysis was abolished by plasma, indicating that in in vivo conditions the presence of plasma may prevent hemolysis. A study on mouse macrophages (Ana-1 and MH-S cells) found that $\mathrm{TiO}_{2} \mathrm{NPs}$ $(5,10,25$, and $100 \mathrm{~nm}$; anatase) caused low toxicity to $\mathrm{MH}-\mathrm{S}$ cells [121]. Another study found $\mathrm{TiO}_{2}$ NPs (25 and $80 \mathrm{~nm} ; 0,10,20,40$, and $80 \mathrm{mg} / \mathrm{l} ; 24 \mathrm{~h}$ ) inhibited gap junction intracellular communication between lung fibroblasts [122]. A number of in vitro studies also show toxic effects of $\mathrm{TiO}_{2}$ NPs on cells of the circulatory system.

In summary, the acute toxicity of $\mathrm{TiO}_{2}$ NPs have been frequently studied in rat and mouse models following multiple exposure routes of administration. The number of studies targeting the respiratory system outweighs the other exposure routes. Studies exposing the pulmonary system to $\mathrm{TiO}_{2}$ NPs produced both local and systemic symptoms and aggravate pre-existing symptoms. $\mathrm{TiO}_{2}$ NPs administered through the lung are more inflammatory than FPs of similar chemistry at equal mass concentrations. However, on an equal particle surface area basis, pulmonary inflammation to $\mathrm{TiO}_{2}$ NPs was similar to that of $\mathrm{TiO}_{2}$ FPs. The results from the other exposure routes cannot be ignored. For example, research evidence demonstrates that $\mathrm{TiO}_{2}$ NPs can be absorbed through the lung or GIT into the systemic circulation and then distributed in different organs such as the liver, kidneys, spleen, or even the brain. Distribution and accumulation of $\mathrm{TiO}_{2}$ NPs in the organs could induce organ injuries and inflammatory responses. However, most of the doses employed are too high to be realistic in occupational settings. In vitro studies also show effects of $\mathrm{TiO}_{2}$ NPs on the blood circulation system.

\section{Sub- acute toxicity}

Silicon dioxide $\left(\mathrm{SiO}_{2}\right)$-coated rutile $\mathrm{TiO}_{2}$ NPs $(40 \mathrm{~nm} ; 10$ $\mathrm{mg} / \mathrm{m}^{3} ; 2 \mathrm{~h}$ on 4 consecutive days, or $2 \mathrm{~h}$ on 4 consecutive days, 4 weeks) caused pulmonary neutrophilia, increased expression of TNF- $\alpha$ and neutrophil attracting chemokine (CXCL 1) in lung tissues [123]. However, they attributed the effects to the surface coating with $\mathrm{SiO}_{2}$. Others observed that $\mathrm{TiO}_{2}$ NPs caused minimal inflammatory changes in the lungs, leucopenia, and a decrease in $\beta$-glucuronidase after inhalation [92].

In another study [124], rats were intra-tracheally instilled with $\mathrm{TiO}_{2}$ NPs (1 or $10 \mathrm{mg} / \mathrm{kg} \mathrm{BW).} \mathrm{At} 10 \mathrm{mg} / \mathrm{kg}$ BW, LDH activity $(1,7,14$, and 28 days), malodialdehyde (MDA) (1, 7, and 14 days), total protein (1 and 7 days), as well as, the number of leukocytes ( 1 and 7 days) were all increased significantly when compared with the controls. Histopathological examination revealed a marked increase of pulmonary inflammation in the lungs in $10 \mathrm{mg} / \mathrm{kg} \mathrm{BW}$ treated rats. While investigating doseresponse relationships for intra-tracheal instillation of $\mathrm{TiO}_{2}$ NPs $(20 \mathrm{~nm})$ and FPs $(250 \mathrm{~nm})$, Oberdorster et al. [125] observed a significant pulmonary inflammatory response to $\mathrm{TiO}_{2}$ NPs in rats and mice, which included an increase of total protein in BALF, LDH activity, and acid-glucosidase. They concluded that the greater toxicity of the $\mathrm{TiO}_{2}$ NPs correlated well with their greater surface area per mass. Li et al. [79] investigated the effects of $\mathrm{TiO}_{2} \mathrm{NPs}(3 \mathrm{~nm})$ in mice after intra-tracheal instillation at a total dose of $13.2 \mathrm{mg} / \mathrm{kg} \mathrm{BW}$ (once a week for 4 weeks). At 28 days after instillation, they found that instilled $\mathrm{TiO}_{2}$ NPs could induce lung damage, and change the permeability of the alveolar-capillary barrier. $\mathrm{TiO}_{2}$ NPs were able to access the blood circulation and reach extra-pulmonary tissues, such as the liver and kidneys, leading to different levels of tissue injury. In addition, $\mathrm{TiO}_{2}$ NPs might pass through the BBB and induce the injury through an oxidative stress response. At other sites, $\mathrm{TiO}_{2}$ NPs (1.0, 0.5, and $0.1 \mathrm{mg} / \mathrm{ml}$; twice/ week for 6 weeks) caused dyslipidemia and accelerated the development of atherosclerosis and plaque rupture in intra-tracheally instilled ApoE-/-mice [126]. In this study, viscera index, blood total cholesterol (TC), triglyceride (TG), high density lipoprotein cholesterol (HDL-C), low density lipoprotein cholesterin (LDL-C), and organic lipid ratio were assessed as biomarkers. Artery and aortic root issues were assessed by histopathology. Another study investigated whether photocatalytic $\mathrm{TiO}_{2}$ NPs (28 nm; rutile; 2, 10, 50, or $250 \mu \mathrm{g}$ ) exhibited an adjuvant effect, when administered through intraperitoneal injection in combination with ovalbumin (OVA) in mice [127]. The mice in this study were treated with OVA, OVA $+\mathrm{TiO}_{2} \mathrm{NPs}$ or OVA $+\mathrm{AlOH}_{3}$ and challenged with aerosols of OVA. The $\mathrm{TiO}_{2}$ NPs promoted a Th2 dominant immune response with high levels of OVA-specific IgE and IgG1 in the serum, and influx of eosinophils, neutrophils and lymphocytes in BALF. Significantly higher levels of OVA-specific IgE were induced by $\mathrm{TiO}_{2}$ NPs than the standard adjuvant, $\mathrm{AlOH}_{3}$. However, the two substances were comparable regarding the level of eosinophilic inflammation and interleukins present in BALF.

The oral toxicological effects of $\mathrm{TiO}_{2}$ NPs (dosed at $0.16,0.4$, and $1 \mathrm{~g} / \mathrm{kg}$ ) were investigated using conventional approaches and metabolomic analysis in Wistar rats [128]. The urine and serum were analyzed by $1 \mathrm{H}$ NMR using principal components and partial least squares discriminant analyses. The metabolic signature of urinalysis in $\mathrm{TiO}_{2}$ NPs-treated rats showed increases in the levels of taurine, citrate, hippurate, histidine, trimethylamine-N-oxide (TMAO), citrulline, alphaketoglutarate, phenylacetylglycine (PAG) and acetate. 
Decreases in the levels of lactate, betaine, methionine, threonine, pyruvate, 3-D-hydroxybutyrate (3-D-HB), choline and leucine were also observed. The metabolomics analysis of serum showed increases in TMAO, choline, creatine, phosphocholine and 3-D-HB as well as decreases in glutamine, pyruvate, glutamate, acetoacetate, glutathione and methionine after $\mathrm{TiO}_{2}$ NPs treatment. AST, CK and $\mathrm{LDH}$ were elevated and mitochondrial swelling in heart tissue was observed in $\mathrm{TiO}_{2}$ NPs-treated rats. They concluded that their findings indicated that disturbances in energy and amino acid metabolism, and the gut microflora environment may be attributable to slight injury to the liver and heart caused by $\mathrm{TiO}_{2}$ NPs. They proposed that the NMR-based metabolomic approach may be a reliable and sensitive method to study the biochemical effects of nanomaterials. What one can crudely deduce from these findings is that, in terms of occupational exposures, those with underlying health issues such as asthma and heart disease may be at risk of $\mathrm{TiO}_{2}$ NPs toxicity. However, since the studies were conducted in animals, there is a need for epidemiological studies in the workplace, to quantify the risks of $\mathrm{TiO}_{2}$ NPs in the workplace. This is further discussed in part IX, the epidemiological studies section.

\section{Sub-chronic toxicity}

A subchronic inhalation study comparing pulmonary responses to $\mathrm{TiO}_{2}$ NPs in several species was performed [129]. Female rats, mice, and hamsters were exposed to aerosol concentrations of $0.5,2.0$, or $10 \mathrm{mg} / \mathrm{m}^{3} \mathrm{TiO}_{2}$ NPs (P-25; $21 \mathrm{~nm} ; 6 \mathrm{~h} /$ day, 5 days/week, for 13 weeks). At each time point, $\mathrm{TiO}_{2}$ NPs burdens in the lung and lymph nodes and selected lung responses were examined. Retained lung burdens increased in a dosedependent manner in all three species and were at a maximum at the end of exposures. There were significant species differences in the pulmonary responses to inhaled $\mathrm{TiO}_{2}$ NPs. Under conditions where the lung $\mathrm{TiO}_{2}$ NPs burdens were equivalent, rats developed a more severe inflammatory response than mice and, subsequently, developed progressive epithelial and fibroproliferative changes. Clearance of particles from the lung was markedly impaired in mice and rats exposed to $10 \mathrm{mg} / \mathrm{m}^{3} \mathrm{TiO}_{2} \mathrm{NPs}$, whereas clearance in hamsters did not appear to be affected at any of the administered doses.

Warheit et al. [130] intra-tracheally instilled $\mathrm{TiO}_{2} \mathrm{NPs}$ (25 and $100 \mathrm{~nm} ; 1$ or $5 \mathrm{mg} / \mathrm{kg} \mathrm{BW;} 24 \mathrm{~h}, 1$ week and 3 months) into rats to compare several types of $\mathrm{TiO}_{2}$ FPs and NPs with different sizes, surface areas, and crystal structures. In the comparison among these particles, even though the difference in surface areas was as large as 30 fold, the observed lung inflammatory responses were almost the same for the two particle sizes. They, therefore, concluded that toxicities of $\mathrm{TiO}_{2}$ particles through lung instillation are not dependent upon particle size and surface area. In addition, the same research group suggested that the toxicity was dependent on particle surface properties instead of surface areas. Roursgaard et al. [131] intratracheally instilled mice with single fixed doses of 5, 50, and $500 \mu \mathrm{g}$ of $\mathrm{TiO}_{2}$ FPs and NPs (rutile). They found, in the acute phase, both FPs and NPs induced elevation of IL-6 and total protein in BALF at the highest doses. Similar effects were observed in acute $(24 \mathrm{~h})$ and sub-chronic (3 months) airway inflammation for two different sizes of $\mathrm{TiO}_{2}$ particles. These results suggest that $\mathrm{TiO}_{2}$ NPs may not be more cytotoxic or cause more inflammation to the lungs compared to FPs of similar composition. However, the results in both the Warheit et al. and Roursgaard et al. studies may be questioned due to poor dispersion of $\mathrm{TiO}_{2}$ NPs as suggested by Sager et al. [16]. Indeed, structural sizes of the different particles as delivered to the rats did not sifnificantly differ.

Wang et al. [132] investigated the influence of intranasally instilled $\mathrm{TiO}_{2}$ NPs on monoaminergic neurotransmitters at different times post-exposure (25, 80, and 155 $\mathrm{nm} ; 50 \mathrm{mg} / \mathrm{kg} ; 2,10,20$, and 30 days) in CD female mice. They used ICP-MS to analyze the $\mathrm{TiO}_{2}$ NP contents in murine brain. The monoaminergic neurotransmitters such as NE, DA, 5-HT, 5-HIAA, DOPAC, and HVA, were determined by reversed-phase high performance liquid chromatography (RP-HPLC) with an electrochemical detector. $\mathrm{TiO}_{2} \mathrm{NPs}$ in murine brain increased after 10 days for the $25 \mathrm{~nm}$ group $((1059.3+/-293.5)$ $\mathrm{ng} / \mathrm{g})$. It declined slowly at 20 days post-exposure $((654.7+/-269.2) \mathrm{ng} / \mathrm{g})$. At 30 days post-exposure, the $\mathrm{TiO}_{2}$ NPs content remained the same as at 20 days. Due to the accumulation of $\mathrm{TiO}_{2}$ NPs in the brain, the levels of NE and 5-HT increased significantly after exposure to 80 and $155 \mathrm{~nm} \mathrm{TiO}_{2}$ NPs, while decreases in the levels of DA, DOPAC, HVA and 5-HIAA were observed. The inhaled $\mathrm{TiO}_{2}$ NPs could be translocated to and deposited in murine brain after absorption through the nasal mucosa, and could influence the release and metabolism of monoaminergic neurotransmitters in brain.

$\mathrm{Wu}$ et al. [133] investigated the penetration and potential toxicity of $\mathrm{TiO}_{2}$ NPs after in vitro (porcine ears) and in vivo animal (domestic pig ears, BALB/c hairless mice) dermal exposure. They concluded that $\mathrm{TiO}_{2} \mathrm{NPs}$ (various sizes) cannot penetrate through the SC $24 \mathrm{~h}$ after exposure to isolated porcine skin. However, after being topically applied on pig ear in vivo for 30 days, $\mathrm{TiO}_{2} \mathrm{NPs}$ (4 and $60 \mathrm{~nm} ; 24 \mathrm{mg}$ of $5 \% \mathrm{TiO}_{2}$ on an area of $3 \mathrm{~cm}^{2}$ ) could penetrate through the horny layer, and be located in the deep layer of the epidermis. Moreover, after 60 days dermal $\left(400 \mu \mathrm{g} / \mathrm{cm}^{2}\right)$ exposure in hairless 
mice, $\mathrm{TiO}_{2}$ NPs not only penetrated the skin, but also reached different tissues and induced diverse pathological lesions in several major organs. In addition, they found $\mathrm{TiO}_{2}$ NPs (21 nm, P-25) in the mouse brain without inducing any pathological changes.

$\mathrm{Hu}$ et al. [134] intragastrically instilled ICR mice with $\mathrm{TiO}_{2}$ NPs (5 nm anatase; 0, 5, 10, and $50 \mathrm{mg} / \mathrm{kg} \mathrm{BW;}$ every day for 60 days). Their aim was to determine whether $\mathrm{TiO}_{2}$ NPs exposure results in persistent alterations in nervous system function. The Y-maze test showed that $\mathrm{TiO}_{2}$ NPs exposure could significantly impair the spatial recognition memory. $\mathrm{TiO}_{2}$ NPs also caused disturbances of the homeostasis of trace elements, enzymes and neurotransmitter systems in the mouse brain. They also found that there were significant alterations in the contents of $\mathrm{Ca}, \mathrm{Mg}, \mathrm{Na}, \mathrm{K}, \mathrm{Fe}$, and $\mathrm{Zn}$ in the brain. $\mathrm{TiO}_{2} \mathrm{NPs}$ also significantly inhibited the activities of $\mathrm{Na}^{+} / \mathrm{K}^{+}$-ATPase, $\mathrm{Ca}_{2}^{+}$-ATPase, $\mathrm{Ca}_{2}^{+} / \mathrm{Mg}_{2}^{+}$ATPase, acetylcholine esterase, and nitric oxide synthase (NOS). The contents of some monoamines neurotransmitters, such as NE, DOPAC, 5-HT and its metabolite 5-HIAA, were significantly decreased, while acetylcholine, glutamate, and NO were significantly increased.

\section{Chronic toxicity (excluding carcinogenicity)}

In work environments, the potential chronic toxicity of $\mathrm{TiO}_{2}$ NPs is likely to be of more concern than acute effects. Early studies suggest that $\mathrm{TiO}_{2}$ is not highly toxic.

Chronic lung inhalation studies $[9,135]$ that exposed pigs or rats, respectively, to $\mathrm{TiO}_{2}$ FPs have reported findings of pulmonary pathology such as increased incidences of pneumonia, squamous metaplasia [135], sustained pulmonary responses [136], enhanced proliferation of pulmonary cells, defects in macrophage function [137], alveolar epithelial metaplasia, progressive fibroproliferative lesions [138] and accumulation of macrophages in interalveolar septa [9]. Some studies on $\mathrm{TiO}_{2}$ NPs show similar effects. Oberdorster et al. [15] investigated the correlation between particle size, in vivo particle persistence, and lung injury after a 12 week inhalation $\left(23.5 \pm 2.9 \mathrm{mg} / \mathrm{m}^{3}\right)$ experiment in rats (Fischer 344) exposed to $\mathrm{TiO}_{2}$ particles (20 and $250 \mathrm{~nm}$ ). They reported inflammation and lung injury and concluded that the greater pulmonary effects of NPs, compared to FPs, can be explained by their larger specific surface area, the greater interstitial access, and their altered biopersistence, resulting in increased retention of NPs.

Exposure to $\mathrm{TiO}_{2}$ NPs $(5-6 \mathrm{~nm})$ resulted in chronic spleen injury, in a 90 day study done on ICR mice (intragastric administration; 2.5, 5, and $10 \mathrm{mg} / \mathrm{kg}$; everyday) [139]. Blood cells, platelets, hemoglobin, immunoglobulin and lymphocyte subsets (such as CD3, CD4, CD8, B cell, and natural killer cell) of mice were significantly decreased. There was also a significant increase in the levels of NF- $\kappa$ B, TNF- $\alpha$, MMIF, IL-2, IL-4, IL-6, IL-8, IL-10, IL-18, IL-1 $\beta$, cross-reaction protein, transforming growth factor- $\beta$ (TGF- $\beta$ ), interferon- $\gamma$, Bax, and CYP1A1 expression, and decreases in the levels of $\mathrm{Bcl}-2$ and heat shock protein 70 (Hsp70) expression. Long-term exposure to low dose $\mathrm{TiO}_{2}$ NPs may cause spleen injury, resulting from alteration of inflammatory and apoptotic cytokines expression and reduction of immune capacity.

In conclusion, $\mathrm{TiO}_{2}$ NPs exhibit moderate toxicity, inducing pulmonary inflammatory response and enhanced proliferation of pulmonary cells at relatively high doses. $\mathrm{TiO}_{2}$ NPs are found to induce greater pulmonary inflammatory effects compared to $\mathrm{TiO}_{2}$ FPs. The modulatory effects of $\mathrm{TiO}_{2}$ NPs in asthmatic responses need to be confirmed. As evident in the acute toxicity studies, the chronic toxicity studies also focus on the respiratory system. However, with the increase in consumer use of sunscreens that contain $\mathrm{TiO}_{2}$ NPs, more effort should be put into carrying out chronic exposure studies for topically applied consumer goods.

In all the different types of toxicity study conditions, pulmonary toxicity seems to be a common finding. The number of studies on pulmonary toxicity also outweighs studies of other exposure routes, emphasizing its importance especially in reference to environmental and occupational exposures. Most of these studies also show that the endpoints of oxidative stress and inflammation seem to be most affected. This mechanistic information can be helpful in increasing the specificity and sensitivity of future in vitro and in vivo studies.

\section{Genotoxicity}

The genotoxicity of $\mathrm{TiO}_{2}$ NPs remains controversial [140]. Early studies suggest that $\mathrm{TiO}_{2}$ is not genotoxic in standard assays [141]. In recent years, in vivo and in vitro studies have examined the genotoxicity of $\mathrm{TiO}_{2}$ NPs. Test systems used frequently in in vivo studies of genotoxicity of $\mathrm{TiO}_{2}$ NPs include rat or mouse bone marrow cells. End points used in the in vitro studies include micronucleus ( $\mathrm{MN})$ test, Ames test, mammalian cell gene mutation, DNA breaks, chromosomal alterations, and cell transformation. These genotoxicity endpoints provide useful data for hazard identification of $\mathrm{TiO}_{2}$ NPs.

\section{In vivo studies}

A few in vivo studies have been carried out to investigate the genotoxicity of $\mathrm{TiO}_{2}$ NPs. A study by Yazdi et al. [142] found that inhalation of $\mathrm{TiO}_{2}$ NPs provoked lung inflammation which was strongly suppressed in IL-1Rand IL- $1 \alpha$ - deficient mice. They concluded that the inflammation caused by $\mathrm{TiO}_{2}$ NPs in vivo was driven by IL- $1 \alpha$. The signaling of IL-1R by $\mathrm{TiO}_{2}$ NPs is similar to 
that of asbestos. $\mathrm{TiO}_{2}$ NPs $\left(6 \mathrm{mg} / \mathrm{m}^{3} ; 4 \mathrm{~h}\right)$ also increased the phosphorylation of p38 and troponin 1 in cardiac muscle of rats exposed through inhalation, at 1 day post exposure [143]. These inhalation studies show that $\mathrm{TiO}_{2}$ NPs can affect the expression of certain genes in both the heart and lung.

An intratracheal instillation study showed that hypoxanthine phosphoribosyltransferase (HPRT) mutation frequency was increased in alveolar type II cells from rats exposed to $\mathrm{TiO}_{2}$ NPs (anatase; $18 \mathrm{~nm} ; 100 \mathrm{mg} / \mathrm{kg}$; 15 months) [144]. While in a study by Trouiller et al. [32], $\mathrm{TiO}_{2}$ NPs were genotoxic, clastogenic and caused moderate inflammation in vivo in mice exposed through drinking water $(21 \mathrm{~nm}, \mathrm{P}-25) . \mathrm{TiO}_{2} \mathrm{NPs}$ at $500 \mathrm{mg} / \mathrm{kg}$ BW induced both DNA single and double-strand breaks and chromosomal damage. $\mathrm{TiO}_{2}$ NPs induced 8-hydroxy2 -deoxyguanosine, $\gamma$-H2AX foci, micronuclei, and DNA deletions. The formation of $\gamma-\mathrm{H} 2 \mathrm{AX}$ foci is indicative of DNA double-strand breaks. They suggested that $\mathrm{TiO}_{2}$ NPs-induced genotoxicity in vivo in mice is possibly caused by a secondary genotoxic mechanism associated with inflammation and/or oxidative stress. RT-PCR and ELISA analysis showed that intra-gastrically administered $\mathrm{TiO}_{2}$ NPs (anatase; $5 \mathrm{~nm} ; 5,10$, and 50 $\mathrm{mg} / \mathrm{kg}$; everyday for 60 days) significantly increased mRNA and protein expression of Toll-like receptor-2 (TLR2), TLR-4, IкB kinases (IKK- $\alpha$, IKK- $\beta$ ), NF-кB, NF-кBP52, NF-кBP65, TNF- $\alpha$, and NF-кB-inducible kinase (NIK), and decreased the expression of IKB and IL-2 in mice [145]. They stated that the signaling pathway of liver injury in the $\mathrm{TiO}_{2}$ NPs-stimulated mouse liver sequentially might occur via activation of TLRs $\rightarrow$ NIK $\rightarrow$ IкB kinase $\rightarrow$ NF-кB $\rightarrow$ TNF- $\alpha \rightarrow$ inflammation $\rightarrow$ apoptosis $\rightarrow$ liver injury. Another intra-gastric administration study focusing on the molecular mechanisms of kidney injury of mice, found that $\mathrm{TiO}_{2}$ NPs (5-6 nm; 2.5, 5, and $10 \mathrm{mg} / \mathrm{kg}$; everyday for 90 days) activated NF- $\mathrm{kB}$, leading to increased expression of TNF- $\alpha$, MMIF, Il-2, Il-4, Il-6, Il-10, Il-18, Il-1 $\beta$, cross-reaction protein, TGF- $\beta$, interferon- $\gamma$, and CYP1A1, and a decrease in Hsp70 [146]. This showed that $\mathrm{TiO}_{2}$ NPs accumulate in the kidney, causing nephric inflammation, cell necrosis and dysfunction. Activation of NF- $\mathrm{KB}$ and increases in the expression of similar inflammatory cytokines were observed in a study by Sun et al. [147] after intratracheal instillation of $\mathrm{TiO}_{2}$ NPs (2.5, 5, and $10 \mathrm{mg} / \mathrm{kg} ; 90$ days) in mice. In addition, an increase in hemeoxygenase-1 (HO-1) expression and a decrease in NF-kB-inhibiting factor and Hsp70 expression were also observed. They suggested that the generation of pulmonary inflammation caused by $\mathrm{TiO}_{2}$ NPs $(5-6 \mathrm{~nm})$ in mice is closely related to oxidative stress and the expression of inflammatory cytokines. $\mathrm{TiO}_{2}$ NPs effectively activated caspase-3 and -9 , decreased gene and protein levels of Bcl-2, Bax and cytochrome c, and promoted ROS accumulation in mice spleen [148]. In this study mice were intraperitoneally injected with $\mathrm{TiO}_{2}$ NPs for 45 days consecutively. $\mathrm{TiO}_{2}$ NPs accumulated in the mouse spleen, leading to congestion and lymph nodule proliferation of spleen tissue, and splenocyte apoptosis. Taken together, this study indicated that $\mathrm{TiO}_{2} \mathrm{NPs}$ induce apoptosis in the mouse splenocyte via mitochondrialmediated pathway.

In regards to in utero genotoxicity, Jackson et al. [149] analyzed hepatic gene expression in newborns of C57BL/6BomTac dames exposed to $\mathrm{TiO}_{2}$ (surface coated UV-Titan; $1 \mathrm{~h} /$ day; $42 \mathrm{mg}$ UV-Titan $/ \mathrm{m}^{3}$ ) using DNA microarrays. UV-Titan exposure did not induce DNA strand breaks in time-mated mice or their offspring. Even though there were changes in the expression of genes related to retinoic acid signaling in the females as indicated by transcriptional profiling of newborn livers. They concluded that the changes may be a secondary response to maternal inflammation although no direct link was evident through gene expression analysis. Another inhalation study on female C57BL/6BomTac mice (UVTitan; $20 \mathrm{~nm}$; 1h/day for 11 consecutive days; 42.4 \pm 2.9 mg surface-coated nanoTiO $2 / \mathrm{m}^{3}$; sacrificed 5 days following the last exposure) showed that nanoTiO $\mathrm{Ti}_{2}$ exposure resulted in increased levels of mRNA for acute phase markers. serum amyloid A-1 (Saa1) and serum amyloid A-3 (Saa3), several CXC and CC chemokines, and cytokine tumor necrosis factor genes [150]. Further protein analysis of Saa1 and 3 showed selective upregulation of Saa3 in lung tissues. They also showed the up-regulation of miR-1, miR-449a and a 60-fold induction of miR-135b. They concluded that inhalation of surface-coated nanoTiO $\mathrm{Ti}_{2}$ results in changes in the expression of genes associated with acute phase, inflammatory and immune response 5 days post exposure with concomitant changes in several miRNAs.

However, not all studies showed genotoxic effects. A study investigating the effects of NPs on the female germline found that $\mathrm{TiO}_{2} \mathrm{NPs}$ (UV-Titan) do not induce expanded simple tandem repeat (ESTR) loci mutations in the germline of prenatally exposed female mice [151]. In this study, pregnant C57BL/6 mice were exposed by whole-body inhalation to the $\mathrm{TiO}_{2}$ NPs (UV-Titan L181; $\sim 42.4 \mathrm{mg} / \mathrm{m}^{3}$ ) on gestation days (GD) $8-18$. F2 descendents were collected and ESTR germline mutation rates in this generation were estimated from full pedigrees (mother, father, and offspring) of F1 female mice (192 UV-Titan-exposed F2 offspring and 164F2 controls). Most of these studies were carried out on C57BL/6 mice strains. The positive endpoints of interest were polychromatic erythrocyte (PCE) micronuclei, $\gamma$-H2AX foci formation, DNA damage, HPRT mutation frequency and mRNA expression. However, some PCE micronuclei and 
ESTR mutations were not positive. An inhalation exposure (C57BL/6J mice; treated with $0.8,7.2$, and $28.5 \mathrm{mg} / \mathrm{cm}^{3}$ for 5 days; 4h/day) study by Lindberg et al. [152] showed no significant effect on the level of DNA damage in lung epithelial cells or micronuclei in bone marrow polychromatic erythrocytes (PCE's) by freshly prepared $\mathrm{TiO}_{2} \mathrm{NPs}$ (74\% anatase; $26 \%$ brookite). In addition, the rate of PCE MN cells induced in mice after oral administration of $\mathrm{TiO}_{2}$ NPs $(1,2$, and, $5 \mathrm{~g} / \mathrm{kg} \mathrm{BW})$ were also not significantly different from controls [115]. Another study stated that DNA adduct formation in rat lungs was not detected following chronic inhalation for two years to $\mathrm{TiO}_{2}$ NPs $\left(10.4 \mathrm{mg} / \mathrm{m}^{3}\right)$ [153].

The in vivo genotoxicity studies targeted different organs as well as the reproductive system show that the $\mathrm{TiO}_{2}$ NPs increased the expression of the inflammatory cytokines, the mRNA expression of toll like receptors, gene mutations of the HPRT, induction of $\gamma-\mathrm{H} 2 \mathrm{AX}$ foci, DNA deletions, and PCE. Increases in expression of $\mathrm{HO}-1, \mathrm{NF}-\kappa \mathrm{B}$, and Hsp70 were also observed. However, some studies also show that $\mathrm{TiO}_{2}$ NPs were not genotoxic. These disparities in results may be due to the differences in the physicochemical characteristics of the $\mathrm{TiO}_{2}$ NPs used, or the exposure metrics used by the investigators.

\section{In vitro studies}

Many in vitro studies have been conducted to investigate the genotoxicity of $\mathrm{TiO}_{2}$ NPs. $\mathrm{TiO}_{2}$ NPs have also been observed around the nuclei in the vicinity of the endoplasmic reticulum in cultured human-derived retinal pigment epithelial cells (ARPE-19) after exposure to high concentrations $(30 \mu \mathrm{g} / \mathrm{ml})$ [154]. The studies that have been conducted have tried to compare effects $\mathrm{TiO}_{2} \mathrm{NPs}$ according to particle sizes, surface coatings, crystal structure, dose ranges, different cell lines, and exploratory studies.

Recently, a study by Jugan et al. [155] has shown that spherical $\mathrm{TiO}_{2}$ NPs (12-140 nm; both anatase and rutile) can induce single strand breaks, oxidative lesions to DNA and oxidative stress in A549 cells. They also showed that $\mathrm{TiO}_{2}$ NPs impair the cell's ability to repair DNA by deactivation of both nucleotide excision repair (NER) and base excision repair (BER) pathways. Others have also found that $\mathrm{TiO}_{2}$ NPs cause increased extracellular ROS, HO-1, and NOS mRNA expression and TNF- $\alpha$ release in NR8383 rat lung alveolar macrophages [93]. $\mathrm{TiO}_{2}$ NPs demonstrated cytotoxic and genotoxic effects in human amnion epithelial (WISH) cells in another recent study [156]. In this study, polyhedral rutile $\mathrm{TiO}_{2}$ NPs $(30.6 \mathrm{~nm} ; 20 \mu \mathrm{g} / \mathrm{ml})$ caused a 14 fold increase in olive tail moment (OTM), while cells treated with $0.625-10 \mu \mathrm{g} / \mathrm{ml}$ exhibited significant reduction in catalase activity and GSH level. There was a 1.87 fold increase in intracellular ROS generation and 7.3\% increase in $\mathrm{G}_{2} \mathrm{M}$ cell cycle arrest.

Bhattacharya et al. [157] reported that human lung fibroblasts were more sensitive regarding cyto- and genotoxic effects caused by $\mathrm{TiO}_{2}$ NPs than human bronchial epithelial (BEAS-2B) cells. In this study, $\mathrm{TiO}_{2} \mathrm{NPs}$ induced oxidative stress and DNA-adduct formation (8OHdG) but not DNA-breakage in human lung fibroblasts. Hamster lung fibroblasts (V79 cells) were used in a study focusing on cyto- and genotoxic effects of $\mathrm{TiO}_{2}$ NPs (untreated anatase; $30-50 \mathrm{~nm}$ ) and vanadium pentoxide $\left(\mathrm{V}_{2} \mathrm{O}_{5}\right)$-treated anatase particles [158]. $\mathrm{V}_{2} \mathrm{O}_{5^{-}}$ treated $\mathrm{TiO}_{2}$ NPs were capable of inducing greater DNA damage in mammalian cells through production of free radicals than untreated particles. $\mathrm{V}_{2} \mathrm{O}_{5}$-treated $\mathrm{TiO}_{2} \mathrm{NPs}$ formed pronounced acellular and cellular radicals of interest. Surface-treated $\mathrm{TiO}_{2}$ NPs particles coated with $\mathrm{V}_{2} \mathrm{O}_{5}$ are used industrially for selective catalytic reactions such as the removal of nitrous oxide from exhaust gases of combustion power plants (SCR process) and in biomaterials for increasing the strength of implants.

Wang et al. [30] detected genotoxicity of $\mathrm{TiO}_{2} \mathrm{NPs}$ in cultured human lymphoblastoid cells using the cytokinesis block micronucleus (CBMN) assay, the Comet assay, and the HPRT gene mutation assay. The cells were incubated for 6,24 and $48 \mathrm{~h}$ with $0,26,65$ or $130 \mu \mathrm{g} / \mathrm{ml}$ $\mathrm{TiO}_{2}$ NPs $(7-8 \mathrm{~nm}) . \mathrm{TiO}_{2} \mathrm{NPs}$ induced approximately a 2.5 -fold increase in the frequency of micronucleated/ binucleated cells $(130 \mu \mathrm{g} / \mathrm{ml})$, approximately a 5 -fold increase in tail moment $(65 \mu \mathrm{g} / \mathrm{ml})$, and approximately a 2.5 fold increase in the HPRT mutation frequency $(130 \mu \mathrm{g} / \mathrm{ml}) . \mathrm{TiO}_{2}$ anatase NPs and larger rutile particles provoked higher IL-1 $\beta$ production in macrophage-like human THP-1 cells [159]. A study on human monoblastoid cell line (U937) found that $\mathrm{TiO}_{2}$ NPs $(<100 \mathrm{~nm})$ induced both apoptotic and necrotic modifications at exposures of $0.005-4 \mathrm{mg} / \mathrm{ml}$ for 24 and $48 \mathrm{~h}$ [160]. Another study aimed at validating in vitro test systems for apoptosis induced by NPs found that TiO2 NPs induced DNA fragmentation in RAW264.7 macrophages [161]. While in cultured human lymphocytes $\mathrm{TiO}_{2}$ NPs increased the proportion of sub-G1 cells, activated caspase- 9 and caspase- 3 , and induced caspase-3-mediated PARP cleavage [162]. Time-sequence analysis of the induction of apoptosis revealed that $\mathrm{TiO}_{2}$ NPs triggered apoptosis through caspase-8/Bid activation. They stated that $\mathrm{TiO}_{2}$ NPs induced apoptosis is mediated by the p38/JNK pathway and the caspase-8-dependent Bid pathway in human lymphocytes. However, in a study conducted on BEAS 2B cells, Shi et al. [163] noted that $\mathrm{TiO}_{2}$ NPs induced apoptosis via the mitochondrial apoptosis pathway independent of caspase 8/t-Bid pathway. These results show that different cell lines exhibit different responses to $\mathrm{TiO}_{2}$ NPs. 
Another study on human lymphocytes showed that, $\mathrm{TiO}_{2}$ NPs significantly increased $\mathrm{MN}$ formation and DNA breakage [164]. The generation of ROS in $\mathrm{TiO}_{2}$ NP-treated cells was also observed. N-acetylcysteine (NAC) supplementation inhibited the level of $\mathrm{TiO}_{2} \mathrm{NP}-$ induced DNA damage. The inhibitive nature of NAC on ROS formation in cells exposed to $\mathrm{TiO}_{2}$ was also noted by Xue et al. [165]. Shukla et al. [28] also demonstrated ROS involvement in oxidative DNA damage and MN formation in human epidermal cells. Ghosh et al. [166] investigated the genotoxicity of $\mathrm{TiO}_{2} \mathrm{NPs}$ in plant and human lymphocytes using classical genotoxic endpoints: Comet assay and the DNA laddering technique. $\mathrm{TiO}_{2}$ NPs were found to be genotoxic at a low dose of 0.25 $\mathrm{mM}$ followed by a decrease in the extent of DNA damage at higher concentrations. In contrast, $\mathrm{TiO}_{2}$ FPs were consistently genotoxic at doses of $1.25 \mathrm{mM}$ and above. This study concluded that the $\mathrm{TiO}_{2}$ NPs possess genotoxic potential in plant and human lymphocytes. These results imply that genotoxic effects of $\mathrm{TiO}_{2} \mathrm{NPs}$ may occur through ROS generation in lymphocytes.

Uncoated $\mathrm{TiO}_{2}$ anatase NPs (99.7\%; <25 nm) and $\mathrm{TiO}_{2}$ rutile FPs $(99.9 \%$; $<5 \mu \mathrm{m})$ were shown to be more efficient than $\mathrm{SiO}_{2}$-coated $\mathrm{TiO}_{2}$ rutile NPs (>95\%, <5\% amorphous $\mathrm{SiO}_{2}$ coating; $10 \times 40 \mathrm{~nm}$ ) in inducing DNA damage, whereas only $\mathrm{TiO}_{2}$ anatase NPs were able to slightly induce micronuclei in a study by Falck et al. [167] on BEAS 2B cells $\left(1-100 \mu \mathrm{g} / \mathrm{cm}^{2} ; 24,48\right.$, and 72 h). The lower activity of nano sized rutile in genotoxicity is likely due to its coating. This conclusion is supported by Mano et al. [168]. They found that when $\mathrm{TiO}_{2} \mathrm{NPs}$ (P25; $25 \mathrm{~nm} ; 80 / 20$ anatase/rutile) were coated with polyethylene glycol (PEG), their cytotoxic effects and induction of stress related genes in human pulmonary epithelial (NCI-H292) cells and human acute monocytic leukemia (THP-1) cells significantly decreased. Analysis of mRNA expression indicated that the expression of particular biomarkers depends upon the cell type, and that modification of $\mathrm{TiO}_{2}$ NPs with PEG reduces their cytotoxicity and reduces the induction of genes associated with stress and toxicity.

Petkovic et al. [21] investigated the genotoxic responses to two types of $\mathrm{TiO}_{2}$ NPs $(<25 \mathrm{~nm}$ anatase: $\left.\mathrm{TiO}_{2}-\mathrm{An}\right)$ and $\left(<100 \mathrm{~nm}\right.$ rutile: $\left.\mathrm{TiO}_{2}-\mathrm{Ru}\right)$ in human hepatoma HepG2 cells. They found that $\mathrm{TiO}_{2}-\mathrm{An}$, caused a persistent increase in DNA strand breaks (Comet assay) and oxidized purines (Fpg-Comet). Both types transiently upregulated mRNA expression of p53 and its downstream regulated DNA damage responsive genes (mdm2, gadd $45 \alpha$, and p21). A recent study conducted with Caco- 2 cells found that in contrast to pure anatase $\mathrm{TiO}_{2}$ NPs, anatase/rutile $\mathrm{TiO}_{2}$ NPs induced significant LDH leakage and mild DNA damage as shown by the fpg-Comet assay [169]. The anatase/rutile
NPs also showed higher toxicity per unit surface area. The investigators used the WST-1 assay to show that there was highly significant correlation between the specific surface area of anatase and cytotoxicity.

Gurr et al. [170] investigated the oxidative damage induced by $\mathrm{TiO}_{2}$ NPs in the absence of photo-activation in BEAS $2 \mathrm{~B}$ cells. Results indicated that $\mathrm{TiO}_{2}$ NPs (anatase; 10 and $20 \mathrm{~nm}$ ) in the absence of photo-activation induced oxidative DNA damage, LPO, and micronuclei formation. However, treatment with $\mathrm{TiO}_{2}$ FPs (anatase; $>200 \mathrm{~nm}$ ) did not. Huang et al. [171] investigated the cell transformation mediated by long-term exposure to $\mathrm{TiO}_{2}$ NPs and found that $\mathrm{TiO}_{2}$ NPs not only increased cell survival and growth in soft agar but also the numbers of multinucleated cells and MN. To study the potential of fine $(>200 \mathrm{~nm})$ and nano $\mathrm{TiO}_{2}$ particle $(\leq 20$ $\mathrm{nm}$ ) to induce chromosomal changes, Rahman et al. [172] treated SHE cells with $1.0 \mu \mathrm{g} / \mathrm{cm}^{2}$ of $\mathrm{TiO}_{2}$ particle for $12-72 \mathrm{~h}$. The micronuclei assay revealed a significant increase in $\mathrm{MN}$ induction in SHE cells after NP treatment, whereas $\mathrm{TiO}_{2}$ FPs did not show significant induction of $\mathrm{MN}$ formation. However, other investigators who used the same cell line have stated that cytotoxicity and genotoxicity induced by metal oxide NPs are not always higher than those induced by their FP counterparts $\left(14-35 \mathrm{~nm} ; 5,10\right.$, and $\left.50 \mu \mathrm{g} / \mathrm{cm}^{2}\right)$ [173]. Lu et al. [140] found $\mathrm{TiO}_{2}$ particles (sizes not reported) to be toxic to Chinese hamster ovary- $\mathrm{K} 1$ (CHO-K1) cells. The sister chromatid exchange (SCE) frequency and $\mathrm{MN}$ frequency in CHO-K1 cells treated with $\mathrm{TiO}_{2}$ particles $(0-5$ $\mu \mathrm{M})$ for $24 \mathrm{~h}$ exhibited a significant and dose-dependent increase in genotoxicity. Their findings are supported by Di Virgilio et al. [174] who also had similar results in CHO-K1 cells. Genotoxic effects were shown by $\mathrm{MN}$ frequencies, which significantly increased at 0.5 and $1 \mu \mathrm{g} / \mathrm{ml}$ of $\mathrm{TiO}_{2}$ NPs. SCE frequencies were higher for cells treated with 1-5 $\mu \mathrm{g} / \mathrm{ml}$ of $\mathrm{TiO}_{2}$ NPs. Conversely, a chronic (60 days) study with $\mathrm{CHO}$ cells $\left(0,10,20\right.$, and $\left.40 \mu \mathrm{g} / \mathrm{cm}^{2}\right)$ showed no cyto or genotoxic effects by $\mathrm{TiO}_{2}$ NPs $(100 \%$ anatase, $25 \mathrm{~nm})$ [175]. They stated that $\mathrm{CHO}$ cells adapted to chronic exposure and detoxified the excess ROS possibly through upregulation of superoxide dismutase (SOD).

A recent study found that $\mathrm{TiO}_{2}$ NPs (aeroxide P-25 99.5\% 73-85\% anatase, $14-17 \%$ rutile, and $2-13 \%$ amorphous) were cytotoxic and genotoxic to human skin fibroblast cell line in a dose dependent manner (10, $25,50,100,250,500$, and $1000 \mu \mathrm{g} / \mathrm{ml}$ ) using the test for $\gamma$-H2AX expression [176]. Another study specifically targeted the relationship between $\mathrm{TiO}_{2}$ NPs and the DNA damage response pathways regulated by ATM/ $\mathrm{Chk}_{2}$ and ATR/Chk1 in human dermal fibroblasts [177]. Their results showed increased phosphorylation of $\mathrm{H} 2 \mathrm{AX}$, ATM, and $\mathrm{Chk}_{2}$ after exposure. In addition, $\mathrm{TiO}_{2}$ NPs inhibited the overall rate of DNA synthesis and 
frequency of replicon initiation events in DNA-combed fibres. Taken together, these results demonstrate that exposure to $\mathrm{TiO}_{2}$ NPs activates the ATM/Chk 2 DNA damage response pathway.

The interaction of $\mathrm{TiO}_{2}$ NPs with liver DNA from ICR mice was systematically studied in vivo using ICP-MS, various spectral methods and gel electrophoresis [178]. The results showed that the liver weights of the mice treated with higher amounts of anatase $\mathrm{TiO}_{2}$ NPs were significantly increased. They stated that anatase $\mathrm{TiO}_{2}$ NPs could have accumulated in liver DNA by inserting itself into DNA base pairs or binding to DNA nucleotide that bound with three oxygen or nitrogen atoms and two phosphorous atoms of DNA with the $\mathrm{Ti}-\mathrm{O}(\mathrm{N})$ and Ti-P bond lengths of 1.87 and $2.38 \mathrm{~A}$, respectively, and could alter the conformation of DNA. The gel electrophoresis showed that higher dose of nano-anatase $\mathrm{TiO}_{2}$ NPs could cause liver DNA cleavage in mice.

However, as stated in the in vivo studies section, there are also studies that imply the opposite. A recent study found that $\mathrm{TiO}_{2}$ NPs (28 nm; 90/10: anatase/rutile) did not induce ROS production or increase the expression of $\gamma$-H2AX in A549 cells $(0,2.5,5,10,15,20$, and $40 \mu \mathrm{g} /$ $\mathrm{ml}$; 24h) [179]. The transcription and protein expression levels of two Hsp members, Grp78 and Hsp70, were evaluated to ascertain their suitability as biomarkers of $\mathrm{TiO}_{2}$ NP-induced toxicity in the respiratory system [180]. Even though the presence of $\mathrm{TiO}_{2}$ NPs $(25 \mathrm{~nm})$ was confirmed in the cells via ultra-structural observations leading to cell death and induction of intracellular ROS generation, the transcription and protein expression levels of Hsp70 and Grp78 did not change at the same dose range $(25-500 \mu \mathrm{g} / \mathrm{ml})$ in A549 cells. They concluded that Hsp70 and Grp78 are not suitable biomarkers for evaluating the acute toxicological effects of $\mathrm{TiO}_{2}$ NPs in the respiratory system.

A recent study by Woodruff et al. [181] found that $\mathrm{TiO}_{2}$ NPs (10 nm anatase spheres; non-coated; 0-200 $\mu \mathrm{g}$ $/ \mathrm{ml} ; 24 \mathrm{~h}$ ) were not genotoxic under the conditions of the Ames test and Comet assay in the thymidine kinase heterozygote (TK6) cell lines. There was no significant DNA damage or oxidative DNA damage observed. Warheit et al. [114] also reported negative results for an in vitro mammalian chromosome aberration test on Chinese hamster ovary cells $(\mathrm{CHO})$ treated with $\mathrm{TiO}_{2}$ NPs (metaphase at 750, 1250, and $2500 \mu \mathrm{g} / \mathrm{ml} 4 \mathrm{~h}$ nonactivated test condition; at $62.5,125,250 \mu \mathrm{g} / \mathrm{ml}, 4 \mathrm{~h}$ activated test condition, and at 25, 50, $100 \mu \mathrm{g} / \mathrm{ml} 20 \mathrm{~h}$ nonactivated test condition). Linnainmaa et al. [182] reported similar negative results in cultured rat liver epithelial cells using the $\mathrm{MN}$ assay. Their results suggest that both $\mathrm{TiO}_{2}$ FPs and NPs $\left(5,10\right.$, and $\left.20 \mu \mathrm{g} / \mathrm{cm}^{2}\right)$ have no direct clastogenic potential. Fisichella et al. [183] concluded in their study that surface treated $\mathrm{TiO}_{2} \mathrm{NPs}$
$(100 \mu \mathrm{g} / \mathrm{ml}$ of STNP for 4,24 , and $72 \mathrm{~h}$ ) with a rutile core $(7 \pm 2 \mathrm{~nm} \times 50 \pm 10 \mathrm{~nm})$ are not harmful to Caco-2 cells. In $\mathrm{TiO}_{2}$ NP-induced inflammation, NF- $\mathrm{kB}$ is thought to be activated in response to pro-inflammatory cytokines. However, a recent study by Wilson et.al [184] showed that after $6 \mathrm{~h}$ incubation with P-25 (10, 50, and $250 \mu \mathrm{g} / \mathrm{ml}$ ), NF- $\mathrm{kB}$ was not activated in A549 cells. They concluded that NF-kB DNA binding may not be the likely transcription pathway that leads to $\mathrm{TiO}_{2}$ NPinduced inflammation. $\mathrm{TiO}_{2} \mathrm{NPs}$ also were found to have no effect on the regulation of plasminogen activator inhibitor-1 expression in endothelial cells [185]. $\mathrm{TiO}_{2} \mathrm{NPs}$ did not cause an increase in pro-mitochondrial membrane potential (MMP)-2 and pro-MMP-9 gelatinolytic activities in conditioned media, there was no dose- and timerelated decreases in tissue inhibitors of metalloproteinases 2 (TIMP-2) and no transcriptional change of TIMP-1 were observed in U937 cells [186].

In summary, many in vivo and in vitro studies were conducted to investigate the genotoxicity of $\mathrm{TiO}_{2}$ FPs and NPs, but results are conflicting. Some studies indicate that $\mathrm{TiO}_{2}$ NPs are genotoxic, whereas the others give negative results. Even though the rationale for these conflicting results is not clear, use of different cell types, exposure metrics, crystalline structure, particle dispersion and NP sizes may be an explanation. Most of the cell lines which show genotoxicity are cells associated with the respiratory system and the circulatory system. Overall, the studies indicating that $\mathrm{TiO}_{2}$ NPs are genotoxic outweigh the studies that state otherwise. Thus, $\mathrm{TiO}_{2}$ NPs can be treated as potential hazards. More studies are needed to determine the conditions in which $\mathrm{TiO}_{2}$ NPs genotoxicity occurs [32]. The possible mechanisms for $\mathrm{TiO}_{2}$ NP-induced genotoxicity involve DNA damage directly or indirectly via oxidative stress and/or inflammatory responses. Tables 1 and 2 give a summary of the genotoxicity studies mentioned in this paper.

\section{Reproductive and developmental toxicity}

Although experimental evidence shows that absorbed $\mathrm{TiO}_{2}$ particles may be able to move across the placenta into fetal tissue, it has not yet been established whether human exposure to $\mathrm{TiO}_{2}$ particles causes reproductive and developmental toxicities. Exposure of other species, such as zebra fish [187] and abalone embryo [113], to $\mathrm{TiO}_{2}$ particles have shown that it can impair reproduction, inhibit hatching, and cause malformations. However, in the case of zebra fish some disagree [188]. In mammals, limited animal data are available to define the developmental or reproductive toxicity of $\mathrm{TiO}_{2} \mathrm{NPs}$. With respect to in vivo studies, Takeda et al. [189] demonstrated that prenatal subcutaneous exposure of mice to $\mathrm{TiO}_{2}$ NPs (25 and $70 \mathrm{~nm} ; 16 \mathrm{mg} / \mathrm{kg}$ ) at day 3, 7, 10, and 14 can damage the genital and cranial nerve systems in the 
Table 1 Genotoxicity of $\mathrm{TiO}_{2}$ NPs in vivo studies

\begin{tabular}{|c|c|c|c|c|c|}
\hline $\begin{array}{l}\text { Reference } \\
\text { No. }\end{array}$ & Crystalline structure & Exposure mode & Dose & Test type & Result \\
\hline \multirow[t]{6}{*}{ [32] } & \multirow[t]{6}{*}{ P25 (75\% anatase, $25 \%$ rutile) } & \multirow{6}{*}{$\begin{array}{l}\text { Drink water } \\
\text { (C57BI/6Jmice) }\end{array}$} & \multirow[t]{6}{*}{$60,120,300$, and $600 \mu \mathrm{g} / \mathrm{ml}$} & Comet assay & $(+)$ \\
\hline & & & & Micronuclei assay (PCE) & $(+)$ \\
\hline & & & & $\mathrm{\gamma}-\mathrm{H} 2 \mathrm{AX}$ assay & $(+)$ \\
\hline & & & & Immunostaining assay & $(+)$ \\
\hline & & & & RT-PCR(TNF- $a$, IFN- $\gamma$, IL8) & $(+)$ \\
\hline & & & & RT-PCR(TGF- $\beta$, IL-10, IL-4) & $(-)$ \\
\hline [115] & Nano-TiO ${ }^{2}$ & intragastric administration & 100,1000, and $5000 \mathrm{mg} / \mathrm{kg}$ & Micronuclei assay (PCE) & $(-)$ \\
\hline [142] & $(20 \mathrm{~nm})$, rutile $(80 \mathrm{~nm})$ & $\begin{array}{l}\text { Inhalation } \\
\text { (C57BL/6J mice) }\end{array}$ & $200 \mu \mathrm{g} / \mathrm{ml}$ & ELISA assay (IL-1a, IL-1 $\beta, \| L-6$, and TNF) & $(+)$ \\
\hline \multirow[t]{2}{*}{ [145] } & \multirow[t]{2}{*}{ Anatase } & \multirow[t]{2}{*}{$\begin{array}{l}\text { Inhalation } \\
\text { (ICR mice) }\end{array}$} & \multirow[t]{2}{*}{$0,5,10$, and $50 \mathrm{mg} / \mathrm{kg}$} & $\begin{array}{l}\text { RT-PCR (IKK1, IKK2, NF-KB, NF-KBP52, } \\
\text { NF-KBP65, TNF-a, and NIK) }\end{array}$ & $(+)$ \\
\hline & & & & $\begin{array}{l}\text { ELISA (IKK1, IKK2, NF-KB, NF-KBP52, } \\
\text { NF-KBP65, TNF-a, and NIK) }\end{array}$ & $(+)$ \\
\hline \multirow[t]{2}{*}{ [146] } & \multirow[t]{2}{*}{ Anatase } & \multirow[t]{2}{*}{$\begin{array}{l}\text { Intragastric administration } \\
\text { (ICR mice) }\end{array}$} & \multirow[t]{2}{*}{$0,2.5,5,10 \mathrm{mg} / \mathrm{kg}$} & $\begin{array}{l}\text { mRNA expression (NF-kB, TNF- } a \text {, } \\
\text { Hsp70, IL-1a, MIF, INF- } \gamma \text {, TGF- } \beta \text {, CRP, } \\
\text { CYP1A, IL-4,6,8,10,18) }\end{array}$ & $(+)$ \\
\hline & & & & $\begin{array}{l}\text { ELISA (NF-kB, TNF- } a, \text { Hsp70, IL-1a, } \\
\text { MIF, INF- } \gamma, \text { TGF- } \beta \text {, CRP, CYP1A, } \\
\text { IL-4,6,8,10,18) }\end{array}$ & $(+)$ \\
\hline \multirow[t]{2}{*}{ [147] } & \multirow[t]{2}{*}{ Anatase } & \multirow[t]{2}{*}{$\begin{array}{l}\text { Intratracheal instillation } \\
\text { (ICR mice) }\end{array}$} & \multirow[t]{2}{*}{$0,2.5,5,10 \mathrm{mg} / \mathrm{kg}$} & $\begin{array}{l}\text { RT-PCR (NF-KB, IKB, TNF-a, IL-2, IL-4, } \\
\text { IL-6, IL-8, IL-10, IL-18, IL-6, IL-1a, COX-2, } \\
\text { HO-1, CYP1A1 and HSP-70) }\end{array}$ & $(+)$ \\
\hline & & & & $\begin{array}{l}\text { ELISA (NF-kB, IKB, TNF-a, IL-2, IL-4, } \\
\text { IL-6, IL-8, IL-10, IL-18, IL-6, IL-1a, } \\
\text { COX-2, HO-1, CYP1A1 and HSP-70) }\end{array}$ & $(+)$ \\
\hline \multirow[t]{2}{*}{ [148] } & \multirow[t]{2}{*}{ Anatase, $100 \%$} & \multirow[t]{2}{*}{$\begin{array}{l}\text { Intraperitoneal injection } \\
\text { (ICR mice) }\end{array}$} & \multirow[t]{2}{*}{$0,5,50,150 \mathrm{mg} / \mathrm{kg}$} & $\begin{array}{l}\text { RT-PCR (caspase-3, caspase-9, Bax, } \\
\text { Bcl-2, and cytochrome c) }\end{array}$ & $(+)$ \\
\hline & & & & $\begin{array}{l}\text { ELISA (caspase-3, caspase- } 9 \text {, Bax, Bcl-2, } \\
\text { and cytochrome c) }\end{array}$ & $(+)$ \\
\hline \multirow[t]{3}{*}{ [149] } & \multirow[t]{3}{*}{ UV-Titanium (rutile, 17 nm) } & \multirow{3}{*}{$\begin{array}{l}\text { Inhalation } \\
\text { (C57BL/6BomTac mice) }\end{array}$} & \multirow[t]{3}{*}{$42 \mathrm{mg} / \mathrm{m}^{3}$} & DNA strand breaks & $(-)$ \\
\hline & & & & $\begin{array}{l}\text { DNA microarrays (Cyp26b1, Ttr, } \\
\text { and Ugt3a2) }\end{array}$ & $(+)$ \\
\hline & & & & RT-PCR (Cyp26b1, Ttr, and Ugt3a2) & $(-)$ \\
\hline \multirow[t]{3}{*}{ [150] } & \multirow[t]{3}{*}{$\begin{array}{l}\text { P20 (coated with } \\
\text { polyalcohol) }\end{array}$} & \multirow[t]{3}{*}{$\begin{array}{l}\text { Inhalation } \\
\text { (C57BL/6BomTac mice) }\end{array}$} & \multirow[t]{3}{*}{$42.4 \mathrm{mg} / \mathrm{m}^{3}$} & $\begin{array}{l}\text { Gene Expression Analysis (Copine5, } \\
\text { Saa1, and Saa3) }\end{array}$ & $(-)$ \\
\hline & & & & DNA microarray & $(-)$ \\
\hline & & & & $\begin{array}{l}\text { PCR (cxcl-5, cxcl1, ccl2, ccl22, ccl7, } \\
\text { ccr4, and TNF) }\end{array}$ & $(+)$ \\
\hline [151] & $\begin{array}{l}\text { UV-Titanium (coated with } \\
\text { polyalcohol, 20.6nm) }\end{array}$ & $\begin{array}{l}\text { Inhalation } \\
\text { (C57BL/6J mice) }\end{array}$ & $42.4 \mathrm{mg} / \mathrm{m}^{3}$ & $\begin{array}{l}\text { Expanded simple tandem repeat } \\
\text { (ESTR) assays }\end{array}$ & $(-)$ \\
\hline \multirow[t]{2}{*}{ [152] } & \multirow[t]{2}{*}{$\mathrm{TiO}^{2}(97 \%)$} & \multirow{2}{*}{$\begin{array}{l}\text { Inhalation } \\
\text { (C57BL/6J mice) }\end{array}$} & \multirow[t]{2}{*}{$0,0.8,7.2,28.5 \mathrm{mg} / \mathrm{m}^{3}$} & Micronuclei assay (PCE) & $(-)$ \\
\hline & & & & Comet assay & $(-)$ \\
\hline [153] & P25 (15 nm, ultrafine) & $\begin{array}{l}\text { Inhalation } \\
\text { (Wistar rats) }\end{array}$ & $10.4 \mathrm{mg} / \mathrm{m}^{3}$ & DNA adduct & $(+)$ \\
\hline [178] & Anatase & $\begin{array}{l}\text { Intraperitioneal injection } \\
\text { (ICR mice) }\end{array}$ & $\begin{array}{l}0,5,10,50,100, \text { and } \\
150 \mathrm{mg} / \mathrm{kg}\end{array}$ & DNA damage & $(+)$ \\
\hline
\end{tabular}

(+) Positive; (-) Negative.

offspring. In this study, $\mathrm{TiO}_{2}$ NPs identified by energydispersive X-ray spectroscopy were found in the testes and brain of exposed 6-week-old male mice, which indicated that $\mathrm{TiO}_{2}$ NPs may penetrate both blood-testis and BBB. Shimizu et al. [88] reported that, in the brain tissue of male fetuses (embryonic day 16) and pups (postnatal days 2, 7, 14, and 21), subcutaneous injection of pregnant mice $\left(100 \mu \mathrm{l} \mathrm{TiO}_{2}\right.$ NPs suspended at $\left.1 \mu \mathrm{g} / \mu \mathrm{l}\right)$ 
Table 2 Genotoxicity of $\mathrm{TiO}_{2} \mathrm{NPs}$ in vivo studies

\begin{tabular}{|c|c|c|c|c|c|}
\hline Reference No. & Crystalline structure & Exposure mode & Concentration & Test type & Result \\
\hline \multirow[t]{6}{*}{ [21] } & \multirow[t]{3}{*}{ Anatase } & \multirow[t]{6}{*}{ HepG2 cells } & \multirow{6}{*}{$\begin{array}{l}0,1,10,100 \text { and } 250 \\
\mu \mathrm{g} / \mathrm{ml} \text { of } \mathrm{TiO}^{2} \mathrm{NPs}\end{array}$} & Comet assay & $(+)$ \\
\hline & & & & Fpg-Comet & $(+)$ \\
\hline & & & & Upregulated mRNA expression (p53) & $(+)$ \\
\hline & \multirow[t]{3}{*}{ Rutile } & & & Comet assay & $( \pm)$ \\
\hline & & & & Fpg-Comet & $( \pm)$ \\
\hline & & & & Upregulated mRNA expression (p53, mdm2, p21 and gadd45a) & $(+)$ \\
\hline [28] & Anatase, 99.7\% & A431 cells & $\begin{array}{l}0.008-80 \mu \mathrm{g} / \mathrm{ml}(10 \\
\text { times) }\end{array}$ & Comet assay & $(+)$ \\
\hline \multirow[t]{3}{*}{ [30] } & \multirow[t]{3}{*}{$\mathrm{TiO}^{2}$ NPs (99\% pure) } & \multirow{3}{*}{$\begin{array}{l}\text { Human lymph- oblastoid } \\
\text { cells }\end{array}$} & \multirow[t]{2}{*}{$130 \mu \mathrm{g} / \mathrm{ml}$} & Cytokinesis-block micronucleus (CBMN) assays & $(+)$ \\
\hline & & & & HPRT mutation assay & $(+)$ \\
\hline & & & $65 \mu \mathrm{g} / \mathrm{ml}$ & Comet assay & $(+)$ \\
\hline \multirow[t]{2}{*}{ [93] } & \multirow[t]{2}{*}{ Anatase/Rutile, 80/20 } & \multirow{2}{*}{$\begin{array}{l}\text { NR8383 rat lung alveolar } \\
\text { macrophages }\end{array}$} & \multirow[t]{2}{*}{$0,10,20,40,80 \mu \mathrm{g} / \mathrm{cm}^{2}$} & qRT-PCR (HO-1) & $(+)$ \\
\hline & & & & Immunocytochemistry (NF-kB) & $(+)$ \\
\hline [114] & Rutile & $\mathrm{CHO}$ cells & $0,25,50,100 \mu \mathrm{g} / \mathrm{ml}$ & Mammalian chromosome aberration test & $(+)$ \\
\hline \multirow[t]{3}{*}{ [155] } & \multirow[t]{3}{*}{ Spherical (anatase \& rutile) } & \multirow[t]{3}{*}{ A549 cells } & \multirow[t]{3}{*}{$100 \mu \mathrm{g} / \mathrm{ml}$} & Single strand breaks Comet assay & $(+)$ \\
\hline & & & & HPLC-MS/MS & $(+)$ \\
\hline & & & & 8-oxodCuo & $(+)$ \\
\hline \multirow[t]{3}{*}{ [156] } & \multirow[t]{3}{*}{ P30.6 } & \multirow[t]{3}{*}{ WISH cells } & \multirow[t]{3}{*}{$0.625-20 \mu \mathrm{g} / \mathrm{ml}$} & Olive tail moment & $(+)$ \\
\hline & & & & ROS generation & $(+)$ \\
\hline & & & & Cell cycle arrest & $(+)$ \\
\hline \multirow[t]{2}{*}{ [157] } & \multirow[t]{2}{*}{ Anatase $(<100 \mathrm{~nm})$} & \multirow[t]{2}{*}{ IMR90 cells BEAS-2B cells } & \multirow[t]{2}{*}{$0,2,5,10,50 \mu \mathrm{g} / \mathrm{cm}^{2}$} & Olive tail moment & $(-)$ \\
\hline & & & & DNA breaks & $(-)$ \\
\hline \multirow[t]{3}{*}{ [158] } & \multirow[t]{2}{*}{$\mathrm{V}_{2} \mathrm{O}_{5}$ treated $\mathrm{TiO}^{2}$ anatase } & \multirow[t]{2}{*}{ V79 cells } & \multirow[t]{2}{*}{$0,1,5,10,15,25 \mu \mathrm{g} / \mathrm{cm}^{2}$} & Micronucleus test & $(+)$ \\
\hline & & & & DNA damage & $(+)$ \\
\hline & Untreated anatase & & & & \\
\hline [159] & Spherical (anatase) Spicular (rutile) & THP-1 cells & $0,20,100,500 \mu \mathrm{g} / \mathrm{ml}$ & ROS & $(+)$ \\
\hline [160] & Anatase, 99\% & U937 cells & $0.005-4 \mathrm{mg} / \mathrm{ml}$ & DNA fragmentation & $(+)$ \\
\hline \multirow[t]{2}{*}{ [161] } & Anatase/rutile, 80/20 & RAW264.7 cells & $0,1,5,10,40$ or $80 \mu \mathrm{g} /$ & DNA fragmentation & $(+)$ \\
\hline & & & & ELISA (CDDE) & $(-)$ \\
\hline [162] & P25 (70-85\% Anatase, 30-15\% rutile) & Human perip- heral blood & $0,20,50,100 \mu \mathrm{g} / \mathrm{ml}$ & Flow cytometry of apoptosis & $(+)$ \\
\hline & & lympnocytes & & Western blot (cleaved caspase-8, $-3, \mathrm{Bid}$, and cleaved PARP) & $(+)$ \\
\hline & & & & SiRNA transfection & $(+)$ \\
\hline
\end{tabular}


Table 2 Genotoxicity of $\mathrm{TiO}_{2} \mathrm{NPs}$ in vivo studies (Continued)

\begin{tabular}{|c|c|c|c|c|c|}
\hline \multirow[t]{3}{*}{ [163] } & \multirow[t]{3}{*}{ Anatase } & \multirow[t]{3}{*}{ BEAS 2B cells } & \multirow[t]{3}{*}{$0,5,50,100 \mu \mathrm{g} / \mathrm{ml}$} & PCR (Caspase 3 and PARP) & $(+)$ \\
\hline & & & & SiRNA knockoutt Bid expression & $(-)$ \\
\hline & & & & Western blot (bcl-2, bax, t-Bid, caspase 9, cytochrome C and p53) & $(+)$ \\
\hline \multirow[t]{2}{*}{ [164] } & \multirow[t]{2}{*}{ P-25 (70-85\% Anatase, 30-15\% rutile) } & \multirow{2}{*}{$\begin{array}{l}\text { Human perip- heral blood } \\
\text { lymphocytes }\end{array}$} & \multirow[t]{2}{*}{$0,20,50,100 \mu \mathrm{g} / \mathrm{ml}$} & Comet assay & $(+)$ \\
\hline & & & & $\begin{array}{l}\text { Western-blot(p53, p63, phospho-p53, Chk1, phospho-Chk1, Chk2, } \\
\text { phospho-Chk2, phospho-FKHR, phospho-FKHRL1) }\end{array}$ & $(+)$ \\
\hline \multirow[t]{2}{*}{ [165] } & \multirow[t]{2}{*}{ P-25 (75\% Anatase, 25\% rutile) } & \multirow[t]{2}{*}{ HaCaT cells } & \multirow[t]{2}{*}{$200 \mu \mathrm{g} / \mathrm{ml}$} & Flow cytometry of apoptosis & $(+)$ \\
\hline & & & & mRNA expression (Keratin 6) & $(+)$ \\
\hline \multirow[t]{2}{*}{ [166] } & \multirow[t]{2}{*}{$\mathrm{TiO}^{2} \mathrm{NPS}$} & \multirow[t]{2}{*}{ Human lymphocytes } & \multirow[t]{2}{*}{$0,2,4,6,8,10 \mathrm{mM}$} & Comet assay & $(+)$ \\
\hline & & & & DNA ladder assay & $(+)$ \\
\hline \multirow[t]{4}{*}{ [167] } & \multirow{4}{*}{$\begin{array}{l}\text { Rutile (>95\%, <5\% SiO }{ }^{2} \text { coating) anatase } \\
(99.7 \%)\end{array}$} & \multirow[t]{4}{*}{ BEAS 2B cells } & \multirow[t]{4}{*}{$1-100 \mu \mathrm{g} / \mathrm{cm}^{2}$} & Comet assay & $(-)$ \\
\hline & & & & CBMN assay & $(-)$ \\
\hline & & & & Comet assay & $(+)$ \\
\hline & & & & CBMN assay & $(+)$ \\
\hline \multirow[t]{2}{*}{ [168] } & \multirow[t]{2}{*}{ PEG-TiO² NPs (P25 80\% anatase, 20\% rutile) } & \multirow{2}{*}{$\begin{array}{l}\text { NCl-H292, HeLa and HepG2 } \\
\text { cells }\end{array}$} & \multirow[t]{2}{*}{$75 \mu \mathrm{g} / \mathrm{ml}$} & RT-PCR (CSF-2) & $(-)$ \\
\hline & & & & RT-PCR (IL6, HMOX-1) & $(+)$ \\
\hline [169] & Anatase, anatase/rutile & Caco-2 cells & $20,80 \mu \mathrm{g} / \mathrm{cm}^{2}$ & Fpg-comet assay & $(+)$ \\
\hline \multirow[t]{2}{*}{ [170] } & \multirow[t]{2}{*}{ Anatase (10/20) } & \multirow[t]{2}{*}{ BEAS-2B cells } & \multirow[t]{2}{*}{$0,5,10 \mu \mathrm{g} / \mathrm{ml}$} & Micronucleus test & $(+)$ \\
\hline & & & & Comet assay & $(+)$ \\
\hline \multirow[t]{4}{*}{ [171] } & \multirow[t]{4}{*}{ P15 } & \multirow{4}{*}{$\begin{array}{l}\mathrm{NIH} 3 \mathrm{~T} 3 \text { cells and human } \\
\text { fibroblast HFW cells }\end{array}$} & $10 \mu \mathrm{g} / \mathrm{ml}$ & Micronucleus assay & $(+)$ \\
\hline & & & & ROS & $(+)$ \\
\hline & & & $50 \mu \mathrm{g} / \mathrm{ml}$ & Colony forming assay & $(+)$ \\
\hline & & & $0-100 \mu \mathrm{g} / \mathrm{ml}$ & Western blot (ERK, MEK) & $(+)$ \\
\hline [172] & Ultrafine $(\leq 20 \mathrm{~nm})$ & SHE cells & $0,0.5,1,5,10 \mu \mathrm{g} / \mathrm{cm}^{2}$ & Micronucleus assay & $(+)$ \\
\hline & & & & Kinetochore staining & $(+)$ \\
\hline & & & & DNA fragmentation & $(+)$ \\
\hline & & & & DNA ladder assay & $(-)$ \\
\hline [173] & P25 anatase & SHE cells & $0,10,25,50 \mu \mathrm{g} / \mathrm{cm}^{2}$ & Comet assay & $(+)$ \\
\hline [174] & $\mathrm{TiO}^{2} \mathrm{NPs}$ & Chinese ham- ster ovary-K1 & $0.5,1 \mu \mathrm{g} / \mathrm{ml}$ & Sister chromatid exchange (SCE) & $(+)$ \\
\hline & & & & Micronucleus assay & $(+)$ \\
\hline [175] & Anatase $(100 \%<25$ nm) & $\begin{array}{l}\text { Chinese ham- ster ovary-K1 } \\
\text { (CHO-K1) cells }\end{array}$ & $0,10,20,40 \mu \mathrm{g} / \mathrm{ml}$ & Comet assay & $(-)$ \\
\hline & & & & Gene mutation assay (Hprt) & $(-)$ \\
\hline
\end{tabular}


Table 2 Genotoxicity of $\mathrm{TiO}_{2}$ NPs in vivo studies (Continued)

\begin{tabular}{|c|c|c|c|c|c|}
\hline \multirow[t]{2}{*}{ [176] } & \multirow{2}{*}{$\begin{array}{l}\text { P25(99.5\% purity, } 73-85 \% \text { anatase/14-17\% } \\
\text { rutile and } 2-13 \% \text { amorphous) }\end{array}$} & \multirow{2}{*}{$\begin{array}{l}\text { Human neonatal foreskin } \\
\text { fibroblast cells }\end{array}$} & \multirow{2}{*}{$\begin{array}{l}0,10,25,50,100,250 \\
500,1000 \mu \mathrm{g} / \mathrm{ml}\end{array}$} & DNA damage & $(+)$ \\
\hline & & & & Immunofluorescent $(\mathrm{\gamma}-\mathrm{H} 2 \mathrm{AX})$ & $(+)$ \\
\hline [177] & Anatase (15 nm, 100\%) & Human dermal fibroblasts & $0,1,3,10 \mu \mathrm{g} / \mathrm{ml}$ & DNA damage (ATM/Chk2) & $(+)$ \\
\hline \multirow[t]{2}{*}{ [179] } & \multirow[t]{2}{*}{ P28 (anatase 90\%, rutile 10\%) } & \multirow[t]{2}{*}{ A549 cells } & \multirow[t]{2}{*}{$0,5,15 \mu \mathrm{g} / \mathrm{ml}$} & ROS & $(-)$ \\
\hline & & & & DNA double strand breaks $(\gamma-\mathrm{H} 2 \mathrm{AX})$ & $(-)$ \\
\hline \multirow[t]{4}{*}{ [180] } & \multirow[t]{4}{*}{ P25 } & \multirow[t]{4}{*}{ A549 cells } & \multirow[t]{4}{*}{$25-500 \mu \mathrm{g} / \mathrm{ml}$} & mRNA expression (Grp78 & $(-)$ \\
\hline & & & & and Hsp70) & \\
\hline & & & & Western blot (Grp78 & $(-)$ \\
\hline & & & & and Hsp70) & \\
\hline [181] & $\mathrm{TiO}^{2} \mathrm{NPS}$ & TA-100 cells & $200 \mu \mathrm{g} / \mathrm{ml}$ & Comet assay & $(-)$ \\
\hline [182] & P25, UV-titan M60 & Rat liver epithelial cells & $0,5,10,20 \mu \mathrm{g} / \mathrm{ml}$ & Micronucleus assay & $(-)$ \\
\hline [183] & Surface treated rutile $\mathrm{TiO}^{2}$ & Caco- 2 cells & $100 \mu \mathrm{g} / \mathrm{ml}$ & Gene expression analysis & $(-)$ \\
\hline
\end{tabular}

(+) positive; (-) negative; ( \pm ) uncertain. 
altered expression of genes associated with brain development, cell death, response to oxidative stress, and mitochondrial activity in the brain during the perinatal period [88]. Even though subcutaneous exposures may not be realistic, this study does show that the fetal nervous system is specifically sensitive to maternal $\mathrm{TiO}_{2} \mathrm{NPs}$ exposure during pregnancy. Moderate alterations in neurobehavior were also noted by Hougaard et al. [90] in mated C57BL/6BomTac mice exposed ( $1 \mathrm{~h} /$ day) through inhalation $\left(42 \mathrm{mg} / \mathrm{m}^{3}\right)$ to surface coated $\mathrm{TiO}_{2} \mathrm{NPs}$ (UVTitan; $97 \mathrm{~nm}$ ) on GD 8-18. Yamashita et al. [190] reported that silica and $\mathrm{TiO}_{2}$ NPs with diameters of 70 and $35 \mathrm{~nm}$, respectively, can cause pregnancy complications when injected intravenously into pregnant mice. The $\mathrm{TiO}_{2} \mathrm{NPs}$ were found in the placenta, fetal liver and fetal brain. Mice treated with $\mathrm{TiO}_{2}$ NPs had smaller uteri and smaller fetuses than untreated controls.

Komatsu et al. [191] investigated the effects of $\mathrm{TiO}_{2}$ NPs on mouse testis Leydig cells in vitro and found $\mathrm{TiO}_{2}$ NPs were more cytotoxic to Leydig cells than diesel exhaust and carbon black NPs. $\mathrm{TiO}_{2} \mathrm{NPs}$ were taken up by Leydig cells, and affected viability, proliferation and gene expression.

In summary, limited in vivo and in vitro studies suggest that $\mathrm{TiO}_{2}$ NPs exposures may exert certain reproductive and developmental toxicities. Further studies are needed to clarify the mechanisms underlying these toxicity results.

\section{Carcinogenicity}

The mechanisms of metal-induced carcinogenesis are not well understood. Both genetic and non-genetic factors elicited by $\mathrm{TiO}_{2} \mathrm{NPs}$ in cells may predispose to carcinogenicity [176].

\section{Experimental studies}

Animal experimental studies show that high concentrations of $\mathrm{TiO}_{2}$ FPs (<2.5 um; $250 \mathrm{mg} / \mathrm{m}^{3} ; 2$ yrs) and $\mathrm{TiO}_{2}$ NPs $\left(<100 \mathrm{~nm} ; 10 \mathrm{mg} / \mathrm{m}^{3} ; 2 \mathrm{yrs}\right)$ can cause respiratory tract cancer in exposed rats $[43,192]$. Chronic lung inhalation studies have shown that $\mathrm{TiO}_{2}$ NPs can cause bronchoalveolar adenomas and cystic keratinizing squamous cell carcinomas at high doses [9] and alveolar/bronchiolar adenoma [193]. Heinrich et al. [194] investigated the carcinogenicity of $\mathrm{TiO}_{2}$ NPs $(15-40 \mathrm{~nm})$ and found $\mathrm{TiO}_{2}$ NPs were tumorigenic in rats at a concentration of approximately $10 \mathrm{mg} / \mathrm{m}^{3}$ for 2 years, followed by a 6 -month holding period. $\mathrm{TiO}_{2} \mathrm{NPs}$ seem to have more carcinogenic potential in the rat than $\mathrm{TiO}_{2}$ FPs on an equal mass dose basis. This difference in carcinogenic potency suggests the need to develop separate risk estimates for $\mathrm{TiO}_{2}$ FPs and NPs exposures, and to develop separate recommendations for occupational exposures to each size range [43].

To assess the health risks of occupational exposure to $\mathrm{TiO}_{2}$ NPs, Kuempel et al. [76] extrapolated rodent data to humans using a lung dosimetry model. The rat-based estimates of the working lifetime airborne concentrations of $\mathrm{TiO}_{2}$ NPs associated with $0.1 \%$ excess risk of lung cancer were approximately 0.07 to $0.3 \mathrm{mg} / \mathrm{m}^{3}$. Using a similar model, Dankovic et al. [43] extrapolated rat threshold estimates to lifetime human occupational exposures and found a range of estimated occupational exposure levels of $0.8-5.8 \mathrm{mg} / \mathrm{m}^{3}$ for $\mathrm{TiO}_{2} \mathrm{FPs}$, and 0.09-0.66 mg/m $/ \mathrm{m}^{3}$ for $\mathrm{TiO}_{2}$ NPs. Such risk analyses formed the basis for development of RELs of 0.3 and 2.4 $\mathrm{mg} / \mathrm{m}^{3}$ for $\mathrm{TiO}_{2}$ NPs and FPs, respectively [50]. Due to the lack of human epidemiological information, these extrapolation models using animal experimental data are still useful in the prediction for risk assessment of occupational exposure to $\mathrm{TiO}_{2} \mathrm{NPs}$.

In an intratracheal instillation study female rats were administered $\mathrm{TiO}_{2}$ hydrophilic or anatase NPs (21-25 $\mathrm{nm}$; 1/week for 30 weeks) of different doses [195]. The incidence of lung tumors (52-69.6\%, adenomas/carcinomas and squamous cell epitheliomas/carcinomas combined) in rats receiving $\mathrm{TiO}_{2}$ hydrophilic or anatase NPs was significantly higher than controls (0\%). Anatase NPs also significantly induced higher incidence of lung tumors (30-63.6\%). The incidence of benign and malignant lung tumors in the $\mathrm{TiO}_{2}$ hydrophilic NPs groups (6.7\%) was not significant. The incidences of cystic keratinizing epitheliomas (11.7\%) and squamous cell carcinomas $(4.8 \%)$ were significantly greater than the control group $(0.5 \%)$ in another inhalation study with female rats treated with $\mathrm{TiO}_{2}$ particles (particle size not stated; $11.3 \mathrm{mg} / \mathrm{m}^{3}$; 24 months, followed by 6 months observation) [196]. Bernard et al. [197] conducted toxicological and carcinogenesis studies of dietary $\mathrm{TiO}_{2}$-coated mica in rats fed diets containing $0,1.0,2.0$, or $5.0 \%$ $\mathrm{TiO}_{2}$-coated mica for up to 130 weeks. They found no evidence that $\mathrm{TiO}_{2}$-coated mica produced either toxicological or carcinogenic effects at dietary concentrations as high as $5.0 \%$.

In regards to skin cancers, a two-stage skin model was used by $\mathrm{Xu}$ et al. [71] to examine the promoting/ carcinogenic effect $\mathrm{TiO}_{2}$ NPs (rutile, $20 \mathrm{~nm}$ ). C-Ha-ras proto-oncogene transgenic (Hras128) rats, which are sensitive to skin carcinogenesis and their wild-type siblings were exposed to UV-B radiation on shaved back skin twice weekly for 10 weeks. The shaved area was then painted with a $100 \mathrm{mg} / \mathrm{ml} \mathrm{TiO}_{2}$ NP suspension twice weekly until sacrifice. The tumor incidence was not different from the UV-B controls. They suggested that $\mathrm{TiO}_{2}$ NPs does not cause skin carcinogenesis, which may be due to its inability to penetrate through the epidermis and reach underlying skin structures. The same conclusion was reached by Sagawa et al. [70] who studied the promoting effect of silicone coated $\mathrm{TiO}_{2}$ NPs (35 nm; 5 times a week for 8 and 40 weeks; 0,10 , or $20 \mathrm{mg}$ ) suspended in 
silicone oil and non-coated $\mathrm{TiO}_{2}$ NPs (20 nm; twice a week for 28 or 40 weeks; 0,50 , or $100 \mathrm{mg}$ ) suspended in Pentalan 408 on a two-stage skin chemical carcinogenesis model. Analysis of skin indicated that silicone coated $\mathrm{TiO}_{2}$ NPs and non-coated $\mathrm{TiO}_{2}$ NPs did not penetrate though either healthy or damaged skin. Newman et al. [65] also suggested that $\mathrm{TiO}_{2}$ NPs are not carcinogenic to the skin because they do not penetrate the intact dermal tissue. However, the authors emphasized that further studies for the safety evaluation of the $\mathrm{TiO}_{2}$ NPs in sunscreens must be done to simulate real-world conditions particularly in sunburned skin and under UV exposure.

Pulmonary studies support the carcinogenicity of $\mathrm{TiO}_{2}$ NPs in intratracheal and inhalation studies. However, exposure modes such as intragastric or dermal exposure do not indicate that $\mathrm{TiO}_{2}$ NPs are carcinogenic.

\section{Epidemiological studies}

Epidemiological studies on workers exposed to $\mathrm{TiO}_{2}$ particles, thus far, have not been able to detect an association between the occupational exposure and an increased risk for lung cancer. Furthermore, most studies were not designed to investigate the relationship between $\mathrm{TiO}_{2}$ particle size and lung cancer risk, which represents an important question for assessing the potential occupational carcinogenicity of $\mathrm{TiO}_{2}$ NPs [32]. The results from the epidemiological studies that have been conducted (no particle size defined) show that there are no significant associations between $\mathrm{TiO}_{2}$ exposure and risk of lung cancer [198,199], elevated standardized mortality ratio (SMR) for cancer [200], and reduction in ventilatory capacity [119]. As a whole, these epidemiological studies imply that occupational exposures to $\mathrm{TiO}_{2}$ FPs (or total dust) are not associated with increasing risk of cancers. Unfortunately, epidemiological studies of adverse health effects induced by $\mathrm{TiO}_{2}$ NPs alone are lacking. The relatively short history in production and use seems to be the main reason for the lack of human epidemiological studies for $\mathrm{TiO}_{2}$ NPs. Furthermore, it is difficult to make reliable hazard assessments of manufactured NPs, because the NPs may form large agglomerates in both in vitro and in vivo studies [51]. Experimental evidence supports that $\mathrm{TiO}_{2}$ NP agglomeration increases when the surface area decreases at a constant $\mathrm{pH}$ and that the isoelectric point for $\mathrm{TiO}_{2}$ depends on the particle size [201]. The interaction of this increased surface area with the biological environment induces oxidative stress [8]. It is worth noting that although $\mathrm{TiO}_{2} \mathrm{NPs}$ are prone to forming agglomerates of $>100 \mathrm{~nm}$ in suspension, these agglomerates are not stable and may dissociate in bodily fluids and tissues. However, the extent of such dissociation has not yet been determined. To evaluate the health effects of $\mathrm{TiO}_{2}$ NPs on workers, further well designed epidemiological studies are needed. The animal studies that have been conducted (those mentioned in this paper) indicate potential risk factors that could be assessed in occupational settings. Examples of potential risk factors are the underlying health of the workers and coexposures.

In summary, available epidemiological studies as well as in vivo animal experimental data concerning the carcinogenic effects of $\mathrm{TiO}_{2}$ particles are outlined above. Epidemiological studies on workers exposed to $\mathrm{TiO}_{2}$ FPs failed to detect an association between the occupational exposure and an increased risk for cancer. Available data from human studies on $\mathrm{TiO}_{2}$ NPs exposures alone are still lacking. Carcinogenicity studies in animals indicate that $\mathrm{TiO}_{2}$ NPs can produce tumors when exposed through inhalation or intratracheal instillation and are more carcinogenic on an equal mass basis than $\mathrm{TiO}_{2}$ FPs. The tumors preferentially include adenomas and squamous cell carcinomas. Based on the studies outlined above, $\mathrm{TiO}_{2}$ NPs were evaluated by World Health Organization (WHO)/IARC as a Group 2B compound [202]. An overview of currently available carcinogenicity data on $\mathrm{TiO}_{2}$ NPs from experimental animals raises serious questions as to their health and environmental safety. Therefore, all commercially available $\mathrm{TiO}_{2}$ NPs should be assessed and their production and application should be managed appropriately. At this stage, risk characterization of $\mathrm{TiO}_{2}$ NPs is hampered by incomplete or lack of data on human exposure and dose- response analysis.

\section{Molecular mechanisms of carcinogenesis}

Many studies have shown that $\mathrm{TiO}_{2}$ FPs and NPs induce cytotoxicity and genotoxicity in various cultured cell lines as well as tumorigenesis in animal models [171]. As stated above, DNA strand breaks, mutations, chromosomal damage and cell transformation have been observed in some in vitro or in vivo studies. However, the exact mechanisms of $\mathrm{TiO}_{2}$ NP-induced carcinogenesis are not clear. Recent evidence indicates that ROS formation, induction of inflammation and alterations in cell signal transduction induced by $\mathrm{TiO}_{2}$ NPs may play an important role in the etiology of their carcinogenesis. Elevated levels of ROS and down regulation of ROS scavengers and antioxidant enzymes are associated with various cancers [203]. ROS consist of a group of partially reduced forms of molecular oxygen, such as hydroxyl radical $(\bullet \mathrm{OH})$, superoxide anion $\left(\mathrm{O}_{2}^{-\bullet}\right)$, singlet oxygen $\left({ }^{1} \mathrm{O}_{2}\right)$, hydrogen peroxide $\left(\mathrm{H}_{2} \mathrm{O}_{2}\right)$, lipid peroxides, and hypochlorous acid ( $\mathrm{HClO})$ [204]. Accumulation of ROS may be accompanied by the production of reactive nitrogen species [205], such as the highly reactive peroxynitrite anion, a strong oxidant formed by the reaction of $\mathrm{O}_{2}^{-*}$ and NO. The cumulative production of ROS through 
either endogenous or exogenous insults is termed oxidative stress. Oxidative stress induces a cellular redox imbalance found in various cancer cells. ROS could induce non-selective DNA damage, which may result in genetic changes in active genes. Oxidative damage to cellular DNA can lead to mutations. The mutations in DNA may be involved in the initiation of various cancers. Therefore, oxidative stress induced by ROS generation may play an important role in the initiation and progression of multistage carcinogenesis of $\mathrm{TiO}_{2}$ NPs. The generation of ROS and induction of inflammation leading to alterations of signaling components due to $\mathrm{TiO}_{2}$ NP exposures are reviewed in this paper.

\section{Generation of ROS}

It has been hypothesized that insoluble particle accumulation in the animal lungs is mechanistically linked to the development of lung tumors [43]. Accumulation of $\mathrm{TiO}_{2}$ NPs in the lung leads to chronic inflammation, which may further lead to the formation of ROS and epithelial proliferation, and eventually lead to mutations and tumor formation. Some of the studies cited previously have reported the involvement of free radicals in DNA damage $[28,157]$, ROS-induced activation of p53mediated DNA damage check point signals [164], increased intracellular ROS leading to increased $G_{2} \mathrm{M}$ cell cycle arrest or delay [156,171], cell-derived oxidants involved in induction of mutagenesis [144], and increased extracellular ROS coupled with $\mathrm{HO}-1$ and NOS mRNA expression and TNF- $\alpha$ release [93]. Others have linked $\mathrm{TiO}_{2}$ NPs (Wistar rats; $1,5,10,25$, and $50 \mu \mathrm{g} / \mathrm{ml} ;<25 \mathrm{~nm}$; $1 \mathrm{~h})$ to ROS generation as a result of mitochondrial dysfunction in lung tissues [206]. Jaeger et al. [207] investigated whether ROS-induced mitochondrial DNA damage is the mode of action by which $\mathrm{TiO}_{2} \mathrm{NPs}(\leq 20 \mathrm{~nm})$ induce cytotoxic and genotoxic effects in human $\mathrm{HaCaT}$ keratinocytes in vitro. They demonstrated the induction of the mitochondrial "common deletion" in $\mathrm{HaCaT}$ cells following exposure to $\mathrm{TiO}_{2}$ NPs. They proposed a ROS-mediated (increased 16.7 fold of control; $4 \mathrm{~h} ; 5$ and $50 \mu \mathrm{g} / \mathrm{ml}$ ) cytotoxic and genotoxic potential for $\mathrm{TiO}_{2}$ NPs. They also showed that $\mathrm{TiO}_{2}$ enters the cell by endocytosis. Another study with $\mathrm{HaCaT}$ cells also showed that $\mathrm{TiO}_{2}$ NPs (anatase, rutile and anatase/ rutile; $4,10,21,25$, and $60 \mathrm{~nm} ; 200 \mu \mathrm{g} / \mathrm{ml}$ ) could induce the generation of ROS and damage the cells under ultraviolet-A (UVA) irradiation [20] . The induced ROS resulted in oxidative stress in the $\mathrm{HaCat}$ cells, reducing SOD and increasing MDA levels. The cell viability was also decreased in a dose dependent manner. Reduction of cell viability and increased $\mathrm{ROS}$ generation by $\mathrm{TiO}_{2}$ NPs under UVA irradiation was also noted by Sanders et al. [208]. Similar effects were seen in a recent study by Yin et al. [209] on HaCat cell cultures. Yoo et al. [210] also stated that sub-100 nm sized $\mathrm{TiO}_{2}$ treatment under UVA irradiation induces apoptotic cell death through ROS-mediated up regulation of the death receptor, Fas, and activation of the pre-apoptotic protein, Bax.

In addition to these, a long term study (intratracheal administration; 2.5, 5, and $10 \mathrm{mg} / \mathrm{kg}$ ) found that $\mathrm{TiO}_{2}$ NPs (5-6 nm) caused oxidative damage in lungs and enhanced expression of $\left(\mathrm{Nrf}_{2}\right), \mathrm{HO}-1$ and glutamatecystine ligase catalytic subunit (GCLC) on days 15 and 75 which began to decrease on day 90 [211]. They suggested that induction of $\mathrm{Nrf}_{2}$ expression was an adaptive intracellular response to $\mathrm{TiO}_{2} \mathrm{NP}$-induced oxidative stress in mouse lung. Another study on PC12 cells found that $\mathrm{TiO}_{2}$ NPs $(1,10,50$, and $100 \mu \mathrm{g} / \mathrm{ml} ; 6,12,24$, and $48 \mathrm{~h}$ ) caused generation of ROS in a dose and timedependent manner, leading to apoptosis [212]. ROSmediated oxidative stress, the activation of p53, Bax, and caspase-3, as well as oxidative DNA damage were found to be involved in the mechanistic pathways of apoptosis induced by $\mathrm{TiO}_{2}$ NPs (anatase; $25 \mathrm{~nm} ; 50,100$, and 200 $\mu \mathrm{g} / \mathrm{ml} ; 24,48$, and $72 \mathrm{~h}$ ) in human embryonic kidney (HEK) 293 cells [213]. These increases followed a dosedependent pattern. Wu et al. [214] also showed the involvement of p53 and JNK activation in G2/M cell cycle arrest and apoptosis induced by anatase $\mathrm{TiO}_{2}$ NPs (20 $\mathrm{nm} ; 25,50,100$, and $200 \mu \mathrm{g} / \mathrm{ml}$ ) in the neuronal cell, PC12. A study on dendritic cells also found that $\mathrm{TiO}_{2}$ NPs enhanced ROS production [215]. Wang et al. [216] found that $\mathrm{TiO}_{2}$ NPs (intragastric exposure; 30 consecutive days) exerted toxicity on the mouse spleen through oxidative stress with significant increases in ROS. This subsequently led to strong LPO and the significant expression of HO-1 via the p38-Nrf-2 signaling pathway.

Uchino et al. [217] showed that the crystal size of $\mathrm{TiO}_{2}$ NPs (anatase; $30 \mathrm{~nm} ; 50 \mu \mathrm{g} / \mathrm{ml}$ ) had large influence on $\cdot \mathrm{OH}$ generation, but the optimum size for the $\cdot \mathrm{OH}$ generation was different between both crystalline forms (anatase and rutile). A significant relationship was observed between cytotoxicity and $\cdot \mathrm{OH}$ generation in CHO cells. $\mathrm{TiO}_{2}$ NPs (rutile; 40-70 nm, minor axis; 200-300 nm, major axis; 40-55 g/100g) were also shown to have the potential to convert benign tumor cells into malignant ones through the generation of ROS in the target cells [218]. However, apart from all of these studies implicating $\mathrm{TiO}_{2}$ NP-generated ROS in cellular and molecular effects, a recent article by Toyooka et al. [219] demonstrated that $\mathrm{TiO}_{2}$ NPs could cause DNA damage without generating ROS. Their study examined the genotoxicity of two different sizes of $\mathrm{TiO}_{2}$ NPs in the A549 cells based on the phosphorylation of $\gamma$-H2AX. Flow cytometric analysis showed that the generation of $\gamma$-H2AX by $\mathrm{TiO}_{2}$ NPs was independent of cell cycle phases, and cells which incorporated larger amounts of $\mathrm{TiO}_{2}$ particles had more significant $\gamma-\mathrm{H} 2 \mathrm{AX}$. 


\section{Induction of inflammation}

Most of the studies previously mentioned in other sections have also reported inflammatory effects due to $\mathrm{TiO}_{2}$ NPs exposure. The details of the molecular events involving inflammation for some of these studies will be discussed here. Cytokines are components of the immune system that are involved in these molecular events, either as agonists or antagonists of inflammation. $\mathrm{TiO}_{2} \mathrm{NPs}$ (anatase; $20 \mathrm{~nm}$; rutile, $80 \mathrm{~nm} ; 7.5-30 \mathrm{mg} / \mathrm{kg}$ ) signaled the interleukin 1 (IL-1 $\alpha$ ) family of cytokines in a mouse lung model [142]. The signaling of IL-1R by $\mathrm{TiO}_{2}$ NPs is similar to that of asbestos. Others showed that IL- $1 \beta$ production was depended on active cathepsin $B$ and ROS production independent of the characteristics of $\mathrm{TiO}_{2}$ [159]. Another study showed increased expression of IL-1 $\beta$, IL-2, IL-4, IL-6, IL-10, and IL-18, in nephritic inflammation caused by $\mathrm{TiO}_{2}$ NPs intragastrically administered to mice $(5-6 \mathrm{~nm} ; 2.5,5$, and $10 \mathrm{mg} / \mathrm{kg}$; everyday for 90 days) [146]. In addition, $\mathrm{TiO}_{2}$ NPs activated NF- $k B$, leading to increased expression of TNF- $\alpha$, MMIF, cross-reaction protein, TGF- $\beta$, interferon- $\gamma$, and CYP1A1, and decreased Hsp70 expression. Moon et al. [220] showed that the levels of pro-inflammatory mediators, such as IL- $1 \beta$, TNF- $\alpha$, and macrophage inflammatory protein (MIP)-2, in BALF and mRNA expression of TNF- $\alpha$ and IL- $1 \beta$ in lung tissue were elevated post-exposure in mice (intraperitoneal; $40 \mathrm{mg} / \mathrm{kg} \mathrm{BW}$ ). $\mathrm{TiO}_{2}$ NP exposure increased neutrophil influx, protein levels in BALF, and ROS activity of BAL cells $4 \mathrm{~h}$ after exposure. In addition, $\mathrm{TiO}_{2} \mathrm{NP}$ exposure resulted in significant activation of inflammatory signaling molecules, such as c-Src and p38 mitogen-activated protein kinase (MAPK), in lung tissue and alveolar macrophages. Activation of the NF- $\kappa B$ pathway in pulmonary tissue was also noted. Kan et al. [143] showed that $\mathrm{TiO}_{2}$ NPs increased phosphorylation of p38 and troponin 1 in cardiac muscle. It can be seen here that the induction of inflammation by $\mathrm{TiO}_{2} \mathrm{NPs}$ involves a host of other molecular components and events including the signaling of cytokines. Additional evidence for this is shown by the following references $[145,154,160,162,180]$.

Recent research indicates that $\mathrm{TiO}_{2}$ particle-induced alterations in signal transduction may also play an important role in the etiology of cancer. Goncalves et al. [221] investigated the in vitro effects of $\mathrm{TiO}_{2} \mathrm{NPs}$ on human neutrophils. Kinetic experiments revealed no cell necrosis after a $24 \mathrm{~h}$ treatment with $\mathrm{TiO}_{2}$ NPs $(0-100$ $\mu \mathrm{g} / \mathrm{ml}$ ). However, $\mathrm{TiO}_{2}$ NPs markedly and rapidly induced tyrosine phosphorylation events, including phosphorylation of two key enzymes, p38 MAPK and extracellular signal-regulated kinases-1/2 (Erk-1/2). Supernatants from induced neutrophils were collected after $24 \mathrm{~h}$ and tested for the presence of 36 different analytes (cytokines, chemokines) using an antibody array assay. $\mathrm{TiO}_{2}$ NP treatment increased production of $13(36 \%)$ analytes, including IL-8, which exhibited the greatest increase (approximately 16 fold increase compared to control). These results indicate $\mathrm{TiO}_{2} \mathrm{NPs}$ exert important neutrophil agonistic properties in vitro which represents one of the characteristics of carcinogens. Chen et al. [118] pointed out that a mixture of anatase and rutile $\mathrm{TiO}_{2} \mathrm{NPs}(<100 \mathrm{~nm}$, anatase/rutile $99.5 \%$ trace metal basis; $0-0.75 \mathrm{mg} / \mathrm{ml})$ induced histamine secretion in mast cells $\left(\mathrm{RBL}-{ }_{2} \mathrm{H}_{3}\right.$ cells). Mast cell exposure to $\mathrm{TiO}_{2}$ NPs activated membrane L-type $\mathrm{Ca}^{2+}$ channels, induce ROS production and stimulate PLC activity. Influx of extracellular $\mathrm{Ca}^{2+}$ raises $\left[\mathrm{Ca}^{2+}\right]_{\mathrm{i}}$, and when coupled with the $\mathrm{IP}_{3}-\mathrm{IP}_{3}$ receptor pathway can trigger the release of ER resident $\mathrm{Ca}^{2+}$ and subsequent histamine secretion. They stated that $\mathrm{TiO}_{2}$ NPs directly trigger inflammatory mediators, thus bypassing traditional immuno-stimulation by allergens. These results suggest that mast cell degranulation of histamine may be significantly augmented and intensified in $\mathrm{TiO}_{2} \mathrm{NP}$ exposed tissues with or without IgE antibody-based sensitization.

In conclusion, research evidence seems to be sufficient to conclude that both $\mathrm{TiO}_{2}$ FPs and NPs generate ROS as demonstrated by both in vivo and in vitro studies. ROS-induced signaling and activation of the IL family of cytokines, Bax, caspases 3 and 9, NF- $\mathrm{kB}$, and p53, as well as phosphorylation of p38 and $\mathrm{G}_{2} \mathrm{M}$ phase cell cycle arrest seem to be common findings. In regards to induction of inflammation leading to the production of ROS, inflammatory cytokines seem to play an influencing role. Furthermore, experimental data suggest that ROS generation and oxidative stress may be important in $\mathrm{TiO}_{2} \mathrm{NP}-$ induced genotoxicity and carcinogenicity. The exact mechanisms of $\mathrm{TiO}_{2} \mathrm{NP}$ induced carcinogenesis are not clear. Limited data show that ROS, oxidative stress, as well as, cell signaling alterations of carcinogenic genes may all play significant roles in the carcinogenicity of $\mathrm{TiO}_{2}$ NPs at relatively high doses. Further studies are needed employing lower, occupationally relevant doses, which avoid the confounding influence of possible overload.

\section{Summary}

Conventionally, $\mathrm{TiO}_{2}$ FPs have been considered as a low toxicity material. $\mathrm{TiO}_{2}$ NPs possess different physicochemical properties compared to $\mathrm{TiO}_{2} \mathrm{FPs}$, which would be expected to alter their biological properties. A full risk assessment for various routes of exposure to $\mathrm{TiO}_{2}$ NPs requires further data. Apart from the NIOSH recommended REL, to date, no occupational or environmental exposure limits for $\mathrm{TiO}_{2} \mathrm{NPs}$ have been set by any other regulatory agency. Current understanding on their toxicity largely depends on a limited number of experimental animal or cell culture studies, where 
extrapolation to human exposures is required. Epidemiological studies thus far have not been able to detect an association between the occupational exposure to $\mathrm{TiO}_{2}$ particles and an increased risk for cancer. The physicochemical properties of $\mathrm{TiO}_{2}$ NPs may strongly influence their bioavailability and toxicity. Majority of data imply that $\mathrm{TiO}_{2}$ anatase NPs are cytotoxic or genotoxic. However, this conclusion was based on studies using $\mathrm{TiO}_{2}$ anatase NPs only. Under conditions of occupational exposure, inhalation of $\mathrm{TiO}_{2} \mathrm{NPs}$ is normally the principal route for entry into the human body. Pulmonary inflammatory responses and lung cancers are the most important adverse effect observed in experimental animals due to $\mathrm{TiO}_{2} \mathrm{NP}$ exposures. When only using realistic doses are considered, as in the case of some inhalation studies, inflammatory responses are still a prominent effect seen. $\mathrm{TiO}_{2}$ NPs can be absorbed through the lung or GIT into systematic circulation and then distributed in different organs such as liver, kidneys, spleen, or even brain causing localized effects. However, the rate of such translocation is currently uncertain. Some evidence has shown that $\mathrm{TiO}_{2}$ NPs cannot penetrate the intact skin into the human body. $\mathrm{TiO}_{2}$ NPs may have the potential to penetrate the blood-brain, blood-testis and blood-placenta barriers. However, the rate of translocation appears low and evidence is lacking which link systemic responses to translocation of particles to systemic sites. Many studies have been conducted in vitro and in vivo to investigate the genotoxicity of $\mathrm{TiO}_{2}$ NPs but the results are conflicting and doses employed were high. Certain reproductive and developmental toxicities in experimental animals or cell cultures have been observed in a few in vivo and in vitro studies. Whether human exposure to $\mathrm{TiO}_{2}$ NPs causes reproductive and developmental toxicities is unclear. Animal studies imply that accumulation of $\mathrm{TiO}_{2}$ NPs in organs or tissues may take place after continuous exposure. Responses to accumulation of $\mathrm{TiO}_{2}$ NPs in systemic organs need to be evaluated in further studies. In addition, $\mathrm{TiO}_{2} \mathrm{NP}$-induced generation of ROS and alterations in cell signal transduction pathways may play an important role in the etiology of carcinogenesis of $\mathrm{TiO}_{2}$ NPs at relatively high doses. However, these studies should be repeated at doses relevant to normal occupational or environmental exposure conditions where particle overload is not an issue. Despite this, the results currently available imply that $\mathrm{TiO}_{2}$ NPs exhibit greater toxicity than $\mathrm{TiO}_{2}$ FPs. These data should not be ignored, and development of prevention strategies to protect worker's health appears to be a prudent course of action.

In summary, although $\mathrm{TiO}_{2}$ NPs have been studied extensively in recent years, there is still much remaining to be elucidated concerning their possible health effects to support risk assessment and management.
First, to assure worker and consumer safety, it is urgently important to conduct exposure hazard assessment, which would allow the development of a framework enabling risk management for all commercial $\mathrm{TiO}_{2}$ NPs. This also includes bio-safety evaluation of $\mathrm{TiO}_{2}$ nanoparticulate carriers for drug delivery application.

Second, all future studies on $\mathrm{TiO}_{2}$ NPs should characterize the physicochemical properties of the NPs, such as size distribution, crystalline structure, surface area, surface coating, etc., as delivered to the biological system. This will allow for better comparison of data from different studies and assist in determination of appropriate dosimetry.

Third, long-term animal studies comparing the toxicity and carcinogenicity of $\mathrm{TiO}_{2}$ FPs and NPs are especially needed. The focus of these studies must be aimed at both occupational and consumer relevant doses and routes of exposure.

Fourth, detailed toxicokinetics studies that include absorption, distribution, metabolism, accumulation, and excretion of $\mathrm{TiO}_{2}$ NPs through different exposure routes into the human body are indispensable. In addition, future studies should focus on evaluating systemic responses distinct from the organ of exposure and biomarkers reflecting $\mathrm{TiO}_{2}$ NP exposure and toxic effects.

Finally, the molecular mechanisms by which TiO2 NPs may cause cancer are unclear. Limited data show that ROS generation and signal alterations of certain cancerrelated genes may be involved in the carcinogenicity of $\mathrm{TiO}_{2}$ NPs. Therefore, further investigation is needed to elucidate the molecular mechanisms of carcinogenicity for $\mathrm{TiO}_{2}$ NPs.

\section{Abbreviations}

(3-D-HB): 3-D-hydroxybutyrate; (DOPAC): 3,4-dihydroxyphenylacetic acid; (5HT): 5-hydroxytryptamine; (5-HIAA): 5-hydroxyindole acetic acid; (AOO): Acetone-Olive Oil; (AHR): Airway hyper-reactivity; (ALT): Alanine aminotransferase; (ACGIH): American Conference of Governmental Industrial Hygienists; (AST): Aspartate aminotransferase; (BER): Base excision repair; (BBB): Blood brain-barriers; (BUN): Blood urea nitrogen; (BW): Body weight; (BALF): Bronchoalveolar lavage fluid; (BEAS-2B): Bronchial Epithelial; (CHO$\mathrm{K} 1$ ): Chinese hamster ovary-K1; (Hras128): C-Ha-ras proto-oncogene transgenic; (CK): Creatine kinase; (CBMN): Cytokinesis block micronucleus; (DA): Dopamine; (ELISA): Enzyme-linked immunosorbent assay; (ESTR): Expanded simple tandem repeat; (FcyRll): Fcy receptor Il; (FP): Fine particle; (FPs): Fine particles; (FDA): Food and Drug Administration; (GIT): Gastrointestinal tract; (GD): Gestation days; (GCLC): Glutamate-cystine Ligase Catalytic Subunit; (GST): Glutathione S-transferase; (Hsp70): Heat shock protein 70; (HO-1): Hemeoxygenase-1; (HDL-C): High density lipoprotein cholesterol; (HVA): Homovanillic; (HEK): Human embryonic kidney; $(1 \mathrm{H}$ NMR): Hydrogen-1 nuclear magnetic resonance spectroscopy; ( $\mathrm{HClO})$ : Hypochlorous acid; $\left(\mathrm{H}_{2} \mathrm{O}_{2}\right)$ : Hydrogen peroxide; $(\cdot \mathrm{OH})$ : Hydroxy radical; (HPRT): Hypoxanthine phosphoribosyltransferase; (IKK-a IKK- $\beta$ ): IKB kinases; (IL): Interleukin; (IARC): International Agency for Research on Cancer; (LDH): Lactate dehydrogenase; (LPO): Lipid peroxidation; (LEV): Local exhaust ventilation; (LDL-C): Low density lipoprotein cholesterin; (MIP): Macrophage inflammatory protein; (MMIF): Macrophage migration inhibitory factor; (MDA): Malodialdehyde; $\left(L D_{50}\right)$ : Median lethal dose; $\left(L C_{50}\right)$ : Median lethal concentration; (MN): Micronucleus; (MMP): Mitochondrial membrane potential; (MAPK): Mitogen-activated Protein Kinase; (NAC): N-acetylcysteine; (NP): Nanoparticle; (NPs): Nanoparticles; (NIOSH): National Institute for 
Occupational Safety and Health; (NEDO): New Energy and Industrial Technology Development Organization; (NIK): NF-KB-inducible kinase; (NO): Nitric oxide; (NOS): Nitric oxide synthase; (NOAEL): No Observed Adverse Effect Level; (NE): Norepinephrine; (NF-kB): Nuclear factor kappa-light -chain-enhancer of activated B cells; (NER): Nucleotide excision repair; (OSHA): Occupational Safety \& Health Administration; (OTM): Olive tail moment; (OECD): Organization for Economic Co-operation and Development; (OVA): Ovalbumin; (PM): Particulate matter; (PEL): Permissible exposure limit; (PAG): Phenylacetylglycine; (PDT): Photodynamic therapy; (PCE): Polychromatic erythrocyte; (PEG): Polyethylene glycol; (ROS): Reactive oxygen species; (REL): Recommended exposure limit; (RDI): Relative deposition index; (RP-HPLC): Reversed-phase high performance liquid chromatography; (RT-PCR): Real-time quantitative PCR; (SEM): Scanning electron microscopy; (Saa1): Serum amyloid A-1; (Saa3): Serum amyloid A-3; (SGOT): Serum glutamic oxaloacetic transaminase; (SGOT): Serum glutamic pyruvic transaminase; $\left({ }^{1} \mathrm{O}_{2}\right)$ : Singlet oxygen; $\left(\mathrm{SiO}_{2}\right)$ : Silicon dioxide; (SCE): Sister chromatid exchange; (SMR): Standardized mortality ratio; (SC): Stratum corneum; $\left(\mathrm{O}_{2}^{--}\right)$: Superoxide anion; (SOD): Superoxide dismutase; (TEM-EDX): TEM-coupled Energy Dispersive X-ray; (TOF-SIMS: Time of Flight Secondary lon Mass Spectrometry; (TWA): Time weighted average; (TIMP2): Tissue inhibitors of metalloproteinases 2; $(\mathrm{Ti})$ : Titanium; $\left(\mathrm{TiO}_{2}\right)$ : Titanium dioxide; (TLV): Threshold limit value; (TLR2): Toll-like receptor-2; (TDI): Toluene diisocyanate; (TC): Total cholesterol; (TGF- $\beta$ ): Transforming growth factor- $\beta$; (TEM): Transmission electron microscopy; (TG): Triglyceride;

(TMAO): Trimethylamine-N-oxide; (TNF-a): Tumor necrosis factor-a;

(UVA): Ultraviolet-A; (UVB): Ultraviolet- $\mathrm{B}_{;}\left(\mathrm{V}_{2} \mathrm{O}_{5}\right)$ : Vanadium pentoxide; (WHO): World Health Organization.

\section{Competing interests}

The authors declare that they have no competing interests.

\section{Authors' contributions}

HS and RM were involved in writing the manuscript, JZ and VC helped to organize and proof read the final manuscript. All authors read and approved the final manuscript.

\section{Authors' information}

Miss Hongbo Shi and Ruth Magaye are graduate students at Ningbo University, China. Their current research focus is on nanotoxicology of nanomaterials. As authors or co-authors they have collectively published 7 scientific manuscripts.

Vincent Castranova, Ph.D., is the Chief of the Pathology and Physiology Research Branch in the Health Effects Laboratory Division of the National Institute for Occupational Safety and Health, Morgantown, West Virginia. Dr. Castranova's research interests have been concentrated in pulmonary toxicology and occupational lung disease. He has been coordinator of the Nanotoxicology Program in NIOSH since its inception in 2005. He has been a co-editor of four books and has co-authored over 540 manuscripts and book chapters.

Dr. Jinshun Zhao works is a professor and director of the Public Health Department of Medical School of Ningbo University, Ningbo, Zhejiang, China. Dr. Jinshun Zhao's research interests have been concentrated in occupational and environmental disease, toxicology and molecular mechanisms of chemical and metal-induced carcinogenesis. His current research is focused on the toxicology of nanomaterials. As an author or a coauthor, he has published over 100 scientific manuscripts.

\section{Acknowledgements}

The excellent assistance of Mrs. Linda Bowman, Prof. Gunter Oberdorster, Mrs Baobo Zou, Mr. Kui Liu and Miss Xia Yue in the preparation of this article is greatly appreciated. This work was partly supported by the National Nature Science Foundation of China (Grant No.81273111), the Foundations of Innovative Research Team of Educational Commission of Zhejiang Province (T200907), the Nature Science Foundation of Ningbo city (Grant No.2012A610185), the Ningbo Scientific Project (SZX11073 and 2012C5019), the Scientific Innovation Team Project of Ningbo (no. 2011B82014), Innovative Research Team of Ningbo (2009B21002) and K.C. Wong Magna Fund in Ningbo University.

\section{Disclaimer}

The findings and conclusions in this report are those of the authors and do not necessarily represent the views of the National Institute for Occupational Safety and Health.

\section{Author details}

${ }^{1}$ Public Health Department of Medical School, Zhejiang Provincial Key Laboratory of Pathological and Physiological Technology, Ningbo University, Ningbo, Zhejiang Province 315211, P. R. China. ${ }^{2}$ Pathology and Physiology Research Branch, Health Effects Laboratory Division, National Institute for Occupational Safety and Health, Morgantown, WV 26505, USA.

Received: 20 November 2012 Accepted: 2 April 2013

Published: 15 April 2013

\section{References}

1. Kisin ER, Murray AR, Keane MJ, Shi XC, Schwegler-Berry D, Gorelik O, Arepalli S, Castranova V, Wallace WE, Kagan VE, Shvedova AA: Single-walled carbon nanotubes: geno- and cytotoxic effects in lung fibroblast V79 cells. J Toxicol Environ Health A 2007, 70:2071-2079.

2. Robertson TA, Sanchez WY, Roberts MS: Are commercially available nanoparticles safe when applied to the skin? I Biomed Nanotechnol 2010, 6:452-468.

3. EU - European Commission Recommendation on the definition of nanomaterial. http://osha.europa.eu/en/news/eu-european-commissionrecommendation-on-the-definition-of-nanomaterial.

4. Riu J, Maroto A, Rius FX: Nanosensors in environmental analysis. Talanta 2006, 69(2):288-301.

5. Ruth Magaye JZ, Linda B, Min D: Genotoxicity and carcinogenicity of cobalt-, nickel- and copper-based nanoparticles (Review). Exp Ther Med 2012, 4:551-561.

6. American Conference of Governmental Industrial Hygienists (ACGIH): Threshold limit values and biological exposure indices for 1992-1993. Cincinnati: Ohio: American Conference of Governmental industrial hygienists; 1992

7. Participants IRSIW: The relevance of the rat lung response to particle overload for human risk assessment: a workshop consensus report. Inhal Toxicol 2000, 12:1-17.

8. Zhao J, Bowman L, Zhang X, Vallyathan V, Young SH, Castranova V, Ding M: Titanium dioxide (TiO2) nanoparticles induce JB6 cell apoptosis through activation of the caspase-8/Bid and mitochondrial pathways. J Toxicol Environ Health A 2009, 72:1141-1149.

9. Lee KP, Trochimowicz HJ, Reinhardt CF: Pulmonary response of rats exposed to titanium dioxide (TiO2) by inhalation for two years. Toxicol Appl Pharmacol 1985, 79:179-192

10. IARC: Cobalt in Hard Metals and Cobalt Sulfate, Gallium Arsenide, Indium Phosphide and Vanadium Pentoxide. IARC Sci Publ 2006, 86.

11. Maynard AD, Kuempel ED: Airborne nanostructured particles and occupational health. J Nanopart Res 2005, 6:587-614.

12. Tsuji JS, Maynard AD, Howard PC, James JT, Lam CW, Warheit DB, Santamaria AB: Research strategies for safety evaluation of nanomaterials, part IV: risk assessment of nanoparticles. Toxicol Sci 2006, 89:42-50.

13. Fabian E, Landsiedel R, Ma-Hock L, Wiench K, Wohlleben W, van Ravenzwaay B: Tissue distribution and toxicity of intravenously administered titanium dioxide nanoparticles in rats. Arch Toxicol 2008, 82:151-157.

14. Oberdorster G: Pulmonary effects of inhaled ultrafine particles. Int Arch Occup Environ Health 2001, 74:1-8.

15. Oberdorster G, Ferin J, Lehnert BE: Correlation between particle size, in vivo particle persistence, and lung injury. Environ Health Perspect 1994 102(Suppl 5):173-179.

16. Sager TM, Kommineni C, Castranova V: Pulmonary response to intratracheal instillation of ultrafine versus fine titanium dioxide: role of particle surface area. Part Fibre Toxicol 2008, 5:17.

17. Long TC, Tajuba J, Sama P, Saleh N, Swartz C, Parker J, Hester S, Lowry GV, Veronesi B: Nanosize titanium dioxide stimulates reactive oxygen species in brain microglia and damages neurons in vitro. Environ Health Perspect 2007, 115:1631-1637.

18. Warheit DB, Webb TR, Reed KL, Frerichs S, Sayes CM: Pulmonary toxicity study in rats with three forms of ultrafine-TiO2 particles: differentia responses related to surface properties. Toxicology 2007, 230:90-104. 
19. Sayes CM, Wahi R, Kurian PA, Liu Y, West $J$, Ausman KD, Warheit DB, Colvin VL: Correlating nanoscale titania structure with toxicity: a cytotoxicity and inflammatory response study with human dermal fibroblasts and human lung epithelial cells. Toxicol Sci 2006, 92:174-185.

20. Xue C, Wu J, Lan F, Liu W, Yang X, Zeng F, Xu H: Nano titanium dioxide induces the generation of ROS and potential damage in $\mathrm{HaCaT}$ cells under UVA irradiation. J Nanosci Nanotechnol 2010, 10:8500-8507.

21. Petkovic J, Zegura B, Stevanovic M, Drnovsek N, Uskokovic D, Novak S, Filipic M: DNA damage and alterations in expression of DNA damage responsive genes induced by $\mathrm{TiO} 2$ nanoparticles in human hepatoma HepG2 cells. Nanotoxicology 2011, 5:341-353.

22. Wang C, Li Y: Interaction and nanotoxic effect of TiO(2) nanoparticle on fibrinogen by multi-spectroscopic method. Sci Total Environ 2012, 429:156-160.

23. Andersson POLC, Ekstrand-Hammarstrom B, Akfur C, Ahlinder L, Bucht A, Osterlund L: Polymorph- and Size-Dependent Uptake and Toxicity of TiO2 Nanoparticles in Living Lung Epithelial Cells. Small 2011, 7:514-523.

24. Tedja R, Lim M, Amal R, Marquis C: Effects of serum adsorption on cellular uptake profile and consequent impact of titanium dioxide nanoparticles on human lung cell lines. ACS Nano 2012, 6:4083-4093.

25. Saber AT, Jensen KA, Jacobsen NR, Birkedal R, Mikkelsen L, Moller P, Loft S, Wallin $\mathrm{H}$, Vogel $\mathrm{U}$ : Inflammatory and genotoxic effects of nanoparticles designed for inclusion in paints and lacquers. Nanotoxicology 2012, 6:453-471

26. Ortlieb M: White Giant or White Dwarf?: Particle Size Distribution Measurements of TiO2. GIT Lab J Eur 2010, 14:42-43.

27. Baan R, Straif K, Grosse Y, Secretan B, El Ghissassi F, Cogliano V: Carcinogenicity of carbon black, titanium dioxide, and talc. Lancet Onco 2006, 7:295-296.

28. Shukla RK, Sharma V, Pandey AK, Singh S, Sultana S, Dhawan A: ROS mediated genotoxicity induced by titanium dioxide nanoparticles in human epidermal cells. Toxicol In Vitro 2011, 25:231-241.

29. Kaida T, Kobayashi K, Adachi M, Suzuki F: Optical characteristics of titanium oxide interference film and the film laminated with oxides and their applications for cosmetics. J Cosmet Sci 2004, 55:219-220.

30. Wang JJ, Sanderson BJ, Wang H: Cyto- and genotoxicity of ultrafine TiO2 particles in cultured human lymphoblastoid cells. Mutat Res 2007, 628:99-106.

31. Wolf R, Matz H, Orion E, Lipozencic J: Sunscreens-the ultimate cosmetic. Acta Dermatovenerol Croat 2003, 11:158-162.

32. Trouiller B, Reliene R, Westbrook A, Solaimani P, Schiestl RH: Titanium dioxide nanoparticles induce DNA damage and genetic instability in vivo in mice. Cancer Res 2009, 69:8784-8789.

33. Jacobs JJ, Skipor AK, Black J, Urban R, Galante JO: Release and excretion of metal in patients who have a total hip-replacement component made of titanium-base alloy. J Bone Joint Surg Am 1991, 73:1475-1486.

34. Sul YT: Electrochemical growth behavior, surface properties, and enhanced in vivo bone response of $\mathrm{TiO}_{2}$ nanotubes on microstructured surfaces of blasted, screw-shaped titanium implants. Int I Nanomedicine 2010, 5:87-100.

35. Patri A, Umbreit T, Zheng J, Nagashima K, Goering P, Francke-Carroll S, Gordon E, Weaver J, Miller T, Sadrieh N, et al: Energy dispersive X-ray analysis of titanium dioxide nanoparticle distribution after intravenous and subcutaneous injection in mice. J App/ Toxicol 2009, 29:662-672.

36. Ni M, Leung MKH, Leung DYC, Sumathy K: A review and recent developments in photocatalytic water-splitting using $\mathrm{TiO} 2$ for hydrogen production. Renewable and Sustainable Energy Reviews 2007, 11:401-425.

37. Yuan Y, Ding J, Xu J, Deng J, Guo J: TiO2 nanoparticles co-doped with silver and nitrogen for antibacterial application. J Nanosci Nanotechnol 2010, 10:4868-4874.

38. Montazer M, Seifollahzadeh S: Enhanced self-cleaning, antibacterial and UV protection properties of nano $\mathrm{TiO} 2$ treated textile through enzymatic pretreatment. Photochem Photobiol 2011, 87:877-883.

39. Szacilowski K, Macyk W, Drzewiecka-Matuszek A, Brindell M, Stochel G: Bioinorganic photochemistry: frontiers and mechanisms. Chem Rev 2005 105:2647-2694.

40. Wiesenthal A, Hunter L, Wang S, Wickliffe J, Wilkerson M: Nanoparticles: small and mighty. Int J Dermatol 2011, 50:247-254.

41. Montazer M, Behzadnia A, Pakdel E, Rahimi MK, Moghadam MB: Photo induced silver on nano titanium dioxide as an enhanced antimicrobial agent for wool. J Photochem Photobiol B 2011, 103:207-214.
42. Schkroeder HA, Balassa JJ, Tipton $\mathrm{H}$ : Abnormal trace metals in man: titanium. J Chronic Dis 1963, 16:55-69.

43. Dankovic D, Kuempel E, Wheeler M: An approach to risk assessment for TiO2. Inhal Toxicol 2007, 19(Suppl 1):205-212.

44. Weir A, Westerhoff P, Fabricius L, Hristovski K, von Goetz N: Titanium dioxide nanoparticles in food and personal care products. Environ Sci Technol 2012, 46:2242-2250.

45. Zhao J, Castranova V: Toxicology of nanomaterials used in nanomedicine. J Toxicol Environ Health B Crit Rev 2011, 14:593-632.

46. Saber AT, Jacobsen NR, Mortensen A, Szarek J, Jackson P, Madsen AM, Jensen KA, Koponen IK, Brunborg G, Gutzkow KB, et al: Nanotitanium dioxide toxicity in mouse lung is reduced in sanding dust from paint. Part Fibre Toxicol 2012, 9:4

47. FDA: Listing of color additives exempt from certification. In Code of Federal Regulations Title 21-Food and Drugs. 21 CFR 73.2575. Washington, DC: US Government Printing Office; 2002.

48. ACGIH: Titanium dioxide. In Documentation of the threshold limit values for chemical substances. 7th edition. Cincinnati, $\mathrm{OH}$ : American Conference of Governmental Industrial Hygienists; 2001.

49. Kitchin KT, Prasad RY, Wallace K: Oxidative stress studies of $\operatorname{six} \mathrm{TiO}(2)$ and two $\mathrm{CeO}(2)$ nanomaterials: Immuno-spin trapping results with DNA. Nanotoxicology 2010, 5:546-556.

50. NIOSH: Occupational Exposure to Titanium Dioxide. In Current Intelligence Bulletin 63. Cincinnati: National Institute for Occupational Safety and Health; 2011.

51. Morimoto Y, Kobayashi N, Shinohara N, Myojo T, Tanaka I, Nakanishi J: Hazard Assessments of Manufactured Nanomaterials. J Occup Health 2010, 52:325-324

52. Curwin B, Bertke S: Exposure characterization of metal oxide nanoparticles in the workplace. J Occup Environ Hyg 2011, 8:580-587.

53. Lee JH, Kwon M, Ji JH, Kang CS, Ahn KH, Han JH, Yu IJ: Exposure assessment of workplaces manufacturing nanosized TiO2 and silver. Inhal Toxicol 2011, 23:226-236.

54. Methner MM: Effectiveness of a custom-fitted flange and local exhaust ventilation (LEV) system in controlling the release of nanoscale metal oxide particulates during reactor cleanout operations. Int J Occup Environ Health 2010, 16:475-487.

55. Hagens WI, Oomen AG, de Jong WH, Cassee FR, Sips AJ: What do we (need to) know about the kinetic properties of nanoparticles in the body? Regul Toxicol Pharmacol 2007, 49:217-229.

56. Lomer MC, Thompson RP, Powell JJ: Fine and ultrafine particles of the diet: influence on the mucosal immune response and association with Crohn's disease. Proc Nutr Soc 2002, 61:123-130.

57. Hillyer JF, Albrecht RM: Gastrointestinal persorption and tissue distribution of differently sized colloidal gold nanoparticles. J Pharm Sci 2001, 90:1927-1936.

58. Jania P, McCarthya D, Florence AT: Titanium dioxide (rutile) particle uptake from the rat GI tract and translocation to systemic organs after oral administration. Int J Pharm 1994, 105:157-168.

59. Wang J, Zhou G, Chen C, Yu H, Wang T, Ma Y, Jia G, Gao Y, Li B, Sun J, et al: Acute toxicity and biodistribution of different sized titanium dioxide particles in mice after oral administration. Toxicol Lett 2007, 168:176-185

60. Senzui M, Tamura T, Miura K, Ikarashi Y, Watanabe Y, Fujii M: Study on penetration of titanium dioxide $(\mathrm{TiO}(2))$ nanoparticles into intact and damaged skin in vitro. J Toxicol Sci 2010, 35:107-113.

61. Schulz J, Hohenberg H, Pflucker F, Gartner E, Will T, Pfeiffer S, Wepf R, Wendel V, Gers-Barlag H, Wittern KP: Distribution of sunscreens on skin. Adv Drug Deliv Rev 2002, 54(Suppl 1):S157-163.

62. Pflucker F, Wendel V, Hohenberg H, Gartner E, Will T, Pfeiffer S, Wepf R, Gers-Barlag $\mathrm{H}$ : The human stratum corneum layer: an effective barrier against dermal uptake of different forms of topically applied micronised titanium dioxide. Skin Pharmacol App/ Skin Physiol 2001, 14(Suppl 1):92-97.

63. Gamer $A O$, Leibold $E$, van Ravenzwaay $B$ : The in vitro absorption of microfine zinc oxide and titanium dioxide through porcine skin. Toxicol In Vitro 2006, 20:301-307.

64. Sadrieh N, Wokovich AM, Gopee NV, Zheng J, Haines D, Parmiter D, Siitonen $\mathrm{PH}$, Cozart CR, Patri AK, McNeil SE, et al: Lack of significant dermal penetration of titanium dioxide from sunscreen formulations containing nano- and submicron-size TiO2 particles. Toxicol Sci 2010, 115:156-166.

65. Newman MD, Stotland M, Ellis Jl: The safety of nanosized particles in titanium dioxide- and zinc oxide-based sunscreens. J Am Acad Dermatol 2009, 61:685-692. 
66. Lademann J, Weigmann H, Rickmeyer C, Barthelmes $H$, Schaefer $H$, Mueller $\mathrm{G}$, Sterry W: Penetration of titanium dioxide microparticles in a sunscreen formulation into the horny layer and the follicular orifice. Skin Pharmacol Appl Skin Physiol 1999, 12:247-256.

67. Escobar-Chavez JJ, Merino-Sanjuan V, Lopez-Cervantes M, Urban-Morlan Z, Pinon-Segundo E, Quintanar-Guerrero D, Ganem-Quintanar A: The tapestripping technique as a method for drug quantification in skin. J Pharm Pharm Sci 2008, 11:104-130.

68. Tan MH, Commens CA, Burnett L, Snitch PJ: A pilot study on the percutaneous absorption of microfine titanium dioxide from sunscreens. Australas J Dermatol 1996, 37:185-187.

69. Bennat C, Muller-Goymann CC: Skin penetration and stabilization of formulations containing microfine titanium dioxide as physical UV filter. Int J Cosmet Sci 2000, 22:271-283.

70. Sagawa Y, Futakuchi M, Xu J, Fukamachi K, Sakai Y, Ikarashi Y, Nishimura T, Suzui M, Tsuda H, Morita A: Lack of promoting effect of titanium dioxide particles on chemically-induced skin carcinogenesis in rats and mice. J Toxicol Sci 2012, 37:317-327

71. Xu J, Sagawa Y, Futakuchi M, Fukamachi K, Alexander DB, Furukawa F, Ikarashi Y, Uchino T, Nishimura T, Morita A, et al: Lack of promoting effect of titanium dioxide particles on ultraviolet B-initiated skin carcinogenesis in rats. Food Chem Toxicol 2011, 49:1298-1302.

72. Monteiro-Riviere NA, Wiench K, Landsiedel R, Schulte S, Inman AO, Riviere JE: Safety evaluation of sunscreen formulations containing titanium dioxide and zinc oxide nanoparticles in UVB sunburned skin: an in vitro and in vivo study. Toxicol Sci 2011, 123:264-280

73. Miquel-Jeanjean C, Crepel F, Raufast V, Payre B, Datas L, Bessou-Touya S, Duplan H: Penetration Study of Formulated Nanosized Titanium Dioxide in Models of Damaged and Sun-Irradiated Skins. Photochem Photobiol 2012, 88:1513-1521.

74. Filipe P, Silva JN, Silva R, Cirne de Castro JL, Marques Gomes M, Alves LC, Santus $\mathrm{R}$, Pinheiro T: Stratum corneum is an effective barrier to $\mathrm{TiO} 2$ and $\mathrm{ZnO}$ nanoparticle percutaneous absorption. Skin Pharmacol Physiol 2009, 22:266-275.

75. Simko M, Mattsson MO: Risks from accidental exposures to engineered nanoparticles and neurological health effects: a critical review. Part Fibre Toxicol 2010, 7:42

76. Kuempel ED, Tran CL, Castranova V, Bailer AJ: Lung dosimetry and risk assessment of nanoparticles: evaluating and extending current models in rats and humans. Inhal Toxicol 2006, 18:717-724.

77. Muhlfeld C, Geiser M, Kapp N, Gehr P, Rothen-Rutishauser B: Reevaluation of pulmonary titanium dioxide nanoparticle distribution using the "relative deposition index": Evidence for clearance through microvasculature. Part Fibre Toxicol 2007, 4:7.

78. Driscoll KE, Costa DL, Hatch G, Henderson R, Oberdorster G, Salem $H$, Schlesinger RB: Intratracheal instillation as an exposure technique for the evaluation of respiratory tract toxicity: uses and limitations. Toxicol Sci 2000, 55:24-35.

79. Li Y, Li J, Yin J, Li W, Kang C, Huang Q, Li Q: Systematic influence induced by $3 \mathrm{~nm}$ titanium dioxide following intratracheal instillation of mice. J Nanosci Nanotechnol 2010, 10:8544-8549.

80. Wang J, Liu Y, Jiao F, Lao F, Li W, Gu Y, Li Y, Ge C, Zhou G, Li B, et al: Timedependent translocation and potential impairment on central nervous system by intranasally instilled $\mathrm{TiO}(2)$ nanoparticles. Toxicology 2008 , 254:82-90

81. Wang J, Chen C, Liu Y, Jia F, Li W, Lao F, Lia Y, Lia B, Ge C, Zhou G, et al: Potential neurological lesion after nasal instillation of $\mathrm{TiO}_{2}$ nanoparticles in the anatase and rutile crystal phases. Toxicol Lett 2008, 183:72-80

82. Deng ZJ, Mortimer G, Schiller T, Musumeci A, Martin D, Minchin RF: Differential plasma protein binding to metal oxide nanoparticles. Nanotechnology 2009, 20:455101.

83. Cedervall T, Lynch I, Lindman S, Berggard T, Thulin E, Nilsson H, Dawson KA, Linse S: Understanding the nanoparticle-protein corona using methods to quantify exchange rates and affinities of proteins for nanoparticles. Proc Natl Acad Sci U S A 2007, 104:2050-2055.

84. Mikkelsen L, Sheykhzade M, Jensen KA, Saber AT, Jacobsen NR, Vogel U, Wallin $\mathrm{H}$, Loft $\mathrm{S}$, Moller P: Modest effect on plaque progression and vasodilatory function in atherosclerosis-prone mice exposed to nanosized TiO(2). Part Fibre Toxicol 2011, 8:32.

85. Rothen-Rutishauser BM, Schurch S, Haenni B, Kapp N, Gehr P: Interaction of fine particles and nanoparticles with red blood cells visualized with advanced microscopic techniques. Environ Sci Technol 2006, 40:4353-4359.
86. Geiser M: Update on macrophage clearance of inhaled micro- and nanoparticles. J Aerosol Med Pulm Drug Deliv 2010, 23:207-217.

87. Wick P, Malek A, Manser P, Meili D, Maeder-Althaus X, Diener L, Diener PA, Zisch A, Krug HF, von Mandach U: Barrier capacity of human placenta for nanosized materials. Environ Health Perspect 2010, 118:432-436

88. Shimizu M, Tainaka H, Oba T, Mizuo K, Umezawa M, Takeda K: Maternal exposure to nanoparticulate titanium dioxide during the prenatal period alters gene expression related to brain development in the mouse. Part Fibre Toxicol 2009, 6:20.

89. Takeda K, Suzuki K, Ishihara A, Kubo-Irie M, Fujimoto R, Tabata M, Oshio S, Nihei Y, Ihara T, Sugamata M: Nanoparticles Transferred from Pregnant Mice to Their Offspring Can Damage the Genital and Cranial Nerve Systems. J Heal Sci 2009, 55:95-102.

90. Hougaard KS, Jackson P, Jensen KA, Sloth JJ, Loschner K, Larsen EH, Birkedal RK, Vibenholt A, Boisen AM, Wallin H, Vogel U: Effects of prenatal exposure to surface-coated nanosized titanium dioxide (UV-Titan). A study in mice. Part Fibre Toxicol 2010, 7:16.

91. Geiser M, Kreyling WG: Deposition and biokinetics of inhaled nanoparticles. Part Fibre Toxicol 2010, 7:2.

92. Eydner M, Schaudien D, Creutzenberg O, Ernst H, Hansen T, Baumgartner W, Rittinghausen S: Impacts after inhalation of nano- and fine-sized titanium dioxide particles: morphological changes, translocation within the rat lung, and evaluation of particle deposition using the relative deposition index. Inhal Toxicol 2012, 24:557-569.

93. Scherbart AM, Langer J, Bushmelev A, van Berlo D, Haberzettl P, van Schooten FJ, Schmidt AM, Rose CR, Schins RP, Albrecht C: Contrasting macrophage activation by fine and ultrafine titanium dioxide particles is associated with different uptake mechanisms. Part Fibre Toxicol 2011, 8:31

94. Ferin J, Oberdorster G, Penney DP: Pulmonary retention of ultrafine and fine particles in rats. Am J Respir Cell Mol Biol 1992, 6:535-542.

95. Churg A, Stevens B, Wright JL: Comparison of the uptake of fine and ultrafine TiO2 in a tracheal explant system. Am J Physiol 1998, 274:L81-86.

96. Chen J, Dong X, Zhao J, Tang G: In vivo acute toxicity of titanium dioxide nanoparticles to mice after intraperitioneal injection. J App/ Toxicol 2009, 29:330-337.

97. Liu H, Ma L, Zhao J, Liu J, Yan J, Ruan J, Hong F: Biochemical toxicity of nanoanatase TiO2 particles in mice. Biol Trace Elem Res 2009, 129:170-180.

98. Ma L, Liu J, Li N, Wang J, Duan Y, Yan J, Liu H, Wang H, Hong F: Oxidative stress in the brain of mice caused by translocated nanoparticulate $\mathrm{TiO} 2$ delivered to the abdominal cavity. Biomaterials 2010, 31:99-105.

99. World Health Organization (WHO): Environmental Health Criteria 24Titanium. In International Programme on Chemical Safety. Geneva: World Health Organization; 1982.

100. Huggins CB, Froehlich JP: High concentration of injected titanium dioxide in abdominal lymph nodes. J Exp Med 1966, 124:1099-1106.

101. Geiser M, Casaulta M, Kupferschmid B, Schulz H, Semmler-Behnke M, Kreyling $W$ : The role of macrophages in the clearance of inhaled ultrafine titanium dioxide particles. Am J Respir Cell Mol Biol 2008, 38:371-376.

102. Tang M, Zhang T, Xue Y, Wang S, Huang M, Yang Y, Lu M, Lei H, Kong L, Yuepu P: Dose dependent in vivo metabolic characteristics of titanium dioxide nanoparticles. J Nanosci Nanotechnol 2010, 10:8575-8583.

103. Ma-Hock L, Burkhardt S, Strauss V, Gamer AO, Wiench K, van Ravenzwaay B, Landsiedel R: Development of a short-term inhalation test in the rat using nano-titanium dioxide as a model substance. Inhal Toxicol 2009, 21:102-118.

104. Grassian VH, O'Shaughnessy PT, Adamcakova-Dodd A, Pettibone JM, Thorne PS: Inhalation exposure study of titanium dioxide nanoparticles with a primary particle size of 2 to $5 \mathrm{~nm}$. Environ Health Perspect 2007, 115:397-402.

105. Nurkiewicz TR, Porter DW, Hubbs AF, Cumpston JL, Chen BT, Frazer DG, Castranova V: Nanoparticle inhalation augments particle-dependent systemic microvascular dysfunction. Part Fibre Toxicol 2008, 5:1.

106. Nurkiewicz TR, Porter DW, Hubbs AF, Stone S, Moseley AM, Cumpston JL, Goodwill AG, Frisbee SJ, Perrotta PL, Brock RW, et al: Pulmonary particulate matter and systemic microvascular dysfunction. Res Rep Health Eff Inst 2011:3-48.

107. LeBlanc AJ, Cumpston JL, Chen BT, Frazer D, Castranova V, Nurkiewicz TR: Nanoparticle inhalation impairs endothelium-dependent vasodilation in subepicardial arterioles. J Toxicol Environ Health A 2009, 72:1576-1584.

108. Sun Q, Hong X, Wold LE: Cardiovascular effects of ambient particulate air pollution exposure. Circulation 2010, 121:2755-2765. 
109. Liu R, Yin L, Pu Y, Liang G, Zhang J, Su Y, Xiao Z, Ye B: Pulmonary toxicity induced by three forms of titanium dioxide nanoparticles via intra-tracheal instillation in rats. Prog Nat Sci 2009, 19:573-579.

110. Kobayashi N, Naya M, Endoh S, Maru J, Yamamoto K, Nakanishi J: Comparative pulmonary toxicity study of nano-TiO(2) particles of different sizes and agglomerations in rats: different short- and long-term post-instillation results. Toxicology 2009, 264:110-118.

111. Liu R, Zhang X, Pu Y, Yin L, Li Y, Liang G, Li X, Zhang J: Small-sized titanium dioxide nanoparticles mediate immune toxicity in rat pulmonary alveolar macrophages in vivo. J Nanosci Nanotechnol 2010, 10:5161-5169.

112. Liu R, Yin LH, Pu YP, Li YH, Zhang XQ, Liang GY, Li XB, Zhang J, Li YF, Zhang $X Y$ : The immune toxicity of titanium dioxide on primary pulmonary alveolar macrophages relies on their surface area and crystal structure. J Nanosci Nanotechnol 2010, 10:8491-8499.

113. Hussain S, Vanoirbeek JA, Luyts K, De Vooght V, Verbeken E, Thomassen LC, Martens JA, Dinsdale D, Boland S, Marano F, et al: Lung exposure to nanoparticles modulates an asthmatic response in a mouse model. Eur Respir J 2011, 37:299-309.

114. Warheit DB, Hoke RA, Finlay C, Donner EM, Reed KL, Sayes CM: Development of a base set of toxicity tests using ultrafine $\mathrm{TiO} 2$ particles as a component of nanoparticle risk management. Toxicol Lett 2007, 171:99-110.

115. Liu Q, Hong Z, Guo B, Zhang Y, Li Y, Liu J: Experimental Study on Toxicity of Nanosized Titanium Dioxide. Mod Preventive Med 2006, 33:1211-1212.

116. Unnithan J, Rehman MU, Ahmad FJ, Samim M: Aqueous synthesis and concentration-dependent dermal toxicity of $\mathrm{TiO} 2$ nanoparticles in Wistar rats. Biol Trace Elem Res 2011, 143:1682-1694.

117. Ma L, Zhao J, Wang J, Liu J, Duan Y, Liu H, Li N, Yan J, Ruan J, Wang H, Hong F: The Acute Liver Injury in Mice Caused by Nano-Anatase TiO2. Nanoscale Res Lett 2009, 4:1275-1285.

118. Chen EY, Garnica M, Wang YC, Mintz AJ, Chen CS, Chin WC: A mixture of anatase and rutile $\mathrm{TiO}(2)$ nanoparticles induces histamine secretion in mast cells. Part Fibre Toxicol 2012, 9:2

119. Li SQ, Zhu RR, Zhu H, Xue M, Sun XY, Yao SD, Wang SL: Nanotoxicity of TiO (2) nanoparticles to erythrocyte in vitro. Food Chem Toxicol 2008 46:3626-3631

120. Aisaka $Y$, Kawaguchi R, Watanabe $\mathrm{S}$, Ikeda M, Igisu H: Hemolysis caused by titanium dioxide particles. Inhal Toxicol 2008, 20:891-893.

121. Zhang J, Song W, Guo J, Sun Z, Li L, Ding F, Gao M: Cytotoxicity of different sized $\mathrm{TiO} 2$ nanoparticles in mouse macrophages. Toxicol Ind Health 2012. http://tih.sagepub.com/content/early/2012/04/16/ 0748233712442708.abstract.

122. Qi K, Deng FR, Guo XB: [Effects of nanoscale titanium dioxide on intercellular gap junction communication in human lung fibroblasts]. Beijing Da Xue Xue Bao 2009, 41:297-301.

123. Rossi EMPL, Koivisto AJ, Vippopa M, Jensen KA, Miettinen M, Sirola K, Nykasenoja H, Karisola P, Stjernvall T, Vanhala E, Kiilunen M, Pasanen P, Makinen M, Hameri K, Joutsensaari J, Tuomi T, Jokiniemi J, Wolff H, Savolainen K, Matikainen S, Alenius H: Airway Exposure to Silica-Coated TiO2 Nanoparticles Induces Pulmonary Neutrophilia in Mice. Toxicol Sci 2010, 113:422-433.

124. Zhang Y, Tao J, He P, Tang Y, Wang Y: Bio-effects of nano-TiO2 on lungs of mice. Sheng Wu Yi Xue Gong Cheng Xue Za Zhi 2009, 26:803-806.

125. Oberdorster G, Finkelstein JN, Johnston C, Gelein R, Cox C, Baggs R, Elder $A C$ : Acute pulmonary effects of ultrafine particles in rats and mice. Res Rep Health Eff Inst 2000, 95:5-74.

126. Hu JQ, Chen CY, Bai R, Zhen S, Du XM, Zang JJ, Li JC, Gu YQ, Jia G: [Effect of nano-TiO(2) intratracheal instillation on lipid metabolism of AopE gene-knockout mice]. Zhonghua Yu Fang Yi Xue Za Zhi 2010, 44:780-784.

127. Larsen ST, Roursgaard M, Jensen KA, Nielsen GD: Nano titanium dioxide particles promote allergic sensitization and lung inflammation in mice. Basic Clin Pharmacol Toxicol 2010, 106:114-117.

128. Bu Q, Yan G, Deng P, Peng F, Lin H, Xu Y, Cao Z, Zhou T, Xue A, Wang Y, et al: NMR-based metabonomic study of the sub-acute toxicity of titanium dioxide nanoparticles in rats after oral administration. Nanotechnology 2010, 21:125105.

129. Bermudez E, Mangum JB, Wong BA, Asgharian B, Hext PM, Warheit DB, Everitt Jl: Pulmonary responses of mice, rats, and hamsters to subchronic inhalation of ultrafine titanium dioxide particles. Toxicol Sci 2004, 77:347-357.
130. Warheit DB, Webb TR, Sayes CM, Colvin VL, Reed KL: Pulmonary instillation studies with nanoscale $\mathrm{TiO} 2$ rods and dots in rats: toxicity is not dependent upon particle size and surface area. Toxicol Sci 2006, 91:227-236.

131. Roursgaard M, Jensen KA, Poulsen SS, Jensen NE, Poulsen LK, Hammer M, Nielsen GD, Larsen ST: Acute and subchronic airway inflammation after intratracheal instillation of quartz and titanium dioxide agglomerates in mice. Sci World J 2011, 11:801-825.

132. Wang JX, Li YF, Zhou GQ, Li B, Jiao F, Chen CY, Gao YX, Zhao YL, Chai ZF: [Influence of intranasal instilled titanium dioxide nanoparticles on monoaminergic neurotransmitters of female mice at different exposure time]. Zhonghua Yu Fang Yi Xue Za Zhi 2007, 41:91-95.

133. Wu J, Liu W, Xue C, Zhou S, Lan F, Bi L, Xu H, Yang X, Zeng FD: Toxicity and penetration of $\mathrm{TiO} 2$ nanoparticles in hairless mice and porcine skin after subchronic dermal exposure. Toxicol Lett 2009, 191:1-8.

134. Hu R, Gong X, Duan Y, Li N, Che Y, Cui Y, Zhou M, Liu C, Wang H, Hong F: Neurotoxicological effects and the impairment of spatial recognition memory in mice caused by exposure to $\mathrm{TiO} 2$ nanoparticles. Biomaterials 2010, 31:8043-8050.

135. Baskerville A, Fitzgeorge RB, Gilmour MI, Dowsett AB, Williams A, Featherstone AS: Effects of inhaled titanium dioxide dust on the lung and on the course of experimental Legionnaires' disease. $\mathrm{Br} J$ Exp Pathol 1988, 69:781-792.

136. Warheit DB, Yuen IS, Kelly DP, Snajdr S, Hartsky MA: Subchronic inhalation of high concentrations of low toxicity, low solubility particulates produces sustained pulmonary inflammation and cellular proliferation. Toxicol Lett 1996, 88:249-253.

137. Warheit DB, Hansen JF, Yuen IS, Kelly DP, Snajdr SI, Hartsky MA: Inhalation of high concentrations of low toxicity dusts in rats results in impaired pulmonary clearance mechanisms and persistent inflammation. Toxicol Appl Pharmacol 1997, 145:10-22.

138. Bermudez E, Mangum JB, Asgharian B, Wong BA, Reverdy EE, Janszen DB, Hext PM, Warheit DB, Everitt Jl: Long-term pulmonary responses of three laboratory rodent species to subchronic inhalation of pigmentary titanium dioxide particles. Toxicol Sci 2002, 70:86-97.

139. Sang X, Zheng L, Sun Q, Li N, Cui Y, Hu R, Gao G, Cheng Z, Cheng J, Gui S, et al: The chronic spleen injury of mice following long-term exposure to titanium dioxide nanoparticles. J Biomed Mater Res A 2012, 100:894-902.

140. Lu PJ, Ho IC, Lee TC: Induction of sister chromatid exchanges and micronuclei by titanium dioxide in Chinese hamster ovary-K1 cells. Mutat Res 1998, 414:15-20.

141. IARC: Titanium dioxide. In IARC monographs on the evaluation of carcinogenic risks to humans, volume 47. Lyon; 1989:307-328.

142. Yazdi AS, Guarda G, Riteau N, Drexler SK, Tardivel A, Couillin I, Tschopp J: Nanoparticles activate the NLR pyrin domain containing 3 (NIrp3) inflammasome and cause pulmonary inflammation through release of IL-1alpha and IL-1beta. Proc Natl Acad Sci U S A 2010, 107:19449-19454.

143. Kan H, Wu Z, Young SH, Chen TH, Cumpston JL, Chen F, Kashon ML, Castranova V: Pulmonary exposure of rats to ultrafine titanium dioxide enhances cardiac protein phosphorylation and substance $P$ synthesis in nodose ganglia. Nanotoxicology 2011, 6:736-745.

144. Driscoll KE, Deyo LC, Carter JM, Howard BW, Hassenbein DG, Bertram TA: Effects of particle exposure and particle-elicited inflammatory cells on mutation in rat alveolar epithelial cells. Carcinogenesis 1997, 18:423-430.

145. Cui Y, Liu H, Zhou M, Duan Y, Li N, Gong X, Hu R, Hong M, Hong F: Signaling pathway of inflammatory responses in the mouse liver caused by TiO2 nanoparticles. J Biomed Mater Res A 2011, 96:221-229.

146. Gui S, Zhang Z, Zheng L, Cui Y, Liu X, Li N, Sang X, Sun Q, Gao G, Cheng Z, et al: Molecular mechanism of kidney injury of mice caused by exposure to titanium dioxide nanoparticles. J Hazard Mater 2011, 195:365-370.

147. Sun Q, Tan D, Ze Y, Sang X, Liu X, Gui S, Cheng Z, Cheng J, Hu R, Gao G, et al: Pulmotoxicological effects caused by long-term titanium dioxide nanoparticles exposure in mice. J Hazard Mater 2012, 235-236:47-53.

148. Li N, Duan Y, Hong M, Zheng L, Fei M, Zhao X, Wang J, Cui Y, Liu H, Cai J, et al: Spleen injury and apoptotic pathway in mice caused by titanium dioxide nanoparticules. Toxicol Lett 2010, 195:161-168.

149. Jackson P, Halappanavar S, Hougaard KS, Williams A, Madsen AM, Lamson JS, Andersen O, Yauk C, Wallin H, Vogel U: Maternal inhalation of surfacecoated nanosized titanium dioxide (UV-Titan) in C57BL/6 mice: effects in prenatally exposed offspring on hepatic DNA damage and gene expression. Nanotoxicology 2011, 7:85-96. 
150. Halappanavar S, Jackson P, Williams A, Jensen KA, Hougaard KS, Vogel U, Yauk $\mathrm{CL}$, Wallin $\mathrm{H}$ : Pulmonary response to surface-coated nanotitanium dioxide particles includes induction of acute phase response genes, inflammatory cascades, and changes in microRNAs: a toxicogenomic study. Environ Mol Mutagen 2011, 52:425-439.

151. Boisen AM, Shipley T, Jackson $\mathrm{P}$, Hougaard KS, Wallin H, Yauk CL, Vogel U: NanoTIO2 (UV-Titan) does not induce ESTR mutations in the germline of prenatally exposed female mice. Part Fibre Toxicol 2012, 9:19.

152. Lindberg HK, Falck GC, Catalan J, Koivisto AJ, Suhonen S, Jarventaus H, Rossi EM, Nykasenoja H, Peltonen Y, Moreno C, et al: Genotoxicity of inhaled nanosized TiO(2) in mice. Mutat Res 2012, 745:58-64.

153. Gallagher J, Heinrich U, George M, Hendee L, Phillips DH, Lewtas J: Formation of DNA adducts in rat lung following chronic inhalation of diesel emissions, carbon black and titanium dioxide particles. Carcinogenesis 1994, 15:1291-1299.

154. Zucker RM, Massaro EJ, Sanders KM, Degn LL, Boyes WK: Detection of TiO2 nanoparticles in cells by flow cytometry. Cytometry A 2010, 77:677-685.

155. Jugan ML, Barillet S, Simon-Deckers A, Herlin-Boime N, Sauvaigo S, Douki T, Carriere M: Titanium dioxide nanoparticles exhibit genotoxicity and impair DNA repair activity in A549 cells. Nanotoxicology 2012, 6:501-513.

156. Saquib Q, Al-Khedhairy AA, Siddiqui MA, Abou-Tarboush FM, Azam A, Musarrat J: Titanium dioxide nanoparticles induced cytotoxicity, oxidative stress and DNA damage in human amnion epithelial (WISH) cells. Toxicol In Vitro 2012, 26:351-361.

157. Bhattacharya K, Davoren M, Boertz J, Schins RP, Hoffmann E, Dopp E: Titanium dioxide nanoparticles induce oxidative stress and DNA-adduct formation but not DNA-breakage in human lung cells. Part Fibre Toxicol 2009, 6:17.

158. Bhattacharya $\mathrm{K}$, Cramer $\mathrm{H}$, Albrecht $\mathrm{C}$, Schins R, Rahman Q, Zimmermann U, Dopp E: Vanadium pentoxide-coated ultrafine titanium dioxide particles induce cellular damage and micronucleus formation in V79 cells. J Toxicol Environ Health A 2008, 71:976-980.

159. Morishige T, Yoshioka Y, Tanabe A, Yao X, Tsunoda S, Tsutsumi Y, Mukai Y, Okada N, Nakagawa S: Titanium dioxide induces different levels of IL1 beta production dependent on its particle characteristics through caspase- 1 activation mediated by reactive oxygen species and cathepsin B. Biochem Biophys Res Commun 2010, 392:160-165.

160. Vamanu Cl, Cimpan MR, Hol PJ, Sornes S, Lie SA, Gjerdet NR: Induction of cell death by $\mathrm{TiO} 2$ nanoparticles: studies on a human monoblastoid cell line. Toxicol In Vitro 2008, 22:1689-1696.

161. Wilhelmi V, Fischer U, van Berlo D, Schulze-Osthoff K, Schins RP, Albrecht C: Evaluation of apoptosis induced by nanoparticles and fine particles in RAW 264.7 macrophages: facts and artefacts. Toxicol In Vitro 2012, 26:323-334.

162. Kang SJ, Kim BM, Lee YJ, Hong SH, Chung HW: Titanium dioxide nanoparticles induce apoptosis through the JNK/p38-caspase-8-Bid pathway in phytohemagglutinin-stimulated human lymphocytes. Biochem Biophys Res Commun 2009, 386:682-687.

163. Shi $Y$, Wang F, He J, Yadav S, Wang H: Titanium dioxide nanoparticles cause apoptosis in BEAS-2B cells through the caspase 8/t-Bidindependent mitochondrial pathway. Toxicol Lett 2010, 196:21-27.

164. Kang SJ, Kim BM, Lee YJ, Chung HW: Titanium dioxide nanoparticles trigger p53-mediated damage response in peripheral blood lymphocytes. Environ Mol Mutagen 2008, 49:399-405.

165. Xue C, Liu W, Wu J, Yang X, Xu H: Chemoprotective effect of Nacetylcysteine (NAC) on cellular oxidative damages and apoptosis induced by nano titanium dioxide under UVA irradiation. Toxicol In Vitro 2011, 25:110-116.

166. Ghosh M, Bandyopadhyay M, Mukherjee A: Genotoxicity of titanium dioxide (TiO2) nanoparticles at two trophic levels: plant and human lymphocytes. Chemosphere 2010, 81:1253-1262.

167. Falck GC, Lindberg HK, Suhonen S, Vippola M, Vanhala E, Catalan J, Savolainen K, Norppa H: Genotoxic effects of nanosized and fine $\mathrm{TiO} 2$. Hum Exp Toxicol 2009, 28:339-352.

168. Mano SSKK, Sonezaki S, Taniguchi A: Effect of Polyethylene Glycol Modification of TiO2 Nanoparticles on Cytotoxicity and Gene Expressions in Human Cell Lines. Int J Mol Sci 2012, 13:3703-3717.

169. Gerloff K, Fenoglio I, Carella E, Kolling J, Albrecht C, Boots AW, Forster I, Schins RP: Distinctive toxicity of $\mathrm{TiO} 2$ rutile/anatase mixed phase nanoparticles on Caco-2 cells. Chem Res Toxicol 2012, 25:646-655.
170. Gurr JR, Wang AS, Chen $\mathrm{CH}$, Jan KY: Ultrafine titanium dioxide particles in the absence of photoactivation can induce oxidative damage to human bronchial epithelial cells. Toxicology 2005, 213:66-73.

171. Huang S, Chueh PJ, Lin YW, Shih TS, Chuang SM: Disturbed mitotic progression and genome segregation are involved in cell transformation mediated by nano-TiO2 long-term exposure. Toxicol Appl Pharmacol 2009, 241:182-194.

172. Rahman Q, Lohani M, Dopp E, Pemsel H, Jonas L, Weiss DG, Schiffmann D: Evidence that ultrafine titanium dioxide induces micronuclei and apoptosis in Syrian hamster embryo fibroblasts. Environ Health Perspect 2002, 110:797-800.

173. Guichard Y, Schmit J, Darne C, Gate L, Goutet M, Rousset D, Rastoix O, Wrobel R, Witschger O, Martin A, et al: Cytotoxicity and genotoxicity of nanosized and microsized titanium dioxide and iron oxide particles in Syrian hamster embryo cells. Ann Occup Hyg 2012, 56:631-644.

174. Di Virgilio AL, Reigosa M, Arnal PM, Fernandez Lorenzo De Mele M: Comparative study of the cytotoxic and genotoxic effects of titanium oxide and aluminium oxide nanoparticles in Chinese hamster ovary (CHO-K1) cells. J Hazard Mater 2010, 177:711-718.

175. Wang S, Hunter LA, Arslan Z, Wilkerson MG, Wickliffe JK: Chronic exposure to nanosized, anatase titanium dioxide is not cyto- or genotoxic to Chinese hamster ovary cells. Environ Mol Mutagen 2011, 52:614-622.

176. Setyawati MI, Khoo PK, Eng BH, Xiong S, Zhao X, Das GK, Tan TT, Loo JS, Leong DT, Ng KW: Cytotoxic and genotoxic characterization of titanium dioxide, gadolinium oxide, and poly (lactic-co-glycolic acid) nanoparticles in human fibroblasts. J Biomed Mater Res A 2012, 101:633-640.

177. Prasad RY, Chastain PD, Nikolaishvili-Feinberg N, Smeester L, Kaufmann WK, Fry RC: Titanium dioxide nanoparticles activate the ATM-Chk2 DNA damage response in human dermal fibroblasts. Nanotoxicology 2012 doi:10.3109/17435390.2012.710659.

178. Li N, Ma L, Wang J, Zheng L, Liu J, Duan Y, Liu H, Zhao X, Wang S, Wang H, et al: Interaction Between Nano-Anatase $\mathrm{TiO}(2)$ and Liver DNA from Mice In Vivo. Nanoscale Res Lett 2009, 5:108-115.

179. Wan R, Mo Y, Feng L, Chien S, Tollerud DJ, Zhang Q: DNA damage caused by metal nanoparticles: involvement of oxidative stress and activation of ATM. Chem Res Toxicol 2012, 25:1402-1411.

180. Aueviriyavit S, Phummiratch D, Kulthong K, Maniratanachote R: Titanium dioxide nanoparticles-mediated in vitro cytotoxicity does not induce hsp70 and grp78 expression in human bronchial epithelial a549 cells. Biol Trace Elem Res 2012, 149:123-132.

181. Woodruff RS, Li Y, Yan J, Bishop M, Jones MY, Watanabe F, Biris AS, Rice P Zhou T, Chen T: Genotoxicity evaluation of titanium dioxide nanoparticles using the Ames test and Comet assay. J Appl Toxicol 2012, 32:934-943.

182. Linnainmaa K, Kivipensas $P$, Vainio $H$ : Toxicity and cytogenetic studies of ultrafine titanium dioxide in cultured rat liver epithelial cells. Toxicol In Vitro 1997, 11:329-335.

183. Fisichella M, Berenguer F, Steinmetz G, Auffan M, Rose J, Prat O: Intestinal toxicity evaluation of $\mathrm{TiO} 2$ degraded surface-treated nanoparticles: a combined physico-chemical and toxicogenomics approach in caco-2 cells. Part Fibre Toxicol 2012, 9:18

184. Wilson D, Zagout M, Heo JH, Park EK, Oak CH, Ueno S: Nuclear factorkappa $\mathrm{B}$ is not involved in titanium dioxide-induced inflammation. J UOEH 2012, 34:183-191.

185. Yu M, Mo Y, Wan R, Chien S, Zhang X, Zhang Q: Regulation of plasminogen activator inhibitor-1 expression in endothelial cells with exposure to metal nanoparticles. Toxicol Lett 2010, 195:82-89.

186. Wan R, Mo Y, Zhang X, Chien S, Tollerud DJ, Zhang Q: Matrix metalloproteinase- 2 and -9 are induced differently by metal nanoparticles in human monocytes: The role of oxidative stress and protein tyrosine kinase activation. Toxicol Appl Pharmacol 2008, 233:276-285.

187. Wang J, Zhu X, Zhang X, Zhao Z, Liu H, George R, Wilson-Rawls J, Chang Y, Chen Y: Disruption of zebrafish (Danio rerio) reproduction upon chronic exposure to TiO nanoparticles. Chemosphere 2011, 83:461-467.

188. Zhu X, Zhu L, Duan Z, Qi R, Li Y, Lang Y: Comparative toxicity of several metal oxide nanoparticle aqueous suspensions to Zebrafish (Danio rerio) early developmental stage. J Environ Sci Health, Part A: Tox Hazard Subst Environ Eng 2008, 43:278-284.

189. Takeda K, Suzuki K, Ishihara A, Kubo-Irie M, Fujimoto R, Tabota M, Oshio S, Nihei Y, Ihara T, Sugamata M: Nanoparticles Transferred from Pregnent Mice to Their Offspring can Damage the Genital and Cranial Nerve Systems. J Health Sci 2009, 55:95-102 
190. Yamashita K, Yoshioka Y, Higashisaka K, Mimura K, Morishita Y, Nozaki M, Yoshida T, Ogura T, Nabeshi H, Nagano K, et al: Silica and titanium dioxide nanoparticles cause pregnancy complications in mice. Nat Nanotechnol 2011, 6:321-328

191. Komatsu T, Tabata M, Kubo-Irie M, Shimizu T, Suzuki K, Nihei Y, Takeda K: The effects of nanoparticles on mouse testis Leydig cells in vitro. Toxicol In Vitro 2008, 22:1825-1831.

192. Borm PJ, Schins RP, Albrecht C: Inhaled particles and lung cancer, part B: paradigms and risk assessment. Int J Cancer 2004, 110:3-14.

193. Trochimowicz HJ, Lee KP, Reinhardt CF: Chronic inhalation exposure of rats to titanium dioxide dust. J App/ Toxicol 1988, 8:383-385.

194. Heinrich UF R, Rittinghausen S, Creutzenberg O, Bellmann B, Koch W, Levsen K: Chronic inhalation exposure of Wistar rats and two different strains of mice to diesel engine exhaust, carbon black, and titanium dioxide. Inhal Toxicol 1995, 7:533-556.

195. Pott F, Roller M: Carcinogenicity study with nineteen granular dusts in rats. Eur J Oncol 2005, 10:249.

196. Rittinghausen S, Mohr U, Dungworth DL: Pulmonary cystic keratinizing squamous cell lesions of rats after inhalation/instillation of different particles. Exp Toxicol Pathol 1997, 49:433-446.

197. Bernard BK, Osheroff MR, Hofmann A, Mennear JH: Toxicology and carcinogenesis studies of dietary titanium dioxide-coated mica in male and female Fischer 344 rats. J Toxicol Environ Health 1990 29:417-429.

198. Boffetta P, Gaborieau V, Nadon L, Parent MF, Weiderpass E, Siemiatycki J: Exposure to titanium dioxide and risk of lung cancer in a populationbased study from Montreal. Scand J Work Environ Health 2001, 27:227-232.

199. Fryzek JP, Chadda B, Marano D, White K, Schweitzer S, McLaughlin JK, Blot WJ: A cohort mortality study among titanium dioxide manufacturing workers in the United States. J Occup Environ Med 2003, 45:400-409.

200. Boffetta P, Soutar A, Cherrie JW, Granath F, Andersen A, Anttila A, Blettner M, Gaborieau V, Klug SJ, Langard S, et al: Mortality among workers employed in the titanium dioxide production industry in Europe. Cancer Causes Control 2004, 15:697-706.

201. Suttiponparnit KJ, Sahu M, Suvachittanont S, Charinpanitkul T, Biswas P: Role of Surface Area, Primary Particle Size, and Crystal Phase on Titanium Dioxide Nanoparticle Dispersion Properties. Nanoscale Res Lett 2011, 6:27.

202. Baan RA: Carcinogenic hazards from inhaled carbon black, titanium dioxide, and talc not containing asbestos or asbestiform fibers: recent evaluations by an IARC Monographs Working Group. Inhal Toxicol 2007, 19(Suppl 1):213-228.

203. Waris $G$, Ahsan $H$ : Reactive oxygen species: role in the development of cancer and various chronic conditions. J Carcinog 2006, 5:14

204. Buechter DD: Free radicals and oxygen toxicity. Pharm Res 1988 5:253-260

205. Susin SA, Daugas E, Ravagnan L, Samejima K, Zamzami N, Loeffler M, Costantini P, Ferri KF, Irinopoulou T, Prevost MC, et al: Two distinct pathways leading to nuclear apoptosis. J Exp Med 2000, 192:571-580.

206. Freyre-Fonseca V, Delgado-Buenrostro NL, Gutierrez-Cirlos EB, CalderonTorres CM, Cabellos-Avelar T, Sanchez-Perez Y, Pinzon E, Torres I, MolinaJijon E, Zazueta C, et al: Titanium dioxide nanoparticles impair lung mitochondrial function. Toxicol Lett 2011, 202:111-119.

207. Jaeger A, Weiss DG, Jonas L, Kriehuber R: Oxidative stress-induced cytotoxic and genotoxic effects of nano-sized titanium dioxide particles in human HaCaT keratinocytes. Toxicology 2012, 296:27-36.

208. Sanders K, Degn LL, Mundy WR, Zucker RM, Dreher K, Zhao B, Roberts JE, Boyes WK: In vitro phototoxicity and hazard identification of nano-scale titanium dioxide. Toxicol Appl Pharmacol 2012, 258:226-236.

209. Yin JJ, Liu J, Ehrenshaft M, Roberts JE, Fu PP, Mason RP, Zhao B: Phototoxicity of nano titanium dioxides in $\mathrm{HaCaT}$ keratinocytesGeneration of reactive oxygen species and cell damage. Toxicol Appl Pharmacol 2012, 263:81-88

210. Yoo KC, Yoon CH, Kwon D, Hyun KH, Woo SJ, Kim RK, Lim EJ, Suh Y, Kim MJ Yoon $\mathrm{TH}$, Lee SJ: Titanium dioxide induces apoptotic cell death through reactive oxygen species-mediated Fas upregulation and Bax activation. Int J Nanomedicine 2012, 7:1203-1214.

211. Sun Q, Tan D, Zhou Q, Liu X, Cheng Z, Liu G, Zhu M, Sang X, Gui S, Cheng $J$, et al: Oxidative damage of lung and its protective mechanism in mice caused by long-term exposure to titanium dioxide nanoparticles. J Biomed Mater Res A 2012, 100:2554-2562.
212. Liu S, Xu L, Zhang T, Ren G, Yang Z: Oxidative stress and apoptosis induced by nanosized titanium dioxide in PC12 cells. Toxicology 2010, 267:172-177.

213. Meena R, Rani M, Pal R, Rajamani P: Nano-TiO2-induced apoptosis by oxidative stress-mediated DNA damage and activation of p53 in human embryonic kidney cells. Appl Biochem Biotechnol 2012, 167:791-808.

214. Wu J, Sun J, Xue Y: Involvement of JNK and P53 activation in G2/M cell cycle arrest and apoptosis induced by titanium dioxide nanoparticles in neuron cells. Toxicol Lett 2010, 199:269-276.

215. Winter M, Beer HD, Hornung V, Kramer U, Schins RP, Forster l: Activation of the inflammasome by amorphous silica and $\mathrm{TiO} 2$ nanoparticles in murine dendritic cells. Nanotoxicology 2011, 5:326-340.

216. Wang J, Li N, Zheng L, Wang S, Wang Y, Zhao X, Duan Y, Cui Y, Zhou M, Cai J, et al: P38-Nrf-2 signaling pathway of oxidative stress in mice caused by nanoparticulate TiO2. Biol Trace Elem Res 2011, 140:186-197.

217. Uchino T, Tokunaga $H$, Ando $M$, Utsumi $H$ : Quantitative determination of $\mathrm{OH}$ radical generation and its cytotoxicity induced by $\mathrm{TiO}(2)-U V A$ treatment. Toxicol In Vitro 2002, 16:629-635.

218. Onuma K, Sato Y, Ogawara S, Shirasawa N, Kobayashi M, Yoshitake J, Yoshimura T, ligo M, Fujii J, Okada F: Nano-scaled particles of titanium dioxide convert benign mouse fibrosarcoma cells into aggressive tumor cells. Am J Pathol 2009, 175:2171-2183.

219. Toyooka T, Amano T, Ibuki Y: Titanium dioxide particles phosphorylate histone H2AX independent of ROS production. Mutat Res 2012, 742:84-91

220. Moon C, Park HJ, Choi YH, Park EM, Castranova V, Kang JL: Pulmonary inflammation after intraperitoneal administration of ultrafine titanium dioxide (TiO2) at rest or in lungs primed with lipopolysaccharide. $J$ Toxicol Environ Health A 2010, 73:396-409.

221. Goncalves DM, Chiasson S, Girard D: Activation of human neutrophils by titanium dioxide (TiO2) nanoparticles. Toxicol In Vitro 2010, 24:1002-1008.

doi:10.1186/1743-8977-10-15

Cite this article as: Shi et al:: Titanium dioxide nanoparticles: a review of current toxicological data. Particle and Fibre Toxicology 2013 10:15.

\section{Submit your next manuscript to BioMed Central and take full advantage of:}

- Convenient online submission

- Thorough peer review

- No space constraints or color figure charges

- Immediate publication on acceptance

- Inclusion in PubMed, CAS, Scopus and Google Scholar

- Research which is freely available for redistribution

Submit your manuscript at www.biomedcentral.com/submit
C) BioMed Central 